\title{
RESÍDUOS DE DELTAMETRINA, APLICADA EM DIFERENTES FORMULAÇÕES, EM COMPARTIMENTOS DA CULTURA DO PEPINO (Cucumis sativus L.) TUTORADO E AÇÃO DO INSETICIDA NO CONTROLE DA BROCA-DAS-CUCURBITÁCEAS Diaphania nitidalis (CRAMER, 1782) (LEPIDOPTERA:CRAMBIDAE)
}

\author{
ANDRÉ ANDRADE FRANCO
}

Tese apresentada à Escola Superior de Agricultura "Luiz de Queiroz", Universidade de São Paulo, para obtenção do título de Doutor em Ciências, Área de Concentração:Entomologia.

PIR A C I C A B A

Estado de São Paulo - Brasil

Julho - 2004 


\title{
RESÍDUOS DE DELTAMETRINA, APLICADA EM DIFERENTES FORMULAÇÕES, EM COMPARTIMENTOS DA CULTURA DO PEPINO (Cucumis sativus L.) TUTORADO E AÇÃO DO INSETICIDA NO CONTROLE DA BROCA-DAS-CUCURBITÁCEAS Diaphania nitidalis (CRAMER, 1782) (LEPIDOPTERA:CRAMBIDAE)
}

\author{
ANDRÉ ANDRADE FRANCO \\ Engenheiro Agrônomo
}

Orientador: Prof. Dr. GILBERTO CASADEI DE BAPTISTA

Tese apresentada à Escola Superior de
Agricultura "Luiz de Queiroz",
Universidade de São Paulo, para
obtenção do título de Doutor em
Ciências,
Concentração:Entomologia.

PIR A C I C A B A

Estado de São Paulo - Brasil

Julho - 2004 


\section{Dados Internacionais de Catalogação na Publicação (CIP) DIVISÃO DE BIBLIOTECA E DOCUMENTAÇÃO - ESALQ/USP}

\section{Franco, André Andrade}

Resíduos de deltametrina, aplicada em diferentes formulações, em compartimen-tos da cultura do pepino (Cucumis sativus L.) tutorado e ação do inseticida no controle da broca-das-cucurbitáceas Diaphania nitidalis (Cramer, 1782) (Lepidoptera: Crambidae) / André Andrade Franco. - - Piracicaba, 2004.

$110 \mathrm{p}$.

Tese (doutorado) - - Escola Superior de Agricultura Luiz de Queiroz, 2004.

Bibliografia.

1. Brocas (Insetos nocivos) 2. Controle químico 3. Inseticidas piretróides 4. Pepino 5. Resíduos de pesticidas em plantas I. Título 


\section{Ao Professor com carinho.}

Mestre é aquele que caminha com o tempo, propondo paz, fazendo comunhão, despertando sabedoria.

Mestre é aquele que estende a mão, inicia o dialogo e encaminha para a aventura da vida.

Não é o ensina formulas, regras, raciocínio, mas o que questiona desperta para a realidade.

Não é aquele que dá de seu saber, mas aquele que faz germinar o saber do discípulo.

Mestre é você, professor amigo, que me compreende, me estimula e me enriquecem com sua presença, seu saber e sua ternura.

Eu serei sempre um seu discípulo na escola da vida.

(N. Maccari)

Aos meus pais, Maria José e Ademar e aos meus irmãos, Inácio, Gustavo, Eugênio, Ademar e aos meus sobrinhos, Jade, Camila, Mariana, Thiago. 


\section{AGRADECIMENTOS}

A Escola Superior de Agricultura "Luiz de Queiroz" (ESALQ/USP), pela oportunidade concedida para a realização deste trabalho.

A Coordenação de Aperfeiçoamento de Pessoal de Nível Superior (CAPES), pela concessão da bolsa de estudos.

Ao Prof. Dr. Gilberto Casadei de Baptista, pela amizade, apoio e orientação.

Ao Dr. Luiz Roberto Pimentel Trevizan pela inestimável ajuda, amizade, confiança e apoio durante todo o trabalho.

Ao amigo $\mathrm{Eng}^{\circ}$ Florestal Ricardo Eugênio Cassamassimo pelo auxílio durante todo o trabalho

A todos os professores do Setor de Entomologia, pelos ensinamentos recebidos.

Aos colegas do Programa de Pós-Graduação em Entomologia, especialmente, Rita, Uemerson Cunha e Luciano Pacelli, Cruz, e demais amigos em todos os momentos.

Ao Eng $^{\circ}$ Agr $^{\circ}$ Renato Agnelo da Silva pela concessão da área para montagem do campo experimental.

Aos amigos do Laboratório de Resíduos de Pesticidas, do Departamento de Entomologia, Fitopatologia e Zoologia Agrícola, da ESALQ/USP, Aline, Adriana, Matheus, Juvenal, Carolina, Rosinês, Luís Ricardo, João Henrique, Abel, Jefersson, Gabriela, Javier, Oscar Bahia, Stella, André Reis, Flávia, Ricardo Armengol e Paulo Cezar pela ajuda inestimável e convívio.

Ao colega Carlos Eduardo Longatti, pelo apoio e inestimável amizade.

Aos funcionários da Biblioteca Central da ESALQ/USP, pelo auxílio na elaboração deste trabalho

A todos que contribuíram de alguma forma, manifesto os meus mais sinceros agradecimentos. 


\section{SUMÁRIO}

LISTA DE FIGURAS ......................................................................... vii

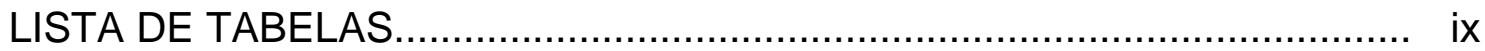

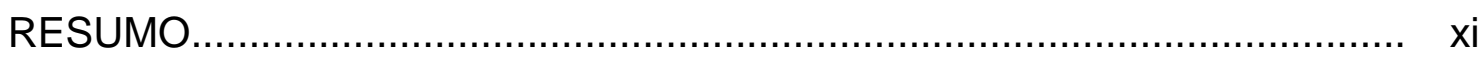

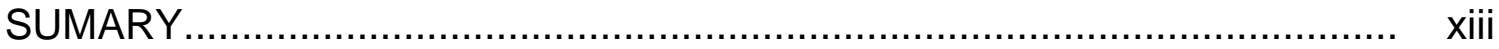

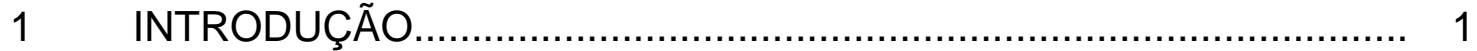

2 REVISÃO DE LITERATURA........................................................ 4

2.1 Considerações acerca do estudo de resíduos de agrotóxicos............. 4

2.2 Resíduos de agrotóxicos em hortaliças............................................ 9

2.3 Resíduos de inseticidas piretróides no solo....................................... 13

$2.4 \quad$ Resíduos deslocáveis............................................................ 17

2.4.1 A contaminação do homem por agrotóxicos..................................... 17

2.4.2 Resíduos deslocáveis em algumas culturas................................... 19

2.4.3 Fatores que determinam exposição aos agrotóxicos.......................... 22

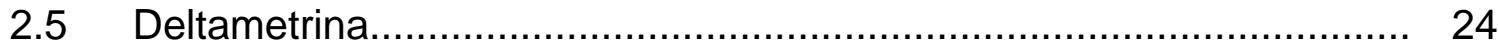

2.6 Descrição, importância e controle da broca-das-cucurbitáceas........... 27

3 MATERIAL E MÉTODOS ......................................................... 30

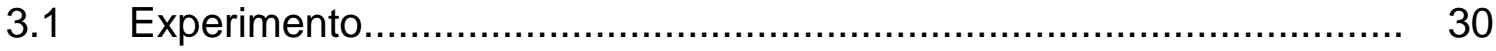

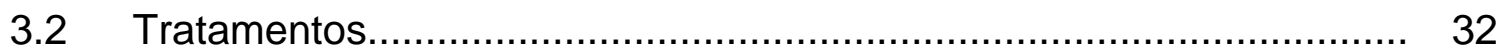

3.3 Amostragens..................................................................... 32 
3.4 Limites de quantificação, porcentagens de recuperação e descrição do método de análises de resíduos de deltametrina em amostras de fruto, folha, solo e resíduos deslocáveis.

3.5 Método para análise de resíduo de deltametrina em fruto, folha, solo e resíduos deslocáveis 34

3.5.1 Fruto e folha. 34

3.5.2 Solo. 41

3.5.3 Resíduos deslocáveis em folhas. 42

3.6 Avaliação da infestação da broca-das-cucurbitáceas. 46

4 RESULTADOS E DISCUSSÃO. 47

4.1 Limites de quantificação e porcentagens de recuperação dos métodos de analises de resíduos de deltametrina em amostras de fruto, folha, solo e resíduos deslocáveis.

4.2 Resíduos de deltametrina em frutos............................................... 53

4.3 Resíduos de deltametrina em folhas................................................ 57

4.4 Resíduos de deltametrina no solo.................................................... 61

4.5 Resíduos deslocáveis de deltametrina em folhas............................. 65

4.6 Ação de deltametrina no controle da broca-das-cucurbitáceas............ 73

5 CONCLUSÕES........................................................................ 77

REFERÊNCIAS BIBLIOGRAFICAS ................................................. 79

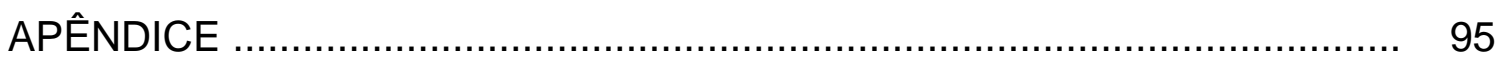




\section{LISTA DE FIGURAS}

1 Curvas de degradação e persistência idealizadas e ilustrativas, para inseticidas não sistêmicos sobre e no interior de cascas de laranjas............ 5

2 Fórmula estrutural da deltametrina......................................................... 24

3 Cromatograma de padrão (deltametrina).............................................. 49

4 Cromatograma de amostra testemunha (fruto) de pepino....................... 49

5 Cromatograma de extrato de fruto / fortificação deltametrina................... 49

6 Cromatograma de padrão (deltametrina)............................................. 50

7 Cromatograma de amostra testemunha (folha) de pepino...................... 50

8 Cromatograma de extrato de folha / fortificação deltametrina................... 50

9 Cromatograma de padrão (deltametrina).............................................. 51

10 Cromatograma de amostra testemunha (solo) de pepino...................... 51

11 Cromatograma de extrato de solo / fortificação deltametrina.................. 52

12 Cromatograma de padrão (deltametrina)......................................... 52

13 Cromatograma de amostra testemunha de folhas (resíduo deslocável)

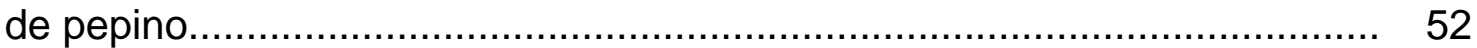

14 Cromatograma de extrato de folhas (resíduo deslocável) de pepino / fortificação deltametrina....................................................................... 53

15 Resíduos de deltametrina em cultura de pepino (fruto)......................... 55

16 Cromatogramas de extratos de amostras de fruto em diferentes

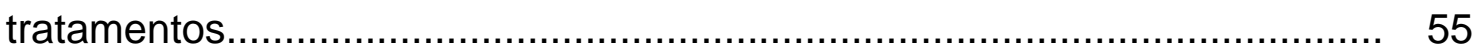

17 Resíduos de deltametrina em cultura de pepino (folha)....................... 59 
18 Cromatogramas de extratos de amostras de folha de diferentes

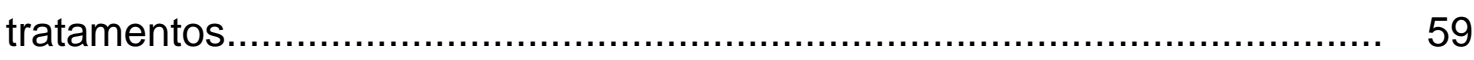

19 Resíduos de deltametrina em cultura de pepino (solo)......................... 63

20 Cromatogramas de extratos de solo cultivados com pepino de diferentes tratamentos

21 Resíduos de deltametrina em cultura de pepino (folhas - resíduo deslocável).

22 Cromatograma de amostra tratamento $25 \mathrm{~g}$ i.a. $100 \mathrm{~L}^{-1} \mathrm{em}$ folha (resíduo deslocável) - (deltametrina - Decis $25 \mathrm{CE}$ )

23 Cromatograma de amostra tratamento 100 g i.a. $100 \mathrm{~L}^{-1} \mathrm{em}$ folha (resíduo deslocável) - (deltametrina - Decis Ultra 100 CE)

24 Cromatograma de amostra tratamento 200 g i.a. $100 \mathrm{~L}^{-1} \mathrm{em}$ folha (resíduo deslocável) - (deltametrina - Decis 200 SC).

25Resíduo deslocável de deltametrina em folhas de pepino, aplicação de Decis 25 CE $\left(\right.$ ng. $\left.\mathrm{cm}^{-2}\right)$.

26 Resíduo deslocável de deltametrina em folhas de pepino, aplicação de Decis Ultra 100 CE $\left(\mathrm{ng} . \mathrm{cm}^{-2}\right)$.....

27 Resíduo deslocável de deltametrina em folhas de pepino, aplicação de Decis Ultra 100 CE $\left(\mathrm{ng} . \mathrm{cm}^{-2}\right)$. 


\section{LISTA DE TABELAS}

1 Propriedades físicas e químicas da deltametrina................................... 25

2 Porcentagens (\%) de recuperação de resíduos de deltametrina em

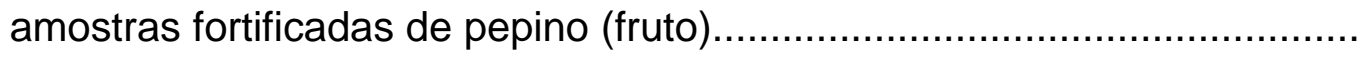

3 Porcentagens (\%) de recuperação de resíduos de deltametrina em

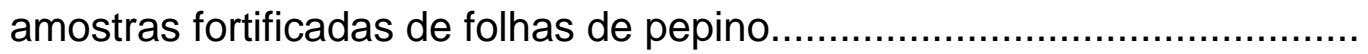

4 Porcentagens (\%) de recuperação de resíduos de deltametrina em amostras fortificadas de solo cultivado com pepino................................ 48

5 Porcentagens (\%) de recuperação de resíduos de deltametrina em amostras fortificadas de folha para resíduos deslocáveis

6 Resíduos de deltametrina de diferentes formulações em frutos de

pepino.

7 Resíduos de deltametrina de diferentes formulações em folhas de pepino.

8 Resíduos de deltametrina de diferentes formulações em solo sob cultivo de pepino.

9 Resíduos deslocáveis de deltametrina de diferentes formulações em folhas de pepino.

10 Valores de depósito inicial (Qo), constante do tempo (K) e coeficiente de correlação $\left(R^{2}\right)$, estimados por regressão não linear para os tratamentos para as amostras de folhas.....

11 Avaliação da infestação de $D$. nitidalis em pepino (-1 dia após a última aplicação).... 
12 Avaliação da infestação de $D$. nitidalis em pepino (zero dia após a última aplicação)

13 Avaliação da infestação de $D$. nitidalis em pepino (1 dia após a última aplicação).

14 Avaliação da infestação de $D$. nitidalis em pepino (3 dias após a última aplicação).

15 Avaliação da infestação de $D$. nitidalis em pepino (5 dias após a última aplicação) 75 16 Avaliação da infestação de $D$. nitidalis em pepino (7 dias após a última aplicação) 75 


\title{
RESÍDUOS DE DELTAMETRINA, APLICADA EM DIFERENTES FORMULAÇÕES, EM COMPARTIMENTOS DA CULTURA DO PEPINO (Cucumis sativus L.) TUTORADO E AÇÃO DO INSETICIDA NO CONTROLE DA BROCA-DAS-CUCURBITÁCEAS Diaphania nitidalis (CRAMER, 1782) (LEPIDOPTERA:CRAMBIDAE)
}

\author{
Autor: ANDRÉ ANDRADE FRANCO \\ Orientador: Prof. Dr. GILBERTO CASADEI DE BAPTISTA
}

RESUMO

O desenvolvimento da agricultura, a modernização dos meios dos cultivos, buscando atender a um mercado exigente, tem-se baseado no uso de insumos agrícolas para garantir a produção de alta qualidade e de quantidade. Tais culturas demandam o uso de pesticidas, cujos resíduos, principalmente em hortaliças e frutas, são motivo de preocupação com a saúde dos consumidores e de operários que necessitam retornar às culturas tratadas com esses agrotóxicos. Os objetivos deste estudo foram: a) estudar o comportamento dos resíduos de deltametrina, de diferentes formulações, em frutos, folhas e solo; b) avaliar os resíduos deslocáveis do inseticida nas folhas, como ponto de partida para estudos de exposição ocupacional; c) correlacionar os teores de deltametrina nos frutos com o controle da broca-das-cucurbitáceas e d) correlacionar os resíduos nos frutos com o limite máximo de resíduo (LMR) e o intervalo de segurança (período de carência) estabelecidos pela legislação. Os tratamentos foram: a) testemunha; b) três aplicações da formulação em 
concentrado emulsionável Decis $25 \mathrm{CE}$ na dosagem de $30 \mathrm{~mL}$ p.c.100 $\mathrm{L}^{-1}$ de água $\left(0,75 \mathrm{~g}\right.$ i.a. deltametrina. $100 \mathrm{~L}^{-1}$ de água); c) três aplicações da formulação em concentrado emulsionável Decis Ultra $100 \mathrm{CE}$ na dosagem de 7,5 mL p.c.100 $\mathrm{L}^{-1}$ de água (0,75 g i.a. deltametrina.100 $\mathrm{L}^{-1}$ de água); e d) três aplicações da formulação em suspensão concentrada Decis 200 SC na dosagem de $3,75 \mathrm{~mL}$ de p.c. $100 \mathrm{~L}^{-1}$ de água $\left(0,75 \mathrm{~g}\right.$ i.a. deltametrina $100 \mathrm{~L}^{-1} \mathrm{de}$ água). As amostras de fruto e de solo foram colhidas a (-1); zero; $1 ; 3 ; 5$ e 7 dias após a última aplicação; as amostras de folhas e as de para estudos de resíduos deslocáveis nestas foram tomadas a (-1); zero; 1; 3; 5; 7 e 14 dias. 0 método analítico constou da extração dos resíduos de deltametrina de acetato de etila, limpeza dos extratos por técnica de cromatografia de permeação em gel (GPC), com eluição feita com uma mistura de acetato de etila/ciclohexano. A determinação quantitativa por cromatografia de gás. Para a avaliação da eficiência do inseticida, foram feitas seis levantamentos de infestação, determinando-se a porcentagem de frutos brocados. Os resultados indicaram que os resíduos de deltametrina no fruto, embora em baixos níveis, encontravam-se acima do $\operatorname{LMR}\left(0,03 \mathrm{mg} \cdot \mathrm{kg}^{-1}\right)$, mesmo um dia após o término do intervalo de segurança (2 dias) para as formulações do inseticida. Nas folhas, os resíduos resultantes das aplicações da formulação SC foram sempre maiores do que ambas CE (10-20 vezes), sendo de 15-80 vezes mais altas do que nos frutos. No solo, os resíduos foram também baixos $\left(0,01-0,05 \mathrm{mg} \cdot \mathrm{kg}^{-1}\right)$, e semelhantes nas três formulações, entretanto, com baixa dissipação. Os resíduos deslocáveis de deltametrina nas folhas foram muito elevados quando de aplicações em SC, comparadas com as formulações CE (4-20 vezes), com valores de meias-vida de 2,8; 3,8 e 32,2 dias, respectivamente para as formulações Decis 25 CE, Decis Ultra 100 CE e Decis 200 SC. O inseticida, nas formulações em que foi aplicado, foi eficiente no controle da praga durante todo o período de avaliação. 


\title{
DELTAMETHRIN RESIDUES APPLIED IN DIFFERENT FORMULATIONS, IN STAKED CUCUMBER (Cucumis sativus L.) CROP COMPARTMENTS AND THE INSECTICIDE ACTION ON THE CONTROL OF THE PICKLEWORM, Diaphania nitidalis (CRAMER, 1782) (LEPIDOPTERA: CRAMBIDAE)
}

\author{
Author: ANDRÉ ANDRADE FRANCO \\ Adviser: Prof. Dr. GILBERTO CASADEI DE BAPTISTA
}

\section{SUMMARY}

The agriculture development, the modernization of cultivation means, trying to meet a demanding market, has been based on the use of agricultural supplies to assure a high quality and quantity production. Such crops demand the use of pesticides, whose residues, especially in fruit and vegetable production, raise worries about the consumers' health and of the workers who need to return to the treated crop with these pesticides. The objectives of this study were: a) to study the behavior of deltamethrin residues applied in different formulations in fruits, leaves and soil; b) to evaluate the dislodgeable residues of the insecticide in leaves, as a starting point for occupational exposure studies; c) to correlate deltamethrin concentration in fruit with the pickleworm control and d) to correlate residues in fruit with the maximum residue level (MRL) and the safety interval established by the legislation. The treatments were: a) control ; b) three applications of the emulsifiable concentrate formulation Decis 25 CE.100 ${ }^{-1}$ at the dosage of $30 \mathrm{~mL}$ of c.p. $100 \mathrm{~L}^{-1}$ water $\left(0.75 \mathrm{~g}\right.$ a.i. deltamethrin. $100 \mathrm{~L}^{-1}$ water); 
c) three applications of the emulsifiable formulation of Decis Ultra $100 \mathrm{CE}$ at the dosage of $7.5 \mathrm{~mL}$ of p.c.100 $\mathrm{L}^{-1}$ water $\left(0.75 \mathrm{~g}\right.$ a.i. deltamethrin.100. $\mathrm{L}^{-1}$ water) and d) three applications of the concentrate suspension formulation Decis 200 $\mathrm{SC}$ at the dosage of $3.75 \mathrm{~mL}$ of c.p. $100 . \mathrm{L}^{-1}$ water $\left(0.75 \mathrm{~g}\right.$ a.i. deltamethrin $100 \mathrm{~L}^{-1}$ water). The fruit and soil samples were taken at (-1); zero; $1 ; 3 ; 5$ and 7 days after the last application; leaf samples and also those for the studies of dislodgeable residues on them were collected at (-1); zero; $1 ; 3 ; 5 ; 7$ and 14 days after the last application. The analytical method consisted of the extraction of deltamethrin residues in ethyl acetate, clean-up of the extracts by gel permeation chromatography (GPC), with elutition made with a mixture of ethyl acetate/cyclohexane. The quantitative determination was made by gas chromatograph. To evaluate the insecticide efficacy six infestation surveys were carried out, based on the percentage of infested fruit . The results indicate that the deltamethrin residues in fruit, though in low levels, were found higher than the MRL $\left(0.03 \mathrm{mg}^{-\mathrm{kg}^{-1}}\right)$, for the three insecticide formulations, even a day after the end of the safety interval (2 days). In the leaves the resulting residues of the applications of SC formulation were always bigger than both CE (10-20 times), being 15-80 times higher in the fruits. In the soil, the residues were also low (0.01-0.05 mg kg-1), and similar in the three formulations, however with low dissipation. The dislodgeable residues of deltamethrin in leaves were higher in SC as compared to both CE (4-20 times), with half-life values of 2.8; 3.8 and 32.2 days, respectively for the formulation Decis $25 \mathrm{CE}$, Decis Ultra $100 \mathrm{CE}$ and Decis 200 SC. The insecticide in the formulations applied was efficient in the pest control during the whole evaluation period. 


\section{INTRODUÇÃO}

O aumento da população mundial e a diminuição do contingente rural, obrigou a uma rápida mudança nas técnicas agrícolas, na tentativa de se produzir alimentos em quantidades suficientes para se suprir as necessidades básicas da população humana.

O desenvolvimento obtido, permitiu em algumas regiões, um certo equilíbrio entre o crescimento populacional e a produção de alimentos; porém, para que esta harmonia se faça sentir em todas as áreas habitadas da Terra, muito ainda há que se produzir. Os agrotóxicos são indubitavelmente necessários para uma agricultura moderna, sendo um insumo importante para que os agricultores consigam aumentar e assegurar a sua produção agrícola. As autoridades mundiais estão convencidas de que os métodos de controle químico continuarão a desempenhar papel significativo nos programas de controle de pragas e doenças nas próximas décadas.

Todavia, mesmo usados de modo adequado os agrotóxicos deixam resíduos nos substratos alimentares, cujo significado depende do quanto eles estão presentes no alimento com possibilidades de implicação na saúde, ou até mesmo econômicas como nas exportações, pois sendo o Brasil extremamente dependente da receita cambial produzida pelos produtos agrícolas, a perda de credibilidade destes junto aos países importadores, tem trazido grandes preocupações ao nosso agronegócio.

Uma crescente atenção moral e científica esta sendo devotada para estudar os tipos e as quantidades destes agrotóxicos e seus produtos transformados, persistindo como resíduo nos alimentos. Estes estudos 
envolvem avaliação detalhadas das naturezas, magnitudes, os locais de resíduos persistentes e estabelecimento de limites máximos de resíduos (LMR) e intervalos de segurança (período de carência), pela legislação.

A importância da utilização dos pesticidas como um dos meios para a garantia da produção e produtividade e para a proteção das colheitas, a execução de pesquisas e um monitoramento constante de seu comportamento sobre os substratos e / ou meio ambiente nas condições brasileiras é necessária para orientar a ação governamental e a extensão rural quanto ao uso destes produtos, bem como informar corretamente a população acerca de seus efeitos adversos (Lucas, 1998).

Uma característica importante no uso desses agrotóxicos (desde sua descoberta com potencial no controle e até à comercialização), é que seu destino principal foi sempre voltado para as grandes culturas; porém no caso das hortaliças, apesar de apresentarem ciclo curto e, relativamente, pequena área de produção, esses agrotóxicos acabam sendo, de certa forma, adaptados à essas olerícolas.

As hortaliças apresentam um grande retorno financeiro por área, principalmente por que atualmente o consumidor muitas vezes exige uma "aparência comercial" do produto como se estivesse implícito que isso é garantia de um alimento saudável e de qualidade, mesmo sendo os produtos freqüentemente consumidos "in natura".

Dentre as hortaliças cultivadas, o pepino ocupa lugar de destaque pela sua importância e aceitação pela população em geral, na forma de salada e picles. Assim, em 2002 foram comercializadas no CEAGESP-SP cerca de 41.000 toneladas dessa cucurbitácea. (Agrianual, 2004).

A cultura do pepino apresenta muitos e sérios problemas fitossanitários, tais como doenças e pragas. Destas, as pragas mais importantes citam-se: pulgão (Aphis gossypii Glover, 1877 e Myzus persicae (Sulzer, 1776) (Hemiptera-Homoptera, Aphidae), mosca branca Bemisia tabaci (Genn., 1889) 
(Hemiptera-Heteroptera, Aleyrodidae), tripes Thips palmi Karny, 1925 (Thysanoptera, Thripidae), brocas-das-cucurbitáceas Diaphania nitidalis (Cramer, 1782) e Diaphania hyalinata (Linneu,1758) (Lepidoptera, Crambidae), mosca-das-frutas Anastrepha grandis (Macquart, 1845) (Diptera, Tephritidae), lagarta-rosca Agrotis ipsilon (Hufnagel, 1765) (Lepidoptera, Noctuidae), vaquinhas Diabrotica speciosa (Germar, 1824) (Coleoptera, Chrysomelidae) e Epilachna cacica (Guérin, 1842) (Coleoptera, Coccinellidae), cujo controle é normalmente realizado com o uso de inseticidas (Gallo et al., 2002).

São poucos os estudos conhecidos de resíduos de hortaliças no Brasil, especialmente os relacionados a parâmetros de segurança de aplicadores profissionalmente expostos.

Os objetivos deste estudo foram determinar resíduos do inseticida piretróide deltametrina e seu comportamento em uma cultura de pepino tutorada, de modo a abranger:

a) o estudo do comportamento dos resíduos de deltametrina, de diferentes formulações, em frutos, folhas e solo;

b) avaliação dos resíduos deslocáveis do inseticida nas folhas, como ponto de partida para estudos de exposição ocupacional;

c) correlação entre os teores de deltametrina nos frutos com o controle da broca-das-cucurbitáceas;

d) correlação, entre os resíduos nos frutos com o limite máximo de resíduo (LMR) e o intervalo de segurança (período de carência) estabelecidos pela legislação. 


\section{REVISÃO DE LITERATURA}

\subsection{Considerações acerca do estudo de resíduos de agrotóxicos}

Para que um agrotóxico seja recomendado, não basta que ele seja eficiente no controle de pragas, doenças ou plantas daninhas; ele deve ser seguro para os aplicadores em suas várias formulações e não deve deixar resíduos prejudiciais nas partes comestíveis das plantas, acima dos legalmente aceitos. Infelizmente, dados de resíduos não podem ser extrapolados de uma cultura ou dosagem para outra, sendo que os dados detalhados de resíduos são necessários para cada cultura, agrotóxico, formulação e dosagem (Ebeling, 1963).

Giannotti (1971) considera que o resíduo poderia ser interpretado, à primeira vista, como uma simples camada de agrotóxico que recobre as folhas, frutos, raízes, etc., das plantas depois da aplicação dos mesmos; tal camada, entretanto, deve ser considerada como depósito do material. Desde que esta camada venha a sofrer a ação dos fatores climáticos como chuva, sol, vento, etc., e o que fica absorvido em maior ou menor quantidade nas plantas é que deve ser considerado como resíduo.

Segundo Gunther (1969), os processos de degradação (ou dissipação) e de persistência geralmente seguem uma reação cinética de primeira ordem, permitindo dessa maneira, estabelecer uma relação linear entre o logaritmo do valor do resíduo (em ppm) e os intervalos de tempo decorridos desde o tratamento. 
Desde muito antes, Gunther \& Blinn (1955) consideraram que o período requerido para o desaparecimento de uma certa porcentagem de resíduos é independente da quantidade do depósito inicial; assim, a magnitude do depósito a uma certa data futura pode ser antecipada de acordo com a inclinação da curva ao tempo em que a extrapolação é feita. Isso é de grande importância, pois possibilita o conhecimento da data aproximada em que os resíduos alcançarão o LMR (ou tolerância).

Em geral, quando o tratamento é realizado com um inseticida em aplicação convencional de pulverização, uma parte do depósito inicial perde-se de maneira mais rápida do que o restante. Nesse caso, o logaritmo da quantidade de resíduos, em função do período de exposição, produz uma curva do tipo como a da Figura 1 (Gunther, 1969).

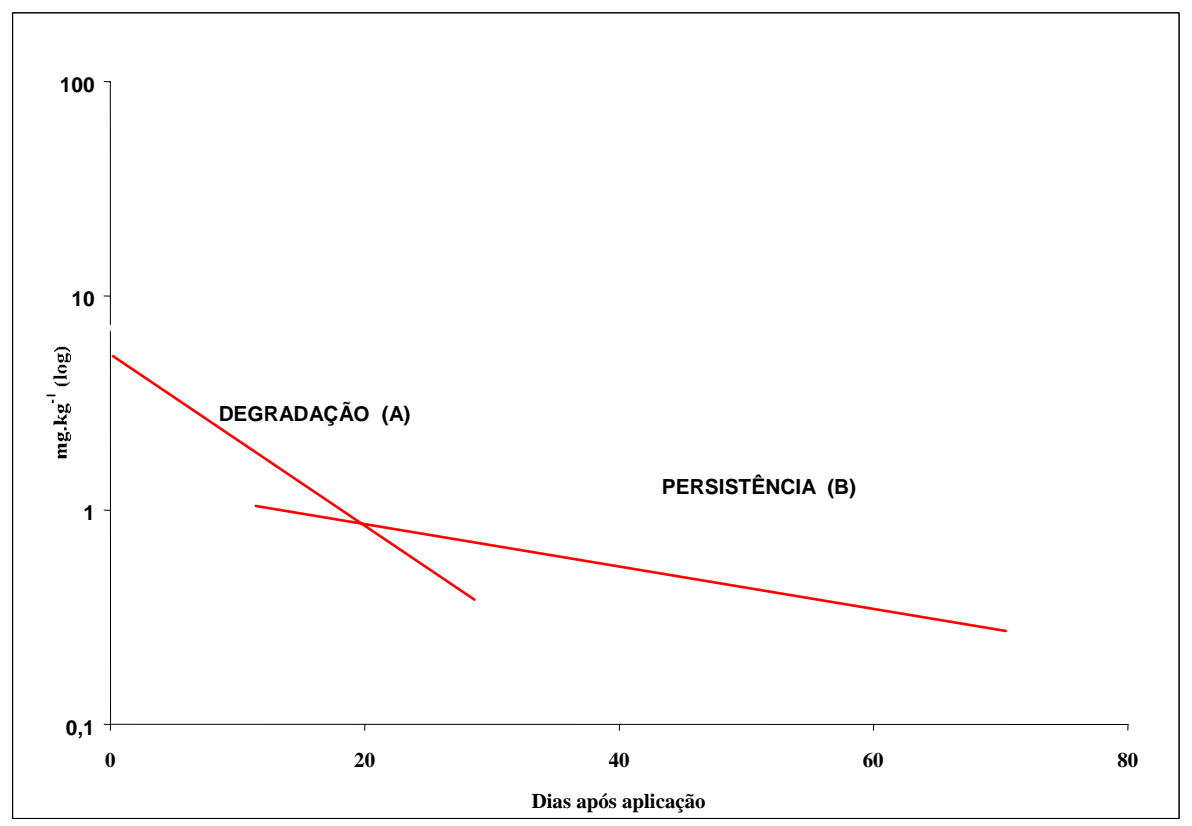

Figura 1 - Curvas de degradação e persistência idealizadas e ilustrativas, para inseticidas não sistêmicos sobre e no interior de cascas de laranjas (Gunther, 1969) 
Os segmentos de retas designados por A e $\mathbf{B}$ foram chamados pelo autor como curvas de degradação (dissipação) e de persistência, respectivamente. A porção $\mathrm{A}$ da curva representa uma rápida perda do depósito inicial dentro dos primeiros dias, como resultado da remoção do material não bem aderido à superfície vegetal principalmente pela ação dos ventos e das chuvas. A porção B da curva mostra uma maior dificuldade na remoção dos resíduos remanescentes, mais aderidos ao substrato vegetal; nesse caso a perda do resíduo é quase, exclusivamente, dependente dos fatores da planta, principalmente enzimas que promovem o metabolismo do produto, especialmente através de hidrólise, reação com grupos $\mathrm{SH}$, oxidação e outros (Gunther, 1969).

Devido ao envolvimento de reações de primeira ordem, o período de "meia-vida", RL 50, que é o tempo necessário para que haja desaparecimento da metade do resíduo, é independente da concentração inicial, e assim representa a característica de cada produto sobre ou dentro de um substrato particular. Para cada segmento (A e B) da Figura 1, tem-se uma meia-vida; estas são chamadas de meia-vida de degradação (dissipação), ou depósito para a porção A (curva de degradação ou dissipação) e meia-vida de persistência ou de resíduo para a porção B (curva de persistência) (Gunther, 1969). O autor ainda menciona que para um determinado produto e cultura, o valor de meia-vida de persistência é uma característica constante e utilizada em comparação de persistência (longevidade) de vários produtos e que as meiasvida, baseadas nas curvas de degradação (dissipação), são muito afetadas pelas variações das condições climáticas; assim, uma chuva no período de degradação (dissipação) irá deslocar para baixo ambas as curvas, podendo alterar a inclinação da curva de degradação (dissipação) mas não a de persistência.

Alguns agrotóxicos em certas plantas atingem LMR durante a fase de degradação (dissipação), enquanto que em outras plantas, os mesmos produtos atingem-na na fase de persistência (Ebeling, 1963). 
Dupuis (1975) afirma que a formulação pode afetar a taxa e o grau de penetração do produto ou a tenacidade do depósito superficial, sendo que a penetração do produto pode aumentar a degradação (dissipação) se o composto atingir o tecido sub-cuticular com alta atividade metabólica. Porém, se o mesmo permanecer na cutícula mais ou menos inerte na folha ou fruto, pode persistir por um longo período protegido das influências externas.

Alguns fatores que envolvem a degradação (dissipação) dos resíduos, são a taxa de crescimento e o tipo da planta, penetração, translocação, oxidação, temperatura, volatilização e hidrólise. Em plantas que apresentem um rápido crescimento, este é o fator mais importante na dissipação dos resíduos; os inseticidas do tipo p-nitrofenil-tionofosfatos não apresentam, ou apresentam pouca penetração e a hidrólise de seus oxons são muito mais rápidas do que seus respectivos tionofosfatos e, isto, talvez, seja a razão pela qual é difícil se encontrar oxons dos tionofosfatos (Coffin, 1964).

Rouchaud \& Meyer (1982) consideram que os agrotóxicos geralmente penetram nos tecidos da planta, mesmo que fracamente, sendo que os produtos que não penetram neles, permanecem na superfície da planta, sendo fotodecompostos, perdendo-se por volatilização e / ou lavagem pelas chuvas.

Quanto à penetração dos produtos, distinguem-se três categorias de resíduos: extracuticulares, cuticulares e sub-cuticulares. Os primeiros são aderentes à camada de cera; os segundos são os resíduos incrustrados ou dissolvidos nela e os últimos são aqueles presentes abaixo desta camada (Gunther \& Jeppson (1954) e Gunther \& Blinn (1955).

A formulação é um dos fatores que mais afeta a taxa de degradação dos agrotóxicos, pois concentrados emulsionáveis penetram rapidamente nos tecidos das plantas e apresentam curvas que evidenciam resíduos persistentes (enquanto que o pó molhável possui uma curva de degradação (dissipação) e outra de persistência (Spencer, 1965).

Dupuis (1975) afirma que a presença de resíduos em uma determinada amostra depende do tipo de produto utilizado, da estrutura e propriedades 
físico-químicas de cada produto, do tipo de pulverização, época da pulverização, número de aplicações, período de carência, formulação do produto, condições climáticas, morfologia e fisiologia da planta.

$\mathrm{Na}$ legislação brasileira são estabelecidos alguns conceitos para caracterização de LMRs e certos parâmetros toxicológicos. Assim, "resíduo de agrotóxico é uma substância ou mistura de substâncias remanescente ou existente em alimentos ou no meio ambiente decorrente do uso ou da presença de agrotóxicos e afins, inclusive quaisquer derivados específicos, tais como produtos de conversão e de degradação, metabólitos, produtos de reação e impurezas, consideradas tóxicas e ambientalmente importantes". Resíduo estranho é o "resíduo de agrotóxico e de seus produtos de transformação presentes nos alimentos mas não provenientes de sua aplicação direta. O resíduo estranho é freqüentemente devido a contaminação ambiental ou da cadeia alimentar". Dose diária aceitável ou ingestão diária aceitável (IDA) é a "quantidade máxima que, ingerida diariamente durante toda a vida, parece não oferecer risco apreciável à saúde, à luz dos conhecimentos atuais. É expressa em $\mathrm{mg}$ do agrotóxico por $\mathrm{kg}$ de peso corpóreo (mg/kg p.c.)". Limite máximo de resíduo (LMR) ou tolerância é a "quantidade máxima de resíduo de agrotóxico legalmente aceita no alimento, em decorrência da aplicação adequada numa fase específica, desde sua produção até o consumo, expressa em partes (em peso) do agrotóxico ou seus derivados por um milhão de partes de alimento (em peso) (ppm ou mg. $\mathrm{kg}^{-1}$ )". Intervalo de segurança ou período de carência é o "intervalo de tempo entre a última aplicação do agrotóxico e a colheita ou comercialização. Para os casos de tratamento de pós-colheita será o intervalo de tempo entre a última aplicação e a comercialização. Para as pastagens, será o intervalo de tempo entre a última aplicação e a reentrada dos animais no pasto". Intervalo de reentrada é o "número de dias entre a última aplicação de um agrotóxico e a reentrada de pessoas na área tratada sem risco de contaminação". A boa prática agrícola no uso de agrotóxicos é defenida como o "emprego correto e eficaz de um agrotóxico, considerados os riscos 
toxicológicos envolvidos em sua aplicação, de modo que os resíduos sejam os menores possíveis e toxicologicamente aceitáveis" ( Brasil, 1998).

\subsection{Resíduos de agrotóxicos em hortaliças}

No período compreendido entre 1982 e 1986 Luke et al. (1988) analisaram 19.851 amostras de alimentos produzidos no Estados Unidos da América ou importados; os resultados mostram que os agrotóxicos metamidofós e clorpirifós são os que tiveram maior incidência, pois foram detectados em 4.764 e 1.969 amostras, respectivamente; fenitrotion e seu análogo oxigenado não foram detectados em nenhuma amostra. No mesmo trabalho, os autores mencionam que $75 \%$ das amostras que violaram a legislação são aquelas que apresentam produtos não registrados para a respectiva cultura. Foram também analisadas 1.326 amostras de pepino para salada e conserva, sendo encontradas 320 amostras com resíduos de clorpirifós, das quais 54 foram consideradas ilegais, pois estavam com o nível de resíduo acima do LMR permitido pela legislação vigente na época.

Resíduos de fenitrotion em casca e polpa de pepino da cultivar Caipira foram avaliados por Ferst (1991). O produto comercial Sumithion 500 CE foi aplicado por ocasião da frutificação nas doses de 150 e 300 gramas de ingrediente ativo.100 litros $^{-1}$ de água, num volume de 500 litros de calda.ha ${ }^{-1}$, em duas aplicações intercaladas de 10 dias. Os frutos foram amostrados com 0 , 3 e 8 dias após a primeira pulverização e com 0, 8 e 14 dias após a segunda aplicação. Foi verificada a eficiência do processo analítico a um limite de detecção de 0,02 ppm, com uma porcentagem de recuperação de 88 a 125\%, usando cromatógrafo de gás, equipado com detector de ionização de chama alcalina (DICA). Após a primeira pulverização, foi encontrado um depósito inicial de 2,05 e $4,70 \mathrm{mg} \cdot \mathrm{kg}^{-1}$ de fenitrotion para as doses de 150 e $300 \mathrm{~g}$ i.a..100 litros $^{-1}$ de água, respectivamente, enquanto que após a segunda pulverização, o depósito inicial foi de 1,78 e 4,61 mg. $\mathrm{kg}^{-1}$ do agrotóxico, para as citadas doses. 
Esses resíduos apresentaram rápida degradação nas cascas: de 90 e 96\%, dependendo da menor e maior dose logo aos 3 dias após a primeira aplicação e não mais detectáveis aos 8 dias, enquanto que na polpa, apenas algumas amostras apresentaram níveis de resíduos até $0,04 \mathrm{mg} \cdot \mathrm{kg}^{-1}$ aos 8 dias após a primeira aplicação. A rápida diminuição dos níveis de resíduos mostrou que não é possível a distinção dos dois tipos de curvas (degradação e persistência) e sim a presença única de uma curva de degradação deste agrotóxico no fruto. Os valores de meia-vida encontrados nas cascas foram de 1 ambas as doses e nas duas aplicações. Os resíduos não foram superiores à LMR de $0,5 \mathrm{mg} \cdot \mathrm{kg}^{-1}$ no fruto como um todo, (ainda que logo após a aplicação da menor dose e aos 3 dias após a aplicação da maior dose).O autor ainda menciona que os valores semelhantes de meia-vida para as duas doses nas duas aplicações, confirmam que a velocidade de desaparecimento dos resíduos é independente dos depósitos iniciais, já relatado anteriormente por Gunther \& Blinn (1955).

Estudando a persistência e o período de carência de fenvalerato (Fenval 20 EC) nas concentrações de 0,015 e 0,03 \%, permetrina (Abush 50 EC) a 0,015 e 0,03\%, cipermetrina (Cymbush 20 EC) a 0,0075 e 0,01\% e deltametrina (Decis 25 EC) a 0,0015 e 0,002\%, em uma única aplicação no volume de 500 litros.ha na cultura de berinjela em estágio de frutificação, Awasthi (1985) verificou que os resíduos de fenvalerato persistiram por 15 dias, os de permetrina e cipermetrina por 10 dias, e os de deltametrina por 7 dias. Verificou ainda, que um período de carência, dependendo da concentração empregada, de 6 a 7 dias para fenvalerato; 3 a 5 dias para permetrina; 2 a 3 dias para cipermetrina, e zero dia para deltametrina, o qual apresentou uma degradação (dissipação) média de $72 \%$ do depósito inicial logo aos 3 dias após a aplicação, já permetiriam o consumo dos frutos.

Raha et al. (1993) fizeram uma avaliação da persistência de deltametrina (Decis 2,8\% CE) e de fenvalerato (Agrofen 20\% CE) nas folhas de frutos da planta de berinjela e também no solo, sob condições de campo, após duas pulverizações na vazão de 500 litros.ha $^{-1}$ e intercalada de 20 dias, com a 
concentração recomendada de 0,0015 e $0,015 \%$ e 0 dobro dessas concentrações para deltametrina e fenvalerato, respectivamente, quando a cultura se encontrava com $50 \%$ em frutificação. As amostras de solo e folhas foram tomadas a intervalos de $0,1,3,5,7,10$ e 15 dias após a primeira aplicação, enquanto que as de frutos foram nas mesmas datas, porém após a segunda aplicação. Os resultados revelaram que a média de depósitos iniciais dos pesticidas foi muito mais alta nas folhas do que nos frutos, e mais baixa ainda no solo, além de apresentar uma rápida dissipação dos produtos no fruto, com os resíduos já se encontrando abaixo da LMR de $2 \mathrm{mg} \cdot \mathrm{kg}^{-1}$ logo após a aplicação de fenvalerato, enquanto que para deltametrina, isto só ocorreu depois de 4 dias da aplicação da menor concentração. Segundo Raha et al. (1993), o LMR de $2 \mathrm{mg} \cdot \mathrm{kg}^{-1}$ especificado na época pela FAO/WHO, só foi alcançado aos 6,5 dias para deltametrina, quando o agrotóxico foi aplicado em dobro da concentração recomendada, enquanto que para fenvalerato, isto ocorreu também no mesmo dia da aplicação. $O$ alto depósito inicial nas folhas em relação aos frutos e solo é atribuído à disposição horizontal da lâmina foliar, natureza pubescente da sua superfície e grande superfície de área por unidade de peso delas em relação aos frutos.

Um estudo sobre a ocorrência de resíduos de clorotalonil em tomate, pepino cultivados em estufa, na Espanha, realizado por Valverde Garcia et al. (1993), obtiveram meias-vida de persitência de 11,5; 5,3 e 7,3 dias, respectivamente para essas hortaliças.

Cabras et al. (1985), estudando o comportamento de alguns resíduos de agrotóxicos na cultura de tomate em casa-de-vegetação, encontraram persistência considerável dos de deltametrina, permetrina, dicofol e pirazofós, com acúmulo dos resíduos após aplicações repetidas. Estes autores, ainda sugerem reconsideração dos parâmetros toxicológicos (LMR) e intervalos de segurança por parte das autoridades italianas.

Entre 1999 e 2000 Singh \& Gupta (2002) analisaram 162 amostras de diferentes vegetais frescos produzidos e comercializados na cidade Jaipur 
(Índia), onde o agro-clima da região é semi-árido e todos os vegetais são cultivados em sistema de irrigação, com freqüente uso de agrotóxicos. Os autores concluíram que do monitoramento de resíduos estudados no período, um total de 91 amostras estavam contaminadas com diferentes naturezas deles. Na cultura do pepino, num total de 12 amostras analisadas, apenas duas amostras estavam com os resíduos acima do LMR (clorpirifós), as quais encontravam com os resíduos na faixa de 0,9 a $1,0 \mathrm{mg} \mathrm{kg}^{-1}$ e pela legislação do país deveria ficar abaixo de $0,2 \mathrm{mg} \cdot \mathrm{kg}^{-1}$.

Oviedo et al. (2003) estudaram os resíduos de cipermetrina, deltametrina e permetrina na seguintes hortaliças: alface, acelga, chicória, repolho, tomate, chuchu, batata, cenoura, mandioca e mandioquinha. As amostras foram coletadas no restaurante da Universidade Estadual de Campinas, no período de outubro / 1998 a abril / 2001. Também foram analisadas hortaliças comercializadas na Centrais de Abastecimento de Campinas, coletadas no período de outubro / 2000 a agosto / 2001. Os resultados evidenciaram o uso inadequado desses piretróides, sendo detectados resíduos de permetrina (2,0 mg. $\left.\mathrm{kg}^{-1}\right)$ em duas amostras de alface. Em tomate, resíduos de permetrina (8,6 $\left.18,8 \mathrm{mg} \cdot \mathrm{kg}^{-1}\right)$ foram confirmados em três amostras e de cipermetrina (3,0 $\mathrm{mg} \cdot \mathrm{kg}^{-1}$ ) em uma amostra. Em relação à permetrina, os níveis encontrados em alface e tomate situaram-se acima dos LMR permitidos pela legislação vigente (0,1 $\mathrm{mg} \cdot \mathrm{kg}^{-1} \mathrm{em}$ alface e $0,3 \mathrm{mg} \cdot \mathrm{kg}^{-1} \mathrm{em}$ tomate). Quanto à cipermetrina, sua presença foi detectada em tomate, embora seu uso suja autorizado somente para as culturas de amendoim, cebola e fumo. Resíduos de deltametrina não foram encontrados nas amostras analisadas. Esses resultados indicam que as boas práticas agrícolas não estão sendo cumpridas por alguns produtores, sugerindo a necessidade de implementação de programa de monitoramento de piretróides em algumas hortaliças.

Ripley et al. (2001) estudaram resíduos de alguns inseticidas piretróides que foram aplicados em várias culturas vegetais como tratamento foliar para determinar taxas de dissipação. Em brócolis chinês (Guy Lon), mostarda 
chinesa (Pak Choi) e repolho chinês (Kasumi, napa), o fenvalerato foi persistente e apresentou resíduos de 0,10: 0,14 e 0,11 mg. $\mathrm{kg}^{-1}$, respectivamente, aos 21 dias após aplicação. Resíduos de cipermetrina em cabeça de alface estavam abaixo de 0,1 mg. $\mathrm{kg}^{-1}$ aos 10 dias após a aplicação, porém em outras duas variedades (romaine e endive) eles foram mais persistentes e dissiparam entre os dias 14 e 19 após aplicação. Após três aplicações, os resíduos de cipermetrina em cenouras colhidas e de permetrina em berinjela não foram encontrados no dia da aplicação. Em aspargos, os resíduos de deltametrina e de cipermetrina declinaram menos do que 0,1 mg. $\mathrm{kg}^{-1}$ nos dias 1 e 2, respectivamente; a permetrina foi mais persistente, necessitando de 2 dias para os resíduos declinarem para níveis inferiores a 0,1 mg. $\mathrm{kg}^{-1}$. A deltametrina não foi encontrada em cebolas (cozidas em vapor) no dia da aplicação. Em tomates, a concentração de permetrina foi de 0,093 $\mathrm{mg} \cdot \mathrm{kg}^{-1}$ no dia da aplicação e diminuiu para aproximadamente $0,05 \mathrm{mg} \cdot \mathrm{kg}^{-1}$ depois de 2-4 dias. Em geral, resíduos de permetrina, cipermetrina e deltametrina estiveram dentro dos níveis e intervalo de segurança aceitáveis. Fenvalerato comportou-se como muito persistente, especialmente nestas culturas com um LMR de 0,1 mg. $\mathrm{kg}^{-1}$.

\subsection{Resíduos de inseticidas piretróides no solo}

Chapman et al. (1981) estudaram a persistência de vários agrotóxicos (piretróides), permetrina, deltametrina, cipermetrina, fenpropatrina e esfenvalerato, em solos estéril e não estéril para avaliar a importância da biodegradação versus o mecanismo de transformação abiótica. Depois da aplicação inicial de $1 \mathrm{mg} \cdot \mathrm{kg}^{-1}$ de cada agrotóxico em solo mineral, as percentagens de recuperação após 8 semanas de incubação foram : fenpropatrina, $2 \%$; permetrina, $6 \%$; cipermetrina, $4 \%$; fenvalerato, $12 \%$; e para deltametrina, 52\%. Para solo esterilizado a recuperação foi de aproximadamente 90\%, sugerindo que a biodegradação apresenta papel 
importante no desaparecimento destes piretróides. Resultados semelhantes foram obtidos em solos orgânicos, embora a quantidade degradada, não tinha excedido a 8 semanas de período de incubação. Em solos orgânicos, a percentagem de recuperação depois de 8 semanas foram as seguintes : fenpropatrina, $8 \%$; permetrina, 16\%; cipermetrina, 16\%; fenvalerato, $58 \%$ e deltametrina, $74 \%$.

A deltametrina foi aplicada em solo franco argiloso em Alberta (Canadá), com nível inicial de fortificação de 17,5 g.ha ${ }^{-1}$ (42,5 ppb), tendo sido estudado sua degradação sob condições de laboratório e campo, por período de incubação de mais ou menos 52 semanas (Hill, 1983). A meia-vida para deltametrina sob condições de campo foi 6,8 semanas, e após 52 semanas depois de sua aplicação, restava aproximadamente $5-7 \%$ do agrotóxico. A meia-vida da deltametrina em experimentos de laboratório foi de 4,8 semanas e as diferenças na persistência entre campo e laboratório, foram atribuídas aos efeitos climáticos. Em ambos os casos, a degradação foi exponencial e o decréscimo podia razoavelmente ser enquadrado segundo uma equação de primeira ordem (Hill, 1983).

Piretrinas e piretróides foram detectados em solos agriculturáveis, em sedimentos de lagos, rios e córregos, contaminados com pulverizações terrestres ou pela contaminação da chuva superficial. Aplicações subseqüentes de agrotóxicos contendo piretrinas para múltiplos propósitos nos campos de Franklin County, Kentucky, mostraram que as concentrações de piretrinas I e II decresceram no solo em função do tempo. Depois de 1 hora; $1 ; 4 ; 8 ; 12 ; 18 ; 24$ e 30 dias, as concentrações de piretrina I era $9 ; 5,1 ; 3,9 ; 2,1 ; 0,9 ; 1,3 ; 0,3$ e 0,8 $\mu \mathrm{g} . \mathrm{kg}^{-1}$, respectivamente (Antonious et al. 1997). As concentrações de piretrina II eram 900; $140 ; 103 ; 23 ; 1 ; 1 ; 1$ e $1 \mu \mathrm{g} \mathrm{kg}^{-1}$. A concentração média de permetrina em solo coletada de 48 instalações agro-químicas no Estado de Illinois estava em $190 \mu \mathrm{g} \cdot \mathrm{kg}^{-1}$, e a faixa de concentração foi de 11 a 4,22 x 10 $\mu \mathrm{g} \cdot \mathrm{kg}^{-1}$ (Krapac et al. 1995). Entre 1996 - 1997, as concentrações de 
permetrina em amostras de solo de áreas agrícolas na Tailândia foram de 62,41 a 1,178.40 $\mu \mathrm{g} \cdot \mathrm{kg}^{-1}$ (Thapinta \& Hudak, 2000).

A permetrina foi detectada em três amostras de sedimentos num total de seis amostras e as concentrações foram de 18,1 a 21,1 $\mu \mathrm{g} \cdot \mathrm{kg}^{-1}$, aproximadamente 60 metros de um riacho onde se cultivava batata, quando ela foi aplicada em pulverização aérea (Frank et al. 1991). Após 30 dias decorridos da aplicação, o piretróide foi detectado em uma única amostra de um total de seis amostras e a concentração foi de $10 \mu \mathrm{g} \cdot \mathrm{kg}^{-1}$ (Frank et al. 1991). A deltametrina foi detectado em amostras de sedimentos em Vemmmenhog Catchment na Suíça; na média a concentração foi de $20 \mu \mathrm{g} \cdot \mathrm{kg}^{-1}$ (Kreuger et al. 1999).

Várias pesquisas extensivas sobre o destino da deltametrina em sistemas aquáticos foram realizadas por Mulla et al. (1978), Zitko et al. (1979), Bocquet \& L'Hotellier (1985) e muito outros autores. Por causa da toxicidade elevada de deltametrina aos organismos aquáticos, o conhecimento das contaminações dos córregos e de lagoas próximas às áreas tratadas são de grande interesse. Por essa razão, uma tira de filtro ou um tampão de 15 a 100 metros de largura são, normalmente usados entre áreas aplicadas quando o piretróide é pulverizado no solo ou do ar, respectivamente. Apesar destas medidas, quando acontece aplicação de deltametrina pode ser susceptível em direção e desse modo a contaminar o corpo d'água. Em conseqüência, numerosos esforços têm sido feito para caracterizar a persistência e o destino em sistemas aquáticos deste inseticida altamente tóxico no ambiente. (Maguire et al., 1989; Maguire, 1990 and 1991). O conhecimento do processo que rege o destino da deltametrina depois das aplicações, mostram que predomina na reatividade e mobilidade deste agrotóxico no ambiente. Uma importante escolha de um agrotóxico para uma cultura é seu tempo de duração para que resíduos tóxicos persistem na planta e bem como no sistema solo (ambiente).

Uma consideração importante na escolha de um inseticida durante a produção de uma cultura está no seu tempo de persistência, do resíduo tóxico 
na planta e no sistema do solo. Segundo Hill (1983) e Zhang et al. (1984), a meia-vida para deltametrina estende de uma semana até vários meses. Isto indica que esse piretróide é degradado no ambiente. A taxa de degradação é dependente de um número de fatores, tais como propriedade do solo, condições aeróbicas ou não, tempo de incubação, método de aplicação e temperatura.

Degradação e persistência da deltametrina, sob condiçãoes aeróbicas, podem ser consideradas rápidas de acordo com Kaufman \& Kayser (1979), citado pela WHO (1990). Eles acharam que a degradação da deltametrina em Dubbs, em solo argilo-arenoso e Memphis em solo franco-siltoso, ficou acima de 128 dias, que foi o período de tempo de incubação, e que à degradação e à persistência de deltametrina ocorreram rapidamente em ambos os solos, quando havia um aumento progressivo da injeção de $\mathrm{CO}_{2}$ de $62-77 \%$ e 52-60\%, respectivamente. A meia-vida da deltametrina variou de 11 a 19 dias em ambos os solos. Quando o inseticida foi aplicado em solo barro-argilo-arenoso, foi encontrada uma meia-vida de 4,9 e 6,9 semanas, em laboratório e em condições de campo (Hill, 1983). A diferença na taxa de desaparecimento foi atribuída aos efeitos climáticos. A degradação foi também estudada por Zhang et al. (1984) em um solo orgânico num período de incubação de 180 dias. Nesse estudo, a meia-vida de 72 dias foi obtida, o que indica que a deltametrina é, provavelmente mais ou menos suscetível a degradação em solo orgânico, em comparação como o solo mineral.

A perda ou desaparecimento da aplicação desse inseticida piretróide na superfície do solo tem sido reportado como, predominantemente através da decomposição da luz. Maguire (1990) argumenta que, sendo, a pressão de vapor para deltametrina é $0,002 \mathrm{MPa}$ a $25^{\circ} \mathrm{C}$, é difícil atribuir sua perda na superfície por volatilidade. Ruzo et al. (1977) documentaram sua natureza fotolabíl em solução, bem como em fase sólida, vidro ou sílica gel. Embora, importância da fotodecomposição da deltametrina na superfície do solo não seja bem compreendida, observou-se para outros piretróides sintéticos 
(permetrina, fenvalerato) que a luz solar acelera significativamente o processo de degradação. Assim, a fotodegradação pode ser responsável pela "rápida" perda na superfície. Uma vez que este processo é completado, a perda é devido ao lento processo de degradação que se torna dominante. Esta pode ser a razão para uma extensa variação da meia-vida. De acordo com Hill (1983), na ausência da luz solar, a meia-vida para deltametrina poderia ser tão longa como para diversos meses, visto que quando pulverizada na superfície do solo, sob condições de campo, sua meia-vida fica entre uma ou duas semanas.

Em razão de seu uso intensivo na agricultura a deltametrina requer uma avaliação periódica do comportamento de seus resíduos bem como destino e movimento no solo. Desse modo, a maioria das pesquisas focaliza-se em sua fotoquímica e metabolismo em plantas e animais (Cole et al., 1982; Raha et al., 1993; Westcott \& Reichle 1993; Hill et al., 1992).

\section{$2.4 \quad$ Resíduos deslocáveis}

\subsubsection{A contaminação do homem por agrotóxicos}

A contaminação do homem por agrotóxicos pode ocorrer de duas maneiras gerais: através da exposição ocupacional, no manuseio dos agrotóxicos desde a sua fabricação até a sua aplicação, e pela exposição ambiental (Bevenue, 1976).

Com relação à exposição ocupacional do homem aos agrotóxicos, a exposição dérmica é mais importante durante a operação de aplicação dos agrotóxicos (Wolfe et al., 1972).

A exposição dérmica representa a quase totalidade da exposição ocupacional; portanto a pele do trabalhador deve ser bem protegida. As medidas de controle da exposição dérmica basicamente são através de equipamentos de proteção individual (EPIs) e por redução da condição insegura que a atividade representa (Machada Neto, 1991) 
O monitoramento ocupacional tem se mostrado a forma mais eficiente de prevenir e diagnosticar precocemente os episódios de intoxicações provocados por pesticidas, em particular os provocados por agrotóxicos anticolinesterásicos. A utilização dos agrotóxicos no meio rural brasileiro tem trazido uma série de conseqüências tanto para o ambiente como para a saúde do trabalhador rural. Em geral, essas conseqüências são condicionadas por fatores intrinsecamente relacionados, tais como o uso inadequado dessas substâncias, a alta toxicidade de certos produtos, a falta de utilização de equipamentos de proteção e a precariedade dos mecanismos de vigilância. Esse quadro é agravado pelo baixo nível socioeconômico e cultural da grande maioria desses trabalhadores (Oliveira-Silva et al., 2001)

As intoxicações agudas de aplicadores de agrotóxicos no Brasil são elevadas e, segundo Rüegg et al. (1991), nessa época havia ocorrência de um caso de intoxicação aguda em cada 8 trabalhadores agrícolas examinados. Estima-se, ainda, que cerca de $2 \%$ da população brasileira é contaminada anualmente por agrotóxicos e que, para cada caso constatado em hospitais e ambulatórios, deve haver, aproximadamente, 250 vítimas não registradas, principalmente pela falta de conhecimentos toxicológicos dos médicos (Machado Neto, 1990).

Na reentrada, a exposição se dá durante atividades de intenso contato com a cultura como colheita de frutos, hortaliças e flores (Hemmen, 1993)

A exposição dérmica pode ser real ou potencial; está é considerada como a quantidade do agrotóxico coletada sobre a pele exposta, sobre as roupas, luvas protetoras, etc, e considerada como teoricamente capaz de alcançar a pele na ausência de vestimentas ou completa penetração através delas (Turnbull et al., 1985)

A exposição dérmica real, segundo Bonsall (1985), é a quantidade absoluta de um agrotóxico qualquer, que entra em contato com a pele (sem a proteção da roupa), e portanto, disponível para absorção. 
Delgado \& Paumgartten (2004) realizaram um trabalho que é parte de um estudo mais amplo sobre as conseqüências para a saúde da exposição aos agrotóxicos. Em 1997, no Município de Paty do Alferes, Rio de Janeiro, 55 agricultores foram entrevistados sobre o uso de agrotóxicos, equipamentos de proteção e medidas de higiene, ocorrência de intoxicações, destino das embalagens vazias e o tipo de orientação técnica recebida pelos usuários destes produtos. Os agrotóxicos mais usados eram a abamectina, os compostos oraganofosforados e os piretróides, e os fungicidas como o mancozeb, o clorotalonil e produtos à base de cobre. Entre os trabalhadores envolvidos no preparo e/ou aplicação de agrotóxicos, 92\% informaram não usar qualquer tipo de equipamento de proteção individual, 62\%dos agricultores entrevistados informaram já ter "passado mal" ao preparar ou aplicar agrotóxicos. Os sintomas mais freqüentes citados foram dor de cabeça, enjôo, vômitos, vertigem, irritação da pele e visão embaçada. Destes agricultores, 21\% necessitaram de assistência médica e em mais da metade dos casos (51\%), em que os lavradores identificaram os agrotóxicos que usaram quando "passaram mal" foram citados os organosfosforados da classe toxicológica I.

Machado Neto (1990) avaliou a exposição de aplicadores de agrotóxicos em cultura de tomate, e a eficiência de equipamentos de proteção individual e coletiva. O autor constatou, a distribuição da exposição dérmica esta concentrada nos membros inferiores. Essa exposição pode ser reduzida com utilização de equipamentos de proteção individual e coletiva. O risco de intoxicação estimado em termos da percentagem de dose tóxica por hora, com o inseticida metamidofós foi de $12 \%$ ao ser aplicado com equipamento convencional para a cultura.

\subsubsection{Resíduos deslocáveis em algumas culturas}

Segundo Gunther et al. (1973), no estudo de resíduo deslocável é importante o estabelecimento de técnicas específicas, que possam ser 
seguidas em trabalhos com diversas culturas tratadas com o agrotóxico, nas quais são freqüentes o contato dos trabalhadores com a folhagem, como morango, fumo, algodão, alface, tomate, videira e maioria das frutíferas arbóreas

O resíduo deslocável é uma porção de um resíduo de agrotóxico numa vegetação tratada que é prontamente removida e pode constituir-se em risco para os trabalhadores rurais. É geralmente determinado pelo resíduo removido quando discos foliares de plantas são agitadas por curto período em água (International Union of Pure and Applied Chemistry, 2004)

Em um estudo sobre resíduos de paration na superfície de folhas, frutos e solo, e no ar em cultura de laranja "Valencia" na Flórida. Nigg et al. (1979) observaram que o maior potencial de exposição ao paration foi representado por folhas e solo, sendo que para o paraoxon a superfície foliar foi mais representativa. Os autores sugerem que superfícies de folhas e solo podem ser suficientes para avaliar níveis de resíduos de agrotóxico para proteção de trabalhadores, em condições de reentrada na cultura de laranja.

Segundo Nigg et al. (1984a), as partículas aderidas na folha tem sido críticas para o transporte do agrotóxico da superfície foliar para o trabalhador, e destacam que diferenças no ambiente podem diferir regionalmente a exposição do trabalhador no campo.

Foi realizado um estudo sobre a dissipação dos resíduos deslocáveis de carbosulfan em pomares de laranja. Nigg et al. (1984b) observaram que a dissipação ocorreu rapidamente, tanto na folha e fruto, sendo significativo no outono, em relação ao inverno.

Resíduos deslocáveis de carbofenotion e seu análogo oxigenado foram estudados por Batista et al.(1985), em folhas e solo de cultura de laranja na Flórida. Foram observados baixos níveis do análogo oxigenado, bem como uma degradação uniforme. A dissipação de carbofenotion nas folhas e solo teve comportamento semelhante. 
Winterlin et al. (1984) estudaram o comportamento dos resíduos deslocáveis dos fungicidas captan e seu metabólito tetrahidroftalimida (THPI) em folhas e frutos de morango durante 14 dias, e observaram que eles se mostraram bastante estáveis nos frutos, mas que parte deles poderiam ser originados das folhas. Os resíduos de THPI também decresceram lentamente e, na folhagem, eram cerca de $1 \%$ da quantidade real aplicada.

Giles \& Blewet (1991), baseados em uma série de trabalhos anteriores, citam que a exposição dérmica é fortemente correlacionada com níveis de resíduos foliares deslocáveis, e que esta relação leva ao desenvolvimento de um fator de transferência empírico desenvolvido por Popendorf \& Leffingwell (1982). A validade prática do fator de transferência, é que ele permite uma estimativa da exposição baseada no nível de resíduo foliar deslocável. Os autores sugeriram que técnicas de aplicação com volumes reduzidos diminuem em $50 \%$ o volume do fungicida captan, e mesmo em aplicações contínuas a cada 14 dias, não aumentam os resíduos deslocáveis. Entretanto, se não houver redução na dose de ingrediente ativo, o uso da técnica pode elevar a exposição dérmica potencial do trabalhador em $70 \%$.

Zweig et al. (1983) estudaram a relação existente entre dois agrotóxico com resíduo deslocável (folha) na cultura de morango e a exposição dérmica, e constataram que a taxa média de resíduos deslocáveis (folha) dos fungicidas captan e benomil são similares à taxa média de exposição dérmica. Isto sugere que os resíduos deslocáveis (folha) são transferidos na mesma proporção para a superfície da pele do trabalhador.

Os resíduos deslocáveis também podem estar presentes na superfície do solo. Os agrotóxicos que atingem a superfície do solo, devido ao excesso de depósito na planta, foram relatados por Spencer et al. (1975) como fonte de substâncias tóxicas para o trabalhador em campos tratados com agrotóxicos. Os autores relatam que o inseticida paration no solo, provindo de pulverização na cultura ou pulverizado diretamente no solo por ocasião da aplicação, pode 
persistir por longo período e ser ativado ao seu análogo paraoxon (metabólito altamente tóxico ao ser humano).

A importância dos resíduos de agrotóxicos no solo está de no fato da poeira ser mobilizada e carregada para a superfície da folhagem, com as quais o trabalhador entra em contato, e também por contato direto com o solo, através dos pés, o que de fato é uma realidade nos países em desenvolvimento (Spencer et al., 1977).

Gunther et al. (1977) e Nigg (1979) citam que partículas de agrotóxicos, transportadas para a superfície das folhas resultam em exposição dérmica, e que alta percentagem de partículas menores que 50 micras dessas substâncias presentes no solo são facilmente transferidas para o trabalhador.

\subsubsection{Fatores que determinam exposição aos agrotóxicos}

Segundo Popendorf \& Leffingwell (1982), a aplicação de um agrotóxico numa cultura resulta em um depósito inicial, que se transforma em resíduo de grandeza reduzida e forma alterada. A entrada do trabalhador para colheita e outras atividades na área tratada, coloca-o em contato com o produto depositado sobre a superfície de folhas e frutos, de modo a ocorrer a transferência desses resíduos para a pele do trabalhador. O decréscimo desses resíduos é uma função do tempo e de outros importantes fatores adicionais como a natureza do agrotóxico, cultura e condições climáticas.

Como fatores que afetam a exposição têm-se o tipo de cultura, a taxa de trabalho do colhedor (está relacionado com a quantidade de contato com a planta), método de trabalho, dose aplicada e condições climáticas (Nigg \& Stamper, 1989 e Hemmen, 1993).

De acordo com Brouwer et al. (1990), a exposição dérmica durante a colheita de cravos depende da quantidade de agrotóxico presente na parte externa das folhas, denominada resíduo deslocável (foliar), e que mais de $65 \%$ da variação da exposição dérmica pode ser atribuída a esses resíduos. Esses 
autores relatam que não há influência do tipo de agrotóxico e método de aplicação.

Segundo Hemmen (1993), a exposição é menos dependente da natureza química do agrotóxico. Deste modo, a exposição à um agrotóxico, pode ser extrapolada para outros, baseado no conhecimento de vários fatores como equipamento, condições climáticas, método de trabalho e dose aplicada, os quais determinam a exposição.

Hayes (1975) relata que a exposição dérmica a um composto pode ser afetada pelo tipo de formulação, concentração do ingrediente ativo nela, método e duração da aplicação e conduta do trabalhador no campo.

Uma variável importante que afeta a exposição é a taxa de trabalho. Conforme relata Zweig et al. (1983), o trabalhador que colhe grande quantidade de frutos, tem maior contato com a folhagem, e conseqüentemente com resíduos deslocáveis dos agrotóxicos.

Um grupo de colhedores de morangos foram monitorados por Zweig et al. (1985) para avaliação da exposição dérmica a carbaril e níveis de resíduo foliar deslocável. De acordo com os autores, o principal local de exposição dérmica são as mãos e os braços. McCatthy (1982) cita que fatores climáticos afetam a exposição como temperatura, luminosidade, umidade e condições atmosféricas, além da formulação do agrotóxico, dosagem e o tipo de cultura. Popendorf (1985) relata que mecanismo como vento, deposição foliar, dosagem, evaporação e absorção foliar, podem reduzir o resíduo inicial.

Evaristo (1994) estudou o comportamento de resíduos deslocáveis de metamidofós em folhas, frutos e solo em cultura estaqueada de tomate. $\mathrm{O}$ experimento constou de quatro tratamentos (com quatro repetições): (1) uma aplicação de metamidofós (Tamaron BR) em dosagem simples de 60 g. i. a.100 litros $^{-1}$ de água, (2) uma aplicação em dosagem dobrada de 120 g. i. a.100 litros $^{-1}$ de água, (3) quatro aplicações na dosagem simples, (4) testemunha. Segundo a autora, as amostras de folhas, frutos e solo foram colhidas um dia antes da aplicação conjunta, e depois ao 0, 1, 2, 3, 5, 7 e 14 dias após. Os 
resíduos deslocáveis nas folhas nos tratamentos com quatro aplicações na dosagem simples e uma aplicação com o dobro da dosagem tiveram degradações semelhantes com meias-vida de 0,7 e 0,9 dia, respectivamente. No tratamento com uma aplicação na dosagem simples, a meia-vida foi de 2,4 dias. O comportamento dos resíduos deslocáveis no solo nos tratamentos de metamidofós na dosagem simples ( uma e quatro aplicações) foi semelhante, com meias-vida de 2,9 e 2,7 dias, respectivamente. A meia-vida no tratamento com a dosagem dupla foi de 1,3 dia. Isto evidencia que os resíduos no solo são mais persistentes do que aqueles das folhas. Os níveis de resíduos deslocáveis nos frutos foram detectados apenas na amostras de 0 e 1 dia, e eles decresceram de 0,19 a 0,05 $\mu \mathrm{g} \cdot \mathrm{cm}^{-2} ; 0,27$ a 0,06 $\mu \mathrm{g} \cdot \mathrm{cm}^{-2}$ e 0,11 a 0,05 $\mu \mathrm{g} \cdot \mathrm{cm}^{-2}$; respectivamente nos tratamentos com uma aplicação na dosagem simples, uma na dupla e quatro na simples. Esses resultados mostram que a degradação dos resíduos deslocáveis é relativamente muito rápida.

\subsection{Deltametrina}

A deltametrina é um inseticida do grupo químico dos piretróides, conhecido quimicamente pelo nome químico (IUPAC): (S)-alpha-ciano-3-phenoxybenzyl (1R,3R)-3-(2,2-dibromovinyl)-2,2-dimethylcyclopropanecarboxylate; sua fórmula estrutural é mostrada na Figura 2 e suas propriedades físicas e químicas na Tabela 1 (Tomlin, 1995).

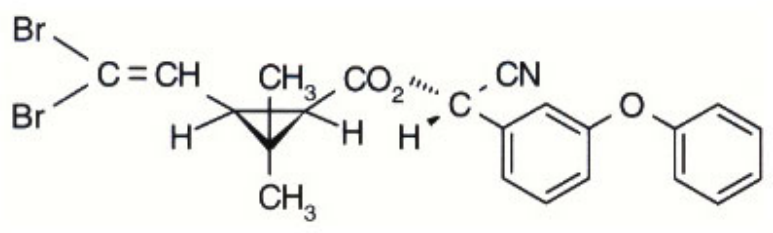

Figura 2 - Fórmula estrutural da deltametrina 
Tabela 1. Propriedades físicas e químicas da deltametrina

\begin{tabular}{lc}
\hline \multicolumn{1}{c}{ Parâmetros } & Valores \\
\hline Fórmula química & $\mathrm{C}_{22} \mathrm{H}_{19} \mathrm{Br}_{2} \mathrm{NO}_{3}$ \\
peso molecular & 505,2 \\
ponto de fusão & $100-102^{\circ} \mathrm{C}$ \\
coeficiente de partição (kow) & $4,6\left(25^{\circ} \mathrm{C}\right)$ \\
solubilidade em água & $<0,2 \mu \mathrm{g} / \mathrm{L}$ \\
pressão de vapor $\left(25^{\circ} \mathrm{C}\right)$ & $1,33 \times 10^{-5} \mathrm{~Pa}$ \\
\hline
\end{tabular}

Fonte: Tomlin (1995)

Possui $\mathrm{DL}_{50}$ aguda oral de $135 \mathrm{mg} \cdot \mathrm{kg}^{-1}$ para rato albino, para cães é > $300 \mathrm{mg} \cdot \mathrm{kg}^{-1} ; \mathrm{DL}_{50}$ aguda dérmica $>2000 \mathrm{mg} \cdot \mathrm{kg}^{-1}$ para ratos (Tomlin, 1995). No Brasil, é comercializado com vários nomes entre os quais: Decis $25 \mathrm{CE}$, Decis $100 \mathrm{CE}$, Decis 200 SC e Decis 50, estando registrado segundo algumas formulações para uso em mais de 30 culturas, entre as quais a de pepino, nesta; com LMR de 0,01 de mg. $\mathrm{kg}^{-1}$ ( $\mathrm{ppm}$ ) e intervalo de segurança de 2 dias (Agencia Nacional de Vigilância Sanitária, 2004)

Balwinder et al. (1989) estudaram resíduos dos inseticidas piretróides cipermetrina, fenvalerato e deltametrina em tomate, utilizando a dose recomendada e o dobro da dosegem (50 e $100 \mathrm{~g}$. i. a. / ha para cipermetrina e fenvalerato, e 12 e $24 \mathrm{~g}$ de i. a. ha ${ }^{-1}$ para deltametrina) em condições subtropicais. As pulverizações começaram quando cerca de $50 \%$ das plantas encontrava-se em pleno florescimento e continuaram a intervalos de 10 dias uma da outra num total de 4 pulverizações. As amostras de tamanho comercial foram analisadas zero, 1, 2, 4, 6, 8 e 10 dias após a última aplicação. Imediatamente após a quarta pulverização, o resíduo médio de cipermetrina estava entre 0,25 e 0,48 mg. $\mathrm{kg}^{-1}$ para a menor e maior dosagem, respectivamente. Estes foram reduzidos para 0,13 e 0,22 mg. $\mathrm{kg}^{-1}$, em 1 dia e para 0,07 e $0,08 \mathrm{mg} \cdot \mathrm{kg}^{-1}$, respectivamente em 4 dias. Não foram detectados 
resíduos com 6 e 8 dias após a última aplicação na menor e maior dosagem, respectivamente. Com o LMR para cipermetrina estabelecido em $0,5 \mathrm{mg} \cdot \mathrm{kg}^{-1}$, até mesmo nos levantamentos iniciais os resíduos estavam abaixo dele. Para ambos os tratamentos de fenvalerato os depósitos iniciais foram de 0,29 e 0,49 mg.kg menores que o LMR de $1 \mathrm{mg} \cdot \mathrm{kg}^{-1}$. Para deltametrina o depósito máximo inicial foi de 0,09 e $0,23 \mathrm{mg} \cdot \mathrm{kg}^{-1}$, considerados pelos autores como muito baixo.

Saldivar (1998) investigou a extensão do uso químico empregado na produção e determinou os níveis de resíduo em legumes, frutas e grãos nas principais áreas produtoras das Filipinas, no período de janeiro / 1994 a junho / 1996. Resíduos de alguns inseticidas, dentre estes os de deltametrina, foram encontrados em agumas amostras de tomate, maçã ampalaya (Filipinas), berinjela, pimentão e feijões de Baguio com valores tão altos que ultrapassariam a ingestão diária aceitável (IDA) nas dietas, considerando-se a composição destas. Das amostras vegetais totais analisadas pelo NCPC, UPLB (National Crop Protection Center, Philippines Univ. Los Banos, College, Laguna), 51,1\% continham resíduos de agrotóxicos e $26,82 \%$ excediam os LMRs, enquanto que 24,39\% estavam abaixo dele. Para arroz, resíduos de deltametrina e de outros piretróides também foram encontrados. Das amostras analisadas, $56,25 \%$ continha resíduos químicos e $47,16 \%$ excediam os respectivos LMRs.

Prem et al. (1999) estudaram a magnitude dos resíduos de acefato, malation, endosulfan e deltametrina em frutos de tomate (cv. Roma), quando aplicados nas concentrações recomendadas, em experimentos no campo durante o verão de 1998 / 1999 em Lullu, Himachal Pradesh (Índia). Os dados de resíduos foram agrupados para calcular parâmetros de segurança como $\mathrm{RL}_{50}$. O depósito inicial de malation era mais alto que o de todos os outros inseticidas. Os resíduos, entretanto, apresentaram um valor de meia-vida $\left(R L_{50}\right)$ de 1,6 dias para esse inseticida, 1,8 dias para acefto, 1,6 dias para endosulfan e 1,4 dias para deltametrina. Os resíduos de acefato estavam abaixo do LMR de 3,9 dias, enquanto os de endosulfan 3,3 dias; e assim, um quarto dia de 
período de espera foi sugerido para ambos os inseticidas. Por outro lado, os depósitos iniciais de malation e deltametrina estavam abaixo do LMR e, conseqüentemente, nenhum período de espera foi adicionalmente sugerido.

\subsection{Descrição, importância e controle da broca-das-cucurbitáceas}

A broca das cucurbitáceas (Diaphania nitidalis) está entre as principais pragas do pepineiro. Os maiores danos ocorrem na fase reprodutiva da cultura, quando suas larvas penetram nos frutos, alimentando-se da polpa e tornandoos impróprios para o consumo (Cantliffe \& Phatak, 1975).

Tradicionalmente, o controle de $D$. nitidalis é feito através de aplicações de inseticidas sintéticos. Contudo, o uso contínuo desses produtos torna-se indesejável por vários motivos, dentre os quais se destaca o aparecimento de novas espécies-pragas ou a ressurgência de outras, toxicidade ao homem e inimigos naturais, além do seu elevado custo. Desta forma, o estudo dos aspectos de manejo integrado de pragas (MIP) torna-se cada vez mais importante.

D. nitidalis é uma mariposa de $30 \mathrm{~mm}$ de envergadura e $15 \mathrm{~mm}$ de comprimento. Tem coloração marrom-violácea, com as asas apresentando uma área central amarelada semitransparente, e os bordos marrom-violáceos. A fêmea efetua a postura nas folhas, ramos, flores ou frutos, e suas lagartas, que são esverdeadas, atingem $20 \mathrm{~mm}$ de comprimento. Essas lagartas alimentamse de qualquer parte vegetal, mas dão preferência aos frutos, razão pela qual são chamadas de brocas-das-cucurbitáceas. Após o período larval, que é de aproximadamente 10 dias, transformam-se em pupas sobre folhas secas ou no chão e passam ao estágio adulto após mais 12 a 14 dias. Assim, o cilco evolutivo completo é de cerca de 25 a 30 dias. Essa praga ocorre com maior intensidade de setembro a março, diminuindo em outros períodos do ano (Gallo et al., 2002). 
São pragas às vezes limitantes para a cultura. Atacam as folhas, brotos novos, ramos e, principalmente, os frutos. Os brotos novos atacados secam-se e os ramos ficam com as folhas secas. Nos frutos abrem galerias e destroem a polpa, acarretando seu apodrecimento e inutilização.

Barbosa (1984) cita que o controle de pragas com piretróides sintéticos apresentam ótimos resultados contra algumas pragas de hortaliças como lagarta rosca, vaquinhas, traças e mosca-das-frutas, mas não apresentam bom controle de insetos sugadores e minadores de folhas, sendo necessário o uso de alguns agrotóxicos (organofosforados ou carbamatos).

França et al. (1985) estudaram o controle da broca-das-cucurbitáceas $D$. nitidalis (Cramer, 1782) (Lepdoptera, Crambidae) e Diaphania hyalinata (L., 1758) em pepino com avermectina 1,8 CE, Arrivo $20 \mathrm{CE}$, Sumition $50 \mathrm{CE}$, Thiobel 50 PS, Sumicidin 20 CE, Dipterex 50 CE, Naled-8E 86 CE, Pounce 38,4 CE, Orthene 75 OS, Thodan 35 CE, Malatol 50 CE, Dipel PM, Sevin 85 PM, FMC 65318 5.6 CE, Baythroid 5 CE, Decis 2,5 CE, HOE 52215 CE, não sendo encontradas diferenças significativas entre os produtos testados.

Sassaki \& Kimoto (1986) testaram os inseticidas piretróides esfenvalerato

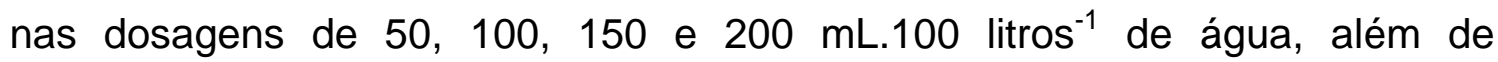
deltametrina na dosagem de $30 \mathrm{~mL} .100$ litros $^{-1}$ de água e fenvalerato com 75 $\mathrm{mL} .100$ litros $^{-1}$ de água,para controle da broca dos frutos, Diaphania spp., do pulgão Aphis gossypii Glover, 1877 (Hemíptera:Aphididae) e do ácaro Tetranychus spp. (Acari:Tetranychidae) na cultura do pepino; os resultados não apresentaram diferenças significativas entre si, todos mostrando um bom controle.

Para o controle de D. nitidalis, na cultura do pepino, Lorini \& Foerster (1987) testaram os seguintes inseticidas e respectivas dosagens em gramas de ingrediente ativo / 100 litros de água: permetrina 10 (Ambush $50 \mathrm{CE}$ ); permetrina 10 (Pounce $384 \mathrm{CE}$ ); acefato 56,25 (Orthene 75 OS); cartap 75 (Thiobel $50 \mathrm{OS}$ ); etion 50 (Ethion $50 \mathrm{CE}$ ); detametrina 1,0 (Decis 2,5 CE); metomil 43 (Lannate); clorpirofós 48(Lorsban 480 BR) e aldicarb (Temik $10 \mathrm{G}$ ) 
$1000 \mathrm{~g}$ i.a.ha ${ }^{-1}$, aplicado no solo. Os inseticidas acefato, clorpirifós e metomil foram os que apresentaram os melhores resultados para o controle da broca; citam ainda que a broca é a principal praga da cultura do pepino na atualidade, pois ataca diretamente os frutos.

Scarpellini (1989) afirma que os cultivos de pepino no outono sofrem redução de $44 \%$ na produção, quando a desfolha atinge $25 \%$ aos 45 dias após a germinação e, aos 15 dias após a germinação; mesmo com desfolhamento inferior à 25\%, a redução na produção é de 51\%.

Villas Bôas (1989) comenta que o controle das pragas através de produtos químicos é atualmente o método de controle mais usado em hortaliças, sendo muito difícil o cultivo destas na forma intensiva, sem o uso destas substâncias, ainda que tenham sido desenvolvidos grandes esforços na última década buscando-se métodos alternativos.

Os frutos de pepino, apresentam um rápido desenvolvimento, como mostra Demattê (1978) que estudou várias cultivares de pepino e, em média geral, observou que em apenas 3 dias, os frutos podem dobrar de peso, dependendo da época do ano, condições climáticas, nutrição das plantas e seu estágio de desenvolvimento. 


\section{MATERIAL E MÉTODOS}

\subsection{Experimento}

O Experimento foi conduzido em condições de campo, no Município de Piedade-SP (coordenadas geográficas: latitude $23^{\circ} 42^{\prime} 43^{\prime \prime}$ S; longitude $47^{\circ} 25^{\prime}$ $40 "$ W). A semeadura foi realizada no dia 08/novembro/2003, em covas com espaçamento de 1,0 entrelinhas $\times$ 0,5 metros entre plantas. Foi utilizado a cultivar de pepino do tipo "Caipira", híbrido "Safira" e conduzido em sistema tutorado, sujeito apenas à regime normal de chuvas.

$\mathrm{O}$ solo onde vegetaram as plantas de pepino foi um Gleissolo com as seguintes características: matéria orgânica $=67 \mathrm{~g} \cdot \mathrm{dm}^{-3} ; \mathrm{pH}\left(\mathrm{CaCl}_{2}\right)=4,2 ; \mathrm{CTC}=$ 120,3 mmolc. $\mathrm{dm}^{-3}$; argila $=51,5 \%$; areia grossa $=21,5 \%$; areia fina $=11,1 \% \mathrm{e}$ silte $15,9 \%$.

O delineamento experimental foi de blocos ao acaso com 4 tratamentos e 3 repetições. $O$ isolamento entre blocos deu-se por bordaduras constituídas de duas linhas duplas de plantas, sendo as parcelas separadas dentro do bloco por 10 plantas em linhas duplas. A unidade experimental (parcela) foi constituída de 07 metros de linhas duplas espaçadas 0,50 metros entre si e, igualmente, 0,50 metros entre plantas.

Foram realizadas adubações na cova de plantio com $100 \mathrm{~g}$ da fórmula 416-8 de NPK e duas aplicações em cobertura com sulfato de amônio (10g/planta) no raleamento e no início da formação dos frutos.

Não houve ataque de pragas durante a fase vegetativa, mas na fase reprodutiva houve ataque de broca-das-cucumbitáceas, ataque este que foi registrado durante as amostragens. 
O inseticida utilizado foi deltametrina, aplicado em três formulações diferentes, a saber : o Decis 25 CE; o Decis Ultra 100 CE e o Decis 200 SC, (todos na dose de 0,75 gramas do ingrediente ativo.100 $\mathrm{L}^{-1}$ de água); 


\subsection{Tratamentos}

Os tratamentos aplicados foram os seguintes:

1 - testemunha;

2 - três (3) aplicações na dosagem de $30 \mathrm{~mL}$ de Decis 25 CE.100 $\mathrm{L}^{-1}$ de água;

3 - três (3) aplicações na dosagem de 7,5 mL de Decis Ultra 100 CE.100 L $\mathrm{L}^{-1}$ de água;

4 - três (3) aplicações na dosagem de 3,75 mL de Decis 200 SC.100 $\mathrm{L}^{-1}$ de água.

As aplicações foram realizadas em dia 24 e 31 de dezembro de 2003 e 08 de janeiro de 2004, com auxílio de um pulverizador costal mantido à pressão constante de $60 \mathrm{PSI}$ com $\mathrm{CO}_{2}$, volume de calda de $800 \mathrm{~L}$. ha ${ }^{-1}$, equipado com bico cônico vazio D2-23, como recomendado, e suficiente para saturação da parte aérea (início de escorrimento).

\subsection{Amostragens}

As amostras de frutos e solo foram colhidas com (-1), zero, 1, 3, 5 e 7 dias após a última aplicação, sendo a primeira amostragem em 07/janeiro e a última em 15/janeiro/2004.

As amostragens de folhas e resíduos deslocáveis foram tomadas com (-1), zero, 1, 3, 5, 7 e 14 dias após a última aplicação, sendo a primeira amostragem em 07/janeiro e a última em 22/janeiro/2004. 
As amostras de frutos foram constituídas de 12 unidades cada uma, tomadas ao acaso.

Para as folhas, as amostras constituíram em 40 unidades cada uma, tomadas ao acaso de cada parcela, buscando-se respeitar sua distribuição espacial nas plantas, de modo a torná-las tão representativas quanto possível.

As amostragens de solo seguiram a mesma programação das de frutos; para tanto, foram tomadas 4 sub-amostras por parcela, da profundidade de 0-10 $\mathrm{cm}$, com auxílio de um trado, que constituíram uma única amostra composta (aproximadamente $180 \mathrm{~cm}^{3}$ ). Para evitar que os mesmos pontos fossem posteriormente amostrados, um palito de sorvete foi fixado em cada um dos pontos anteriormente amostrados. As amostras foram acondicionadas em embalagens plásticas.

Para as análises de resíduos deslocáveis, as amostras, de cada parcela, foram constituídas de 40 discos de $2,5 \mathrm{~cm}$ de diâmetro cada um, que foram amostradas ao longo de duas linhas duplas, em ambos os lados da mesma, e nas partes inferior, média e superior das plantas. Para coleta dos discos foliares foi utilizado um vazador mecânico equipado com um recipiente (tubo de filme fotográfico), abaixo colocado, para recolher os discos. As amostras foram processadas no mesmo dia, seguindo sugestão Iwata et al. (1977) e Gunther et al. (1973).

O total de amostras analisadas foi de 312 , assim destribuídas: fruto 72 , folhas 84 , solo 72 e resíduos deslocáveis 84 .

Para correlação entre os resíduos de deltametrina, nos diferentes compartimentos da cultura, foram tomados dados climáticos diários de temperatura máxima, mínima e de precipitação atmosférica, relativos ao período de duração do experimento e obtidos na Diretoria Municipal de Agricultura, Abastecimento e Meio Ambiente, Piedade-SP, apresentados no Apêndice I. 


\subsection{Limites de quantificação, porcentagens de recuperação e descrição do método de análises de resíduos de deltametrina em amostras de fruto, folha, solo e resíduos deslocáveis}

Para os estudos dos limites de quantificação e porcentagens de recuperação de deltametrina foram fortificadas amostras de fruto, de modo a se obter concentrações nos níveis: 0,02 e 0,2 $\mathrm{mg} \mathrm{kg}^{-1}$ (ppm); de folhas: 0,05 e 0,5 mg. $\mathrm{kg}^{-1}$ (ppm), de solo: 0,01 e 0,1 mg. $\mathrm{kg}^{-1}$ (ppm) e amostras de resíduos deslocáveis em folha: 0,2 e 2,0 ng. $\mathrm{cm}^{-2}$. Nos estudos, todos os níveis de fortificação, para os diversos substratos, foram feitos em triplicata. Foram fortificadas 24 amostras, a saber: 2 níveis $\times 4$ substratos $\times 3$ repetições.

\subsection{Método para análise de resíduo de deltametrina em fruto, folha, solo e resíduos deslocáveis}

\subsubsection{Fruto e folha}

O método de análises foi adaptado de Andersson \& Palsheden (1998), que consta da extração dos resíduos do inseticida com acetato de etila em presença de $\mathrm{Na}_{2} \mathrm{SO}_{4}$. Uma alíquota do extrato é concentrada por evaporação e os resíduos ressuspendidos em uma mistura de acetato de etila / ciclohexano; a seguir procede-se a limpeza por técnica de cromatografia de permeação em gel (GPC), sendo a eluição procedida com a citada mistura. Após nova concentração, o extrato é ressuspendido na mesma mistura de ciclohexano / acetato de etila; segue-se determinação quantitativa, realizada por técnica de cromatografia em fase gasosa, usando-se cromatógrafo HP, modelo 6890, equipado com detector de captura de elétrons $\left(\mu-\mathrm{ECD}, \mathrm{Ni}^{63}\right)$. 


\section{A. Aparelhos/Equipamentos}

- $\quad$ agitador/homogeneizador, Minishaker, modelo MS-1;

- balança analítica, Mettler, modelo H10;

- $\quad$ balança analítica, Sartorius, modelo Basic;

- $\quad$ bomba binária, Gilson, modelo 321;

- $\quad$ centrífuga, Revan, modelo Ciclo C-I;

- coluna cromatográfica, megabore, HP-608, 30 m comprimento, diâmetro $0,53 \mathrm{~mm}$ e $0,5 \mu \mathrm{m}$ espessura do filme;

- colunas (duas, ligadas em série) PLGel, para cromatografia de permeação em gel, 300 × 7,5 mm $\phi$;

- cromatógrafo de gás, HP, modelo 6890, equipado com detector de captura de elétrons $\left(\mu-\mathrm{ECD}, \mathrm{Ni}^{63}\right)$;

- $\quad$ evaporador TurboVap, Zymark, modelo LV;

- $\quad$ evaporador TurboVap, Zymark, modelo II

- injetor/coletor de frações, Gilson, modelo 215 para cromatografia de permeação em gel (GPC);

- $\quad$ mesa agitadora Marconi, modelo FVR-C9S

- $\quad$ multiprocessador Sire Cutter;

- $\quad$ triturador Ultra-turrax, Heidolph, modelo DIA.900;

- $\quad$ ultra-som, Mini-som;

- $\quad$ software ChemStation, Ver. A.06.03 (509);

- $\quad$ workstation HP, modelo Kayak XA.

\section{B. Solventes/Reagentes}

- acetato de etila, nanograde, Mallinckrodt;

- ciclohexano, PA-ACS, destilado em destilador de vidro;

- $\mathrm{Na}_{2} \mathrm{SO}_{4}$, anidro granulado, QM; 
- padrão analítico de deltametrina.

- padrão analítico de bifentrina (padrão interno)

- sílica gel, dessecante azul

- sílica gel $60 \mathrm{GF}_{254}(90 \%<45 \mu \mathrm{m})-$ Merck.

\section{Vidrarias e outros materiais}

- $\quad$ beakers, 10, 20, 50 e $100 \mathrm{~mL}$, Corning/Pyrex 1000;

- $\quad$ filtro de sílica-gel;

- $\quad$ filtros de membrana, Millipore 0,20 $\mu$ (Millex FG);

- frascos de vidro com tampa rosqueável de 100 e $250 \mathrm{~mL}$, Duran-Schott;

- $\quad$ funil de separação $250 \mathrm{~mL}$;

- $\quad$ funil de vidro;

- $\quad$ luvas de nitrila

- $\quad$ micro-seringa, $10 \mu \mathrm{l}$, Hamilton;

- $\quad$ pipetador automático, Handy Step - Brand;

- $\quad$ pipetas de Pasteur;

- $\quad$ pipetas volumétricas e graduadas, $1,2,3,4,5$, e $10 \mathrm{~mL}$;

- $\quad$ provetas graduadas, 10, 25, 50 e $100 \mathrm{~mL}$;

- $\quad$ seringas hipodérmicas, $\mathrm{BD}$, plástico, 5 e $10 \mathrm{~mL}$;

- $\quad$ suportes para tubos de centrífuga;

- $\quad$ tubos de centrífuga, polipropileno, $15 \mathrm{~mL}$, Corning 25330-15;

- $\quad$ tubos de ensaio de 12 e $15 \mathrm{~mL}$.

- vials de vidro, $1,5 \mathrm{~mL}$, próprios para uso no injetor automático do cromatógrafo;

- $\quad$ vials de vidro, $4 \mathrm{~mL}$, próprios para uso no injetor automático da bomba binária do GPC. 


\section{Preparação das soluções padrão}

Inicialmente foram preparadas diversas soluções estoque de deltametrina em acetato de etila. Para tanto, o padrão analítico do pesticida foi solubilizado no citado solvente, de modo a fornecer concentração exata de 1 $\mathrm{mg} \cdot \mathrm{mL}^{-1}$ (solução estoque). As soluções padrão para estudos de fortificação e injeções no sistema cromatográfico GLC/ECD foram preparadas a partir da solução estoque com diluições feitas, em ciclohexano / acetato de etila (1:1).

\section{E. Validação do método analítico}

Para os estudos de fortificação/recuperação (validação do método) as amostras (frutos, folhas) foram fortificadas, juntando-se $1 \mathrm{~mL}$ das soluções de concentrações apropriadas, obtidas por diluições sucessivas, a partir das soluções estoque, em sub-amostras de $10 \mathrm{~g}$ cada uma dos substratos obtidos de frutos ou folhas triturados/homogeneizados, sabidamente nunca anteriormente contaminados.

\section{F. Extração}

F.01. Pesar $10 \mathrm{~g}$ da amostra homogeneizada (fortificar no caso de estudar recuperação). Colocar um tubo Duran-Schott $100 \mathrm{~mL}$, juntar $50 \mathrm{~mL}$ de acetato de etila, $10 \mathrm{~g}$ de $\mathrm{Na}_{2} \mathrm{SO}_{4}$ e triturar no aparelho Ultra-turrax durante 2 minutos a $26.000 \mathrm{rpm}$.

F.02. Centrifugar a 2.500 rpm por 5 minutos para melhor separar a fase líquida do material em suspensão.

F.03. Transferir alíquota de $5 \mathrm{~mL}$ do sobrenadante (equivalente a 1 grama da amostra original) para tubo de ensaio de $12 \mathrm{~mL}$.

F.04. Evaporar em Turbo-Vap LV, em banho-maria a $30-35^{\circ} \mathrm{C}$, com auxílio de ar movente, previamente seco em filtro de sílica-gel dessecante azul 


\section{G. Limpeza}

G.01. (folhas) Preparar coluna cromatográfica montada em seringa hipodérmica de $10 \mathrm{~mL}$, com $2 \mathrm{~g}$ de SiOH (sílica gel), sobrepostos por 0,5 grama de $\mathrm{Na}_{2} \mathrm{SO}_{4}$ anidro: (i) condicionar a coluna com $10 \mathrm{~mL}$ de hexano e descartar o eluato; (ii) lavar o tubo de ensaio proviniente de F.04 com $3 \times 5 \mathrm{~mL}$ de hexano (homogeneizar em agitador Minishaker e ultra-som) e passar pela coluna; (iii) lavar a coluna com $6 \mathrm{~mL}$ de hexano / éter etílico (9:1) e descartar os eluatos; (iv) lavar a coluna com mais $2 \times 6 \mathrm{~mL}$ de hexano / éter etílico (9:1), coletar os eluatos e evaporar em Turbo-Vap LV.

G.02. (frutos e folhas) Agitar em aparelho Minishaker por cerca de 1 minuto, e deixar em ultra-som também por cerca de 1 minuto.

G.03. (folha) Ressuspender os resíduos em $10 \mathrm{~mL}$ de uma mistura de ciclohexano / acetato de etila (1:1, v/v), lavando as paredes internas do tubo de ensaio.

G.04. (fruto) Ressuspender os resíduos em $4 \mathrm{~mL}$ da mesma mistura de ciclohexano / acetato, lavando as paredes internas do tubo de ensaio.

G.05. Filtrar o extrato em filtro de membrana Millipore de malha de $0,20 \mu \mathrm{m}$, com auxílio de uma seringa hipodérmica de $5 \mathrm{~mL}$, transferindo o extrato para vials próprios de uso no GPC.

G.06. Injetar o extrato no aparelho GPC e operar o equipamento com fase móvel da mesma mistura de ciclohexano / acetato de etila, com fluxo de 1 $\mathrm{mL} \cdot \mathrm{min}^{-1}$, descartando os eluatos durante os primeiros 14 minutos e coletando a fração em eluição nos 2 minutos subseqüentes em um tubo de ensaio de $12 \mathrm{~mL}$.

G.07. Evaporar os extratos contidos nos tubos de centrífuga em TurboVap LV a $35^{\circ} \mathrm{C}$ sob leve corrente de ar movente, até secar. 


\section{H. Determinação quantitativa}

H.01. (fruto) Ressuspender os resíduos provenientes de G.07. em volume exato de $0,5 \mathrm{~mL}$ do padrão interno diluído na mistura de ciclohexano / acetato de etila (1:1).

H.01. (folha) Ressuspender os resíduos provenientes de G.07. em volume exato de $1 \mathrm{~mL}$ do padrão interno, diluído na mistura de de ciclohexano / acetato de etila (1:1).

H.02. Transferir os extratos para vials próprios de uso no injetor automático do cromatógrafo, com auxílio de pipetas de Pasteur.

H.03. Injetar alíquotas no cromatógrafo, modo "splitless pulsed", com programação linear de temperaturas (rampas).

H.04. Condições de operação do cromatógrafo:

Temperaturas:

injetor: $250^{\circ} \mathrm{C}$

coluna: $100^{\circ} \mathrm{C}$, mantém um minuto,

$280^{\circ} \mathrm{C}$, @ 23,50 C/min, mantém 12 minutos, detector: $320^{\circ} \mathrm{C}$

Fluxos dos gases:

$\mathrm{H}_{2}$ (arraste) $=6 \mathrm{~mL} \cdot \mathrm{min}^{-1}$;

$\mathrm{N}_{2}$ (make up) $=30 \mathrm{~mL} \cdot \mathrm{min}^{-1}$.

Tempo de retenção: 13 minutos 15 segundos 


\title{
I. Cálculo das porcentagens de recuperação e resíduos
}

\author{
$\%$ de recuperação $=\frac{m a m \times 100}{m t a}$, onde \\ mam = massa do analito na amostra fortificada, em ng, obtida por \\ processamento do cromatograma pelo workstation; \\ mta = massa teórica injetada do analito, em ng. \\ e \\ resíduo $\mathrm{mg} \cdot \mathrm{kg}^{-1}(\mathrm{ppm})=\frac{m p_{1} \cdot \mathrm{mam}}{m p_{2} \cdot \mathrm{Mam}}$, onde \\ $\mathrm{mp}_{1}=$ massa injetada do padrão em ng; \\ mam = massa do analito na amostra, em ng, obtida por processamento do \\ cromatograma pelo workstation; \\ $\mathrm{mp}_{2}=$ massa do analito no padrão, em ng, obtida igualmente, por \\ processamento do cromatograma pelo workstation; \\ Mam = massa da amostra injetada em mg.
}




\subsubsection{Solo}

Os estudos de resíduos de deltametrina no solo (fortificações e amostras) tiveram sua preparação, determinação quantitativa e cálculo das porcentagens de recuperação e resíduos, em tudo, muito semelhantes aos procedimentos descritos para frutos e folhas, diferindo, entretanto, quanto às etapas de extração, às quais foram executadas em extrator acelerado de solvente (marca Dionex, modelo ASE 300).

\section{A. Extração}

A.01. Tomar amostra $20 \mathrm{~g}$ de solo (seco ao ar) colocar na célula de extração, juntar $30 \mathrm{~g} \mathrm{Na}_{2} \mathrm{SO}_{4}$ suficiente para completar o volume da célula.

A.02. Extrair em ASE 300, usando-se acetato de etila, operando o aparelho a $100^{\circ} \mathrm{C}$ e pressão positiva de 1.500 psi, por cerca de 15 minutos, obtendose os extratos coletados nos frascos de uso próprio do aparelho (cerca de $120 \mathrm{~mL}$ ).

A.03. Transferir os extratos para tubo de Turbo-Vap II (marca Zymark, modelo Turbo Vap II), passando por funil contendo cerca $20 \mathrm{~g}$ de $\mathrm{Na}_{2} \mathrm{SO}_{4}$ anidro; lavar o funil com $20 \mathrm{~mL}$ de acetato de etila, recolhendo esta fração no mesmo tubo.

A.04. Concentrar até $5 \mathrm{~mL}$ a $35^{\circ} \mathrm{C}$ sob, leve fluxo de ar previamente seco em filtro de sílica gel, dessecante azul; lavar as paredes do tubo com acetato de etila e evaporar até secar.

A.05. Ressuspender em $4 \mathrm{~mL}$ de ciclohexano / acetato de etila (1:1) e transferir o extrato para tubos próprios de uso no GPC. 


\subsubsection{Resíduos deslocáveis em folhas}

O método empregado foi adaptado de IWATA et al. (1977), utilizando-se solução aquosa de Sur-Ten (sódio dioctilsulfoccinato-70\%), como solvente extrator, na diluição 1:25.000, conforme sugerido por NIGG et al. (1979). O uso deste surfactante deriva do fato de que devem ser evitados solventes orgânicos que possam extrair resíduos penetrados ou ainda carrear resíduos externos para o interior da folha.

Os equipamentos/aparelhos, os solventes/reagentes e vidrarias utilizados foram essencialmente os mesmos citados anteriormente para fruto e folha.

\section{A. Preparação das soluções padrão}

Inicialmente foi preparada solução estoque de deltametrina em acetato de etila. Para tanto, o padrão analítico do pesticida foi solubilizado no citado solvente, de modo a fornecer concentração exata de $1 \mathrm{mg} \cdot \mathrm{mL}^{-1}$ (solução estoque). As soluções padrão para estudos de fortificação e injeções no sistema cromatográfico GLC/ECD foram preparadas a partir da solução estoque com diluições feitas, em ciclohexano / acetato de etila (1:1).

\section{B. Validação do método analítico}

Para os estudos de fortificação/recuperação (validação do método) as amostras (resíduos deslocáveis em folhas) foram fortificadas, juntando-se $1 \mathrm{~mL}$ das soluções de concentrações apropriadas, obtidas por diluições sucessivas em ciclohexa/acetato de etila, a partir das solução estoque, em 40 discos foliares foram fortificadas de modo a se obter concentrações de 0,2 e $2 \mathrm{ng} \cdot \mathrm{cm}^{-2}$, com três repetições. 


\section{Extração}

C.01. Transferir a amostra de 40 discos foliares para um frasco Duran-Schott de $250 \mathrm{~mL}$ com tampa e juntar $60 \mathrm{~mL}$ da solução de Sur-ten diluída.

C.02. Agitar em mesa agitadora na velocidade de 150 ciclos.minuto $^{-1}$ durante 20 minutos e transferir o extrato, assim obtido, para um funil de separação de $250 \mathrm{~mL}$.

C.03. Juntar ao frasco Duran-Schott mais $60 \mathrm{~mL}$ de solução de Sur-ten diluída e agitar, novamente em mesa agitadora na velocidade de 150 ciclos.minuto $^{-1}$ durante 20 minutos.

C.04. Transferir o extrato para o mesmo funil de separação de $250 \mathrm{~mL}$; retirar completamente os discos foliares antes de adicionar qualquer fração de solvente orgânico.

C.05. Lavar o frasco Duran-Schott com $50 \mathrm{~mL}$ de acetato de etila, juntado ao mesmo funil de separação e tampar o funil de separação e agitar vigorosamente por 1 minuto e deixar em repouso para separação das fases.

C.06. Drenar a camada aquosa (inferior) para o frasco Duran-Schott de $250 \mathrm{~mL}$.

C.07. Drenar a camada de acetato de etila para um tubo do Turbo-Vap II, filtrando-a previamente por um funil contendo cerca de $30 \mathrm{~g}$ de $\mathrm{Na}_{2} \mathrm{SO}_{4}$ anidro.

C.08. Retornar a camada aquosa ao funil de separação e juntar mais $50 \mathrm{~mL}$ de acetato de etila e agitar vigorosamente por 1 minuto e deixar em repouso para separação das fases. Drenar a camada aquosa (inferior) para o frasco Duran-Schott de $250 \mathrm{~mL}$.

C.09. Drenar a camada de acetato de etila para o mesmo tubo do Turvo-Vap II, filtrando-a previamente pelo mesmo funil contendo $\mathrm{Na}_{2} \mathrm{SO}_{4}$ anidro.

C.10. Passar mais $20 \mathrm{~mL}$ de acetato de etila pelo funil contendo o sal, recolhendo também essa fração junto ao extrato no tubo do Turbo-Vap II.

C.11. Evaporar / concentrar em banho-maria a $35^{\circ} \mathrm{C}$ até mais ou menos $5 \mathrm{~mL}$.

C.12. Lavar as paredes internas do tubo com um pouco de acetato de etila e concentrar novamente até secar. 


\section{Limpeza}

D.01. Ressuspender os resíduos provenientes do C.12. em $2 \mathrm{~mL}$ de ciclohexano / acetato de etila (1:1).

D.02. Agitar em aparelho Minishaker por seca de 1 minuto, e deixar em ultrasom também por cerca de 1 minuto.

D.03. Filtrar o extrato em filtro de membrana Millipore de malha de $0,2 \mu \mathrm{m}$, com auxílio de uma seringa hipodérmica de $5 \mathrm{~mL}$, transferindo o extrato para vials próprios de uso no GPC e concentrar por evaporação no Turbo-Vap LV a $35^{\circ} \mathrm{C}$.

\section{E. Determinação quantitativa}

E.01. Ressuspender os resíduos provenientes de D.03. em volume exato de 0,5 $\mathrm{mL}$ de um padrão interno diluído na mistura ciclohexano / acetato de etila $(1: 1)$.

E.02. Transferir o extrato para vials próprios de uso no injetor automático do cromatógrafo, com auxílio de pipetas de Pasteur.

E.03. Injetar alíquotas no cromatógrafo, modo "splitless pulsed", com programação linear de temperaturas (rampas).

E.04. Condições de operação do cromatógrafo:

Temperaturas:

injetor: $250^{\circ} \mathrm{C}$

coluna: $100^{\circ} \mathrm{C}$, mantém um minuto, $280^{\circ} \mathrm{C}$, @ 23,5 $\mathrm{5} / \mathrm{min}$, mantém 12 minutos, detector: $320^{\circ} \mathrm{C}$

Fluxos dos gases:

$\mathrm{H}_{2}$ (arraste) $=6 \mathrm{~mL} \cdot \mathrm{min}^{-1}$;

$\mathrm{N}_{2}$ (make up) $=30 \mathrm{~mL} \cdot \mathrm{min}^{-1}$.

Tempo de retenção: 13 minutos 15 segundos 


\section{F. Cálculos das porcentagens de recuperação e resíduos}

$$
\% \text { de recuperação }=\frac{m a m \times 100}{m t a} \text {, onde }
$$
mam = massa do analito na amostra fortificadas, em ng, obtida por processamento do cromatograma pelo worksation; mta = massa teórica injetada do analito, em ng.

e

resíduo deslocável $\left(\right.$ ng. $\left.\mathrm{cm}^{-2}\right)=\frac{m p_{1} \cdot m a m}{m p_{2} \cdot A f}$, onde

$\mathrm{mp}_{1}=$ massa injetada do padrão em ng;

mam = massa do analito na amostra, em ng, obtida por processamento do cromatograma pelo workstation;

$\mathrm{mp}_{2}=$ massa do analito no padrão, em ng, obtida igualmente, por processamento do cromatograma pelo workstation;

Af = área foliar representada na injeção em $\mathrm{cm}^{2}$. 


\section{F. Análise estatísticas dos dados de resíduos deslocáveis}

Os valores de resíduos deslocáveis expressos em $\mathrm{ng} \cdot \mathrm{cm}^{-2}$ para folha foram ajustados estatisticamente por regressão não linear conforme modelo matemático proposto por Giles \& Blewet (1991), apresentado a seguir:

$$
\mathrm{Qt}=\mathrm{Qo.} \mathrm{e}^{(-\mathrm{t} / \mathrm{K})}
$$

onde:

Qt = quantidade de resíduo deslocável no tempo t;

Qo = quantidade inicial de resíduo deslocável no tempo (to);

$\mathrm{t}=$ tempo (dias);

$\mathrm{k}=$ constante do tempo.

A meia vida do resíduo deslocável de deltametrina nas folhas foi calculada através da equação:

$$
\text { meia-vida }=\ln 2 . \mathrm{K}
$$

\subsection{Avaliação da infestação da broca-das-cucurbitáceas}

Para a avaliação da ocorrência da praga e eficiência dos tratamentos com inseticidas, os 12 frutos amostrados por parcela para a análise de resíduos, foram fatiados e examinados quanto à presença ou não de danos causados pela broca. Esses dados foram anotados e transformados para serem expressos em porcentagens de frutos infestados, os quais foram à analise de variância e, em seguida, ao teste de Tukey para comparação entre os tratamentos, sendo, para tanto, usado o programa estatístico SANEST Sistema de análise estatística para o cálculo das tabelas de variância. 


\section{RESULTADOS E DISCUSSÃO}

4.1 Limites de quantificação e porcentagens de recuperação dos métodos de analises de resíduos de deltametrina em amostras de fruto, folha, solo e resíduos deslocáveis.

Os resultados obtidos nos estudos de fortificação/recuperação de deltametrina em amostras de frutos, folhas, solo e de folhas para resíduos deslocáveis encontram-se na Tabelas 2 a 5.

Tabela 2. Porcentagens (\%) de recuperação de resíduos de deltametrina em amostras fortificadas de pepino (fruto)

\begin{tabular}{ccccc}
\hline $\begin{array}{c}\text { Níveis de fortificação } \\
\text { (mg. } \mathbf{k g}^{-\mathbf{1}} \mathbf{)}(\mathbf{p p m})\end{array}$ & $\mathbf{1}$ & $\begin{array}{c}\text { Repetições (\%) } \\
\mathbf{2}\end{array}$ & $\mathbf{3}$ & $\mathbf{m} \pm \mathbf{d p}$ \\
\hline 0,02 & 75 & 78 & 72 & $75 \pm 3$ \\
0,20 & 75 & 78 & 79 & $78 \pm 2$ \\
\hline
\end{tabular}

Tabela 3. Porcentagens (\%) de recuperação de resíduos de deltametrina em amostras fortificadas de folhas de pepino

\begin{tabular}{|c|c|c|c|c|}
\hline \multirow{2}{*}{$\begin{array}{l}\text { Níveis de fortificação } \\
\left(\mathrm{mg} \cdot \mathrm{kg}^{-1}\right)(\mathrm{ppm})\end{array}$} & \multicolumn{3}{|c|}{ Repetições (\%) } & \multirow{2}{*}{$\begin{array}{c}m \pm d p \\
(\%)\end{array}$} \\
\hline & 1 & 2 & 3 & \\
\hline 0,05 & 99 & 96 & 80 & $92 \pm 10$ \\
\hline 0,50 & 96 & 80 & 73 & $80 \pm 6$ \\
\hline
\end{tabular}


Tabela 4. Porcentagens (\%) de recuperação de resíduos de deltametrina em amostras fortificadas de solo cultivado com pepino

\begin{tabular}{|c|c|c|c|c|}
\hline \multirow{2}{*}{$\begin{array}{l}\text { Níveis de fortificação } \\
\left(\mathrm{mg} \cdot \mathrm{kg}^{-1}\right)(\mathrm{ppm})\end{array}$} & \multicolumn{3}{|c|}{ Repetições (\%) } & \multirow{2}{*}{$\begin{array}{c}m \pm d p \\
(\%)\end{array}$} \\
\hline & 1 & 2 & 3 & \\
\hline 0,01 & 90 & 93 & 90 & $91 \pm 2$ \\
\hline 0,10 & 84 & 92 & 94 & $90 \pm 5$ \\
\hline
\end{tabular}

Tabela 5. Porcentagens (\%) de recuperação de resíduos de deltametrina em amostras fortificadas de folha para resíduos deslocáveis

\begin{tabular}{ccccc}
\hline $\begin{array}{c}\text { Níveis de fortificação } \\
\left.\text { (ng.cm } \mathbf{c m}^{-2}\right)\end{array}$ & $\mathbf{1}$ & $\begin{array}{c}\text { Repetições (\%) } \\
\mathbf{2}\end{array}$ & $\mathbf{3}$ & $\begin{array}{c}\mathbf{m} \pm \mathbf{d p} \\
\mathbf{( \% )}\end{array}$ \\
\hline 0,2 & 73 & 79 & 67 & $73 \pm 6$ \\
2,0 & 65 & 75 & 75 & $72 \pm 6$ \\
\hline
\end{tabular}

Cromatogramas correspondentes às fortificações dos diferentes substratos nos limites de quantificação dos métodos são apresentados nas Figuras 3 a 14. 


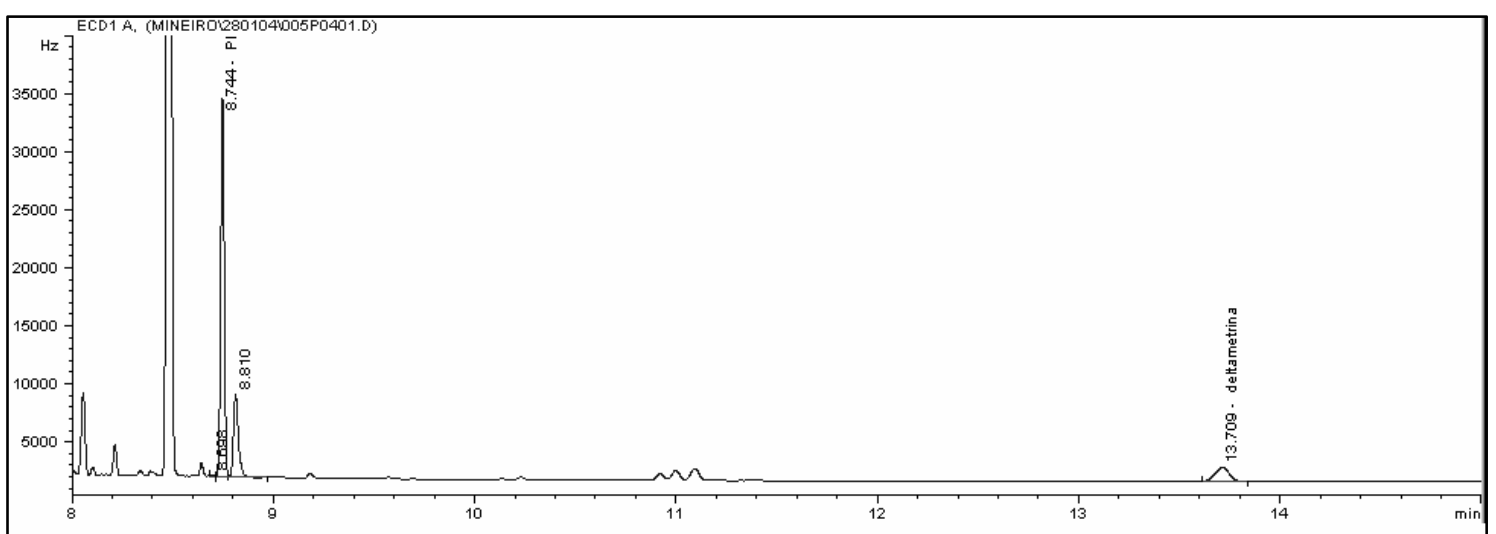

Figura 3 - Cromatograma de padrão (deltametrina) $-2 \mu \mathrm{L}-10$ pg

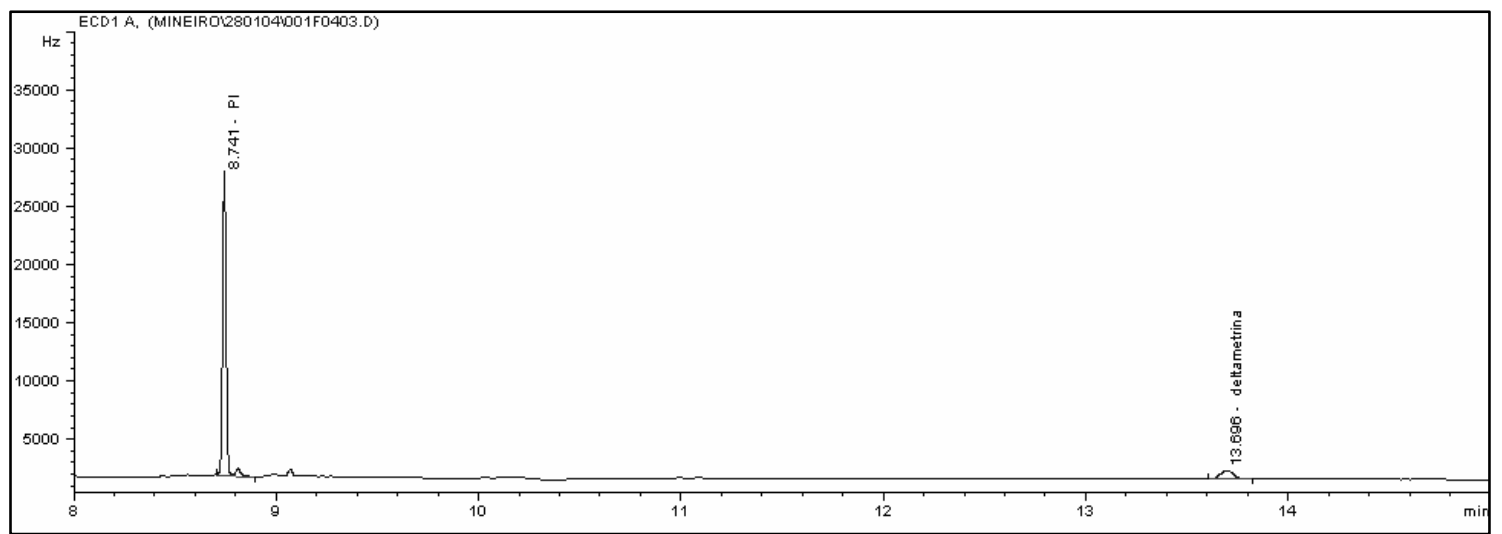

Figura 4 - Cromatograma de amostra testemunha (fruto) de pepino - $2 \mu \mathrm{L}$ - 0,5 $\mathrm{mg}$

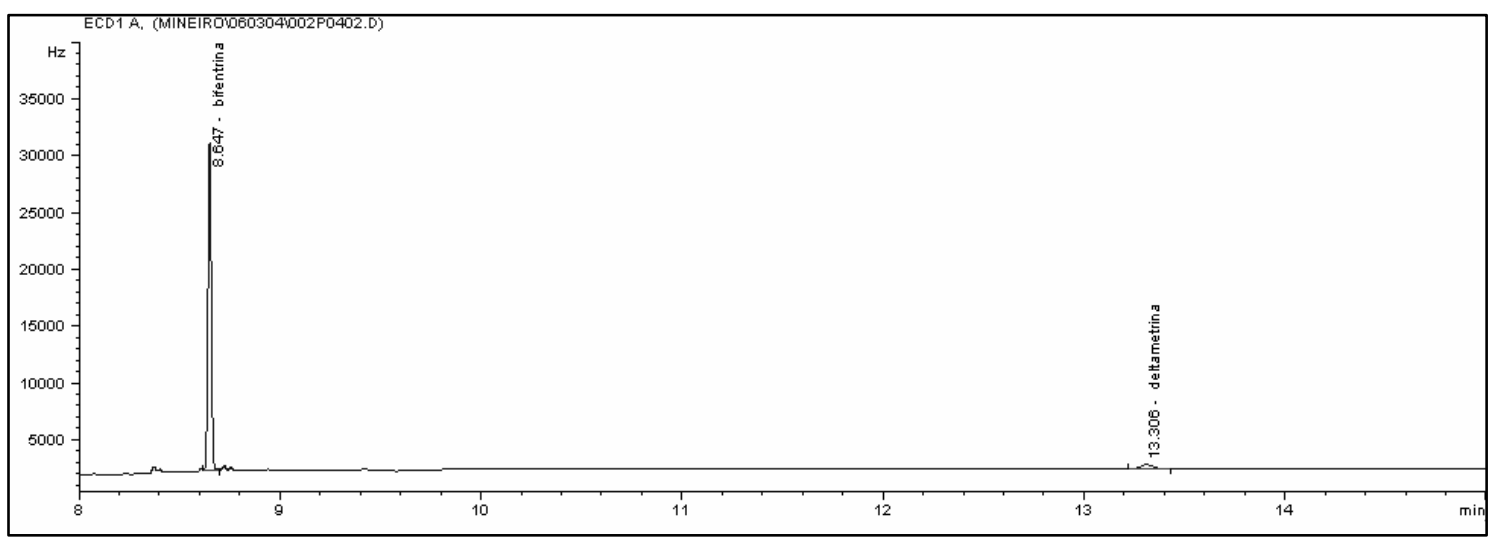

Figura 5 - Cromatograma de extrato de fruto / fortificação deltametrina.

Fortificação de 0,02 mg.kg-1 - $2 \mu \mathrm{L}-0,5 \mathrm{mg}-0,01 \mathrm{ng}(\mathrm{mt})$ 


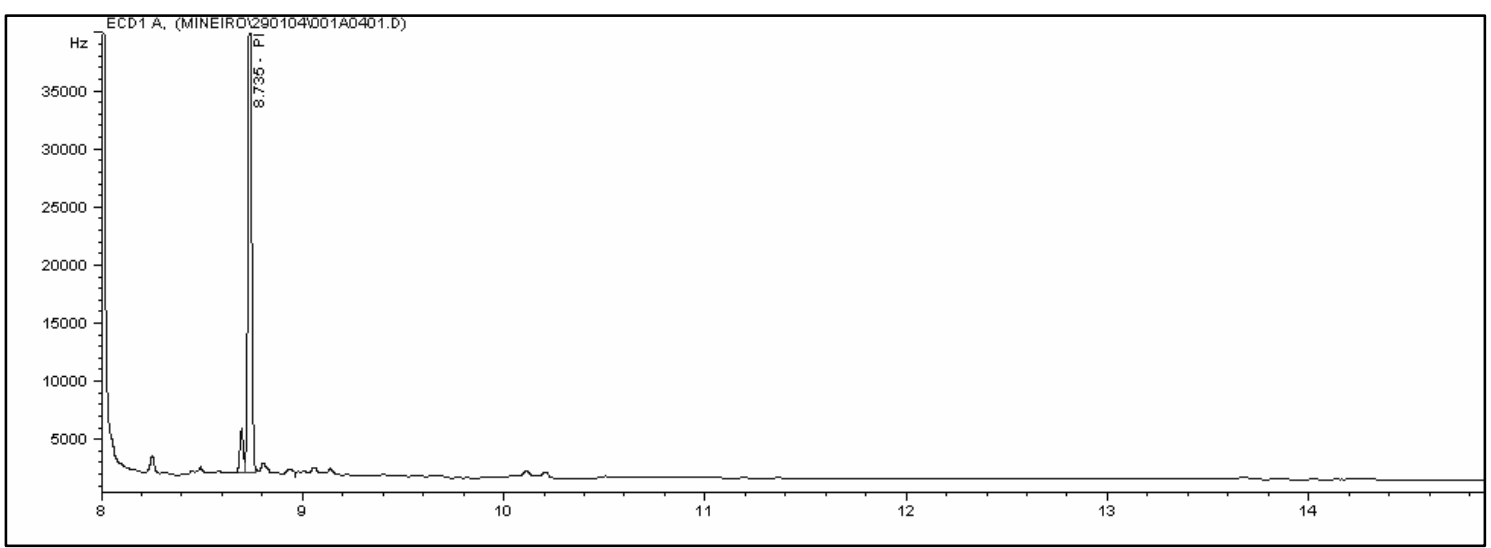

Figura 6 - Cromatograma de padrão (deltametrina) $-2 \mu \mathrm{L}-5 \mathrm{pg}$

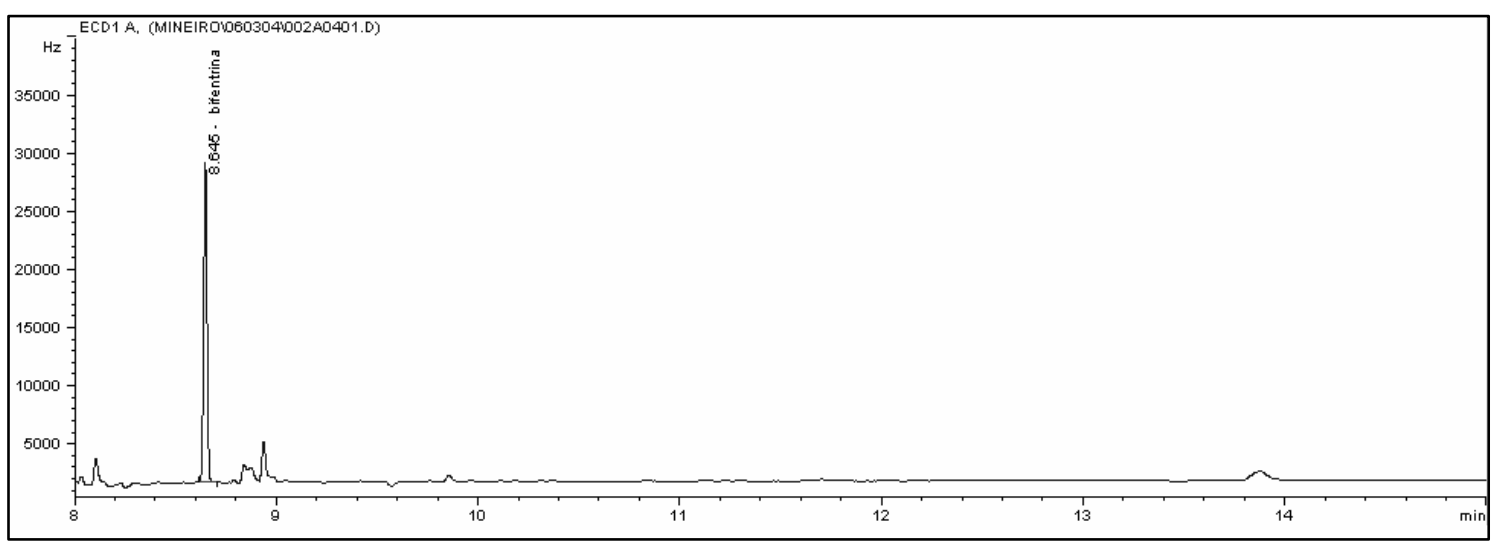

Figura 7 - Cromatograma de amostra testemunha (folha) de pepino - $2 \mu \mathrm{L}-0,1$ $\mathrm{mg}$

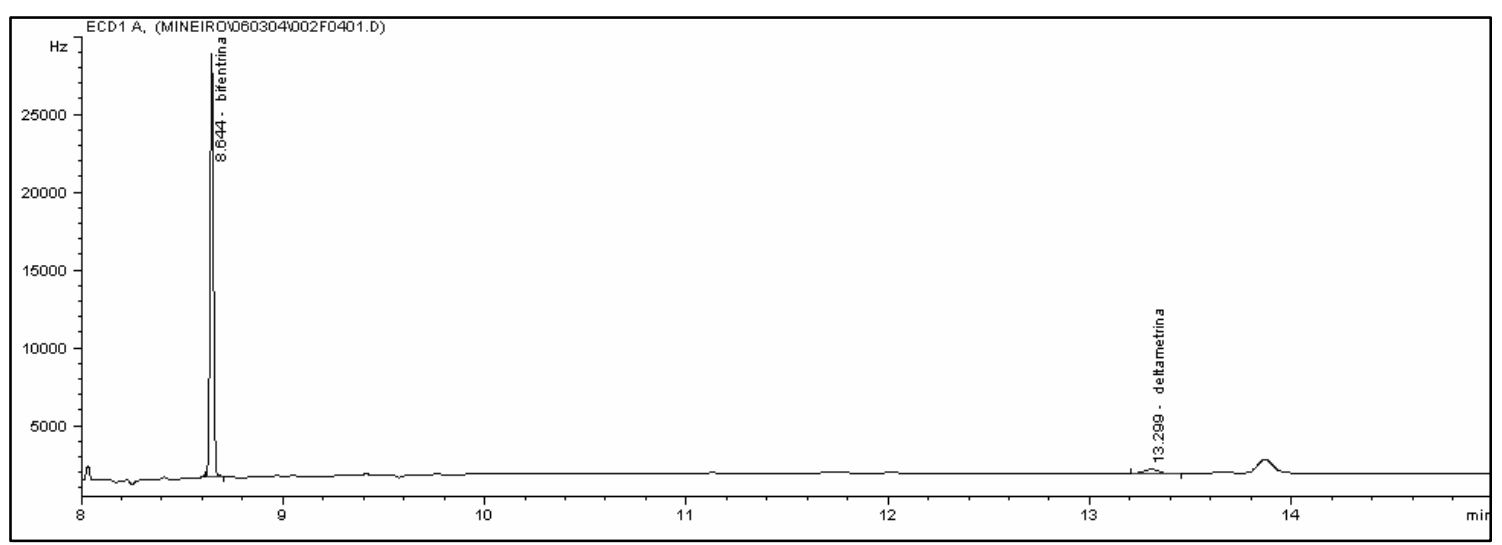

Figura 8 - Cromatograma de extrato de folha / fortificação deltametrina.

Fortificação de 0,05 mg. $\mathrm{kg}^{-1}$ - $2 \mu \mathrm{L}$ - 0,1 mg - 0,005 ng (mt) 


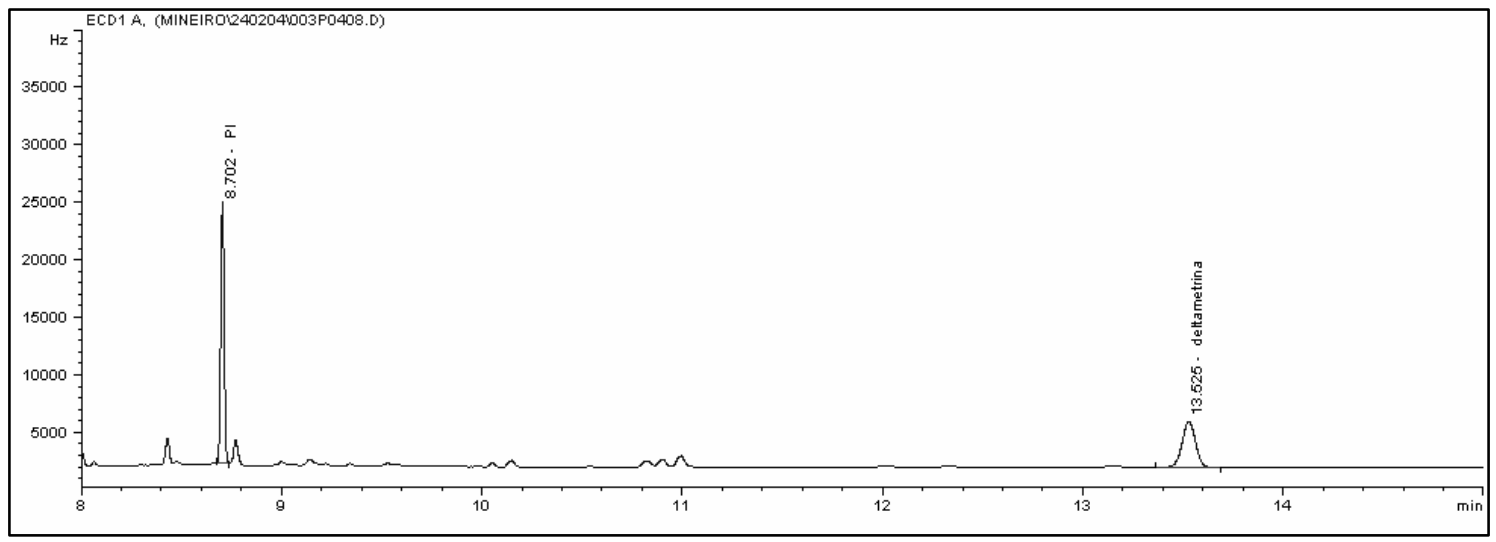

Figura 9 - Cromatograma de padrão (deltametrina) $-2 \mu \mathrm{L}-50$ pg

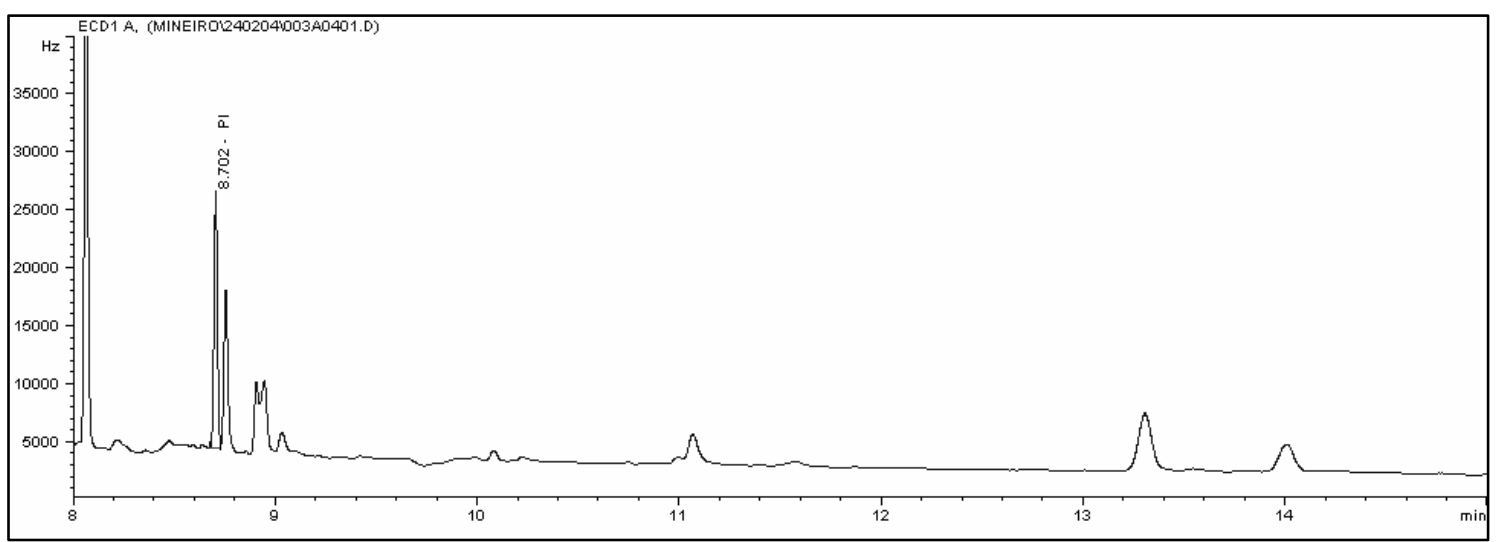

Figura 10 - Cromatograma de amostra testemunha (solo) de pepino - $2 \mu \mathrm{L}$ - 5 mg 


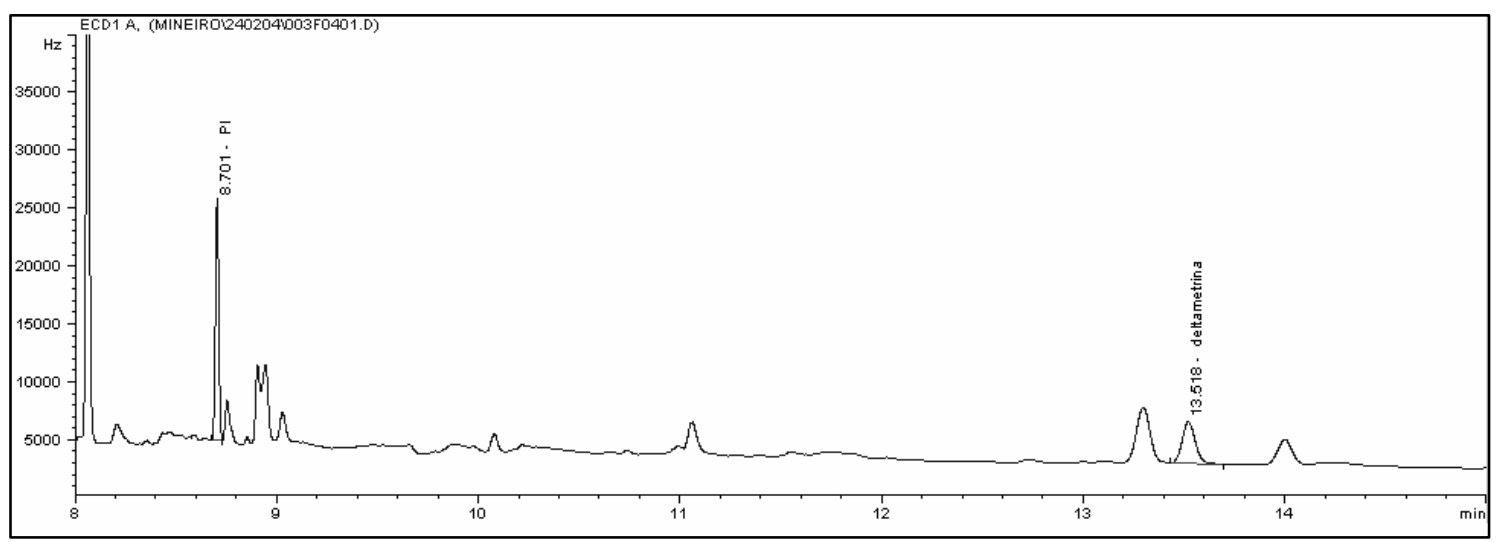

Figura 11 - Cromatograma de extrato de solo / fortificação deltametrina.

Fortificação de 0,01 mg. $\mathrm{kg}^{-1}-2 \mu \mathrm{L}-5 \mathrm{mg}-0,05 \mathrm{ng}(\mathrm{mt})$

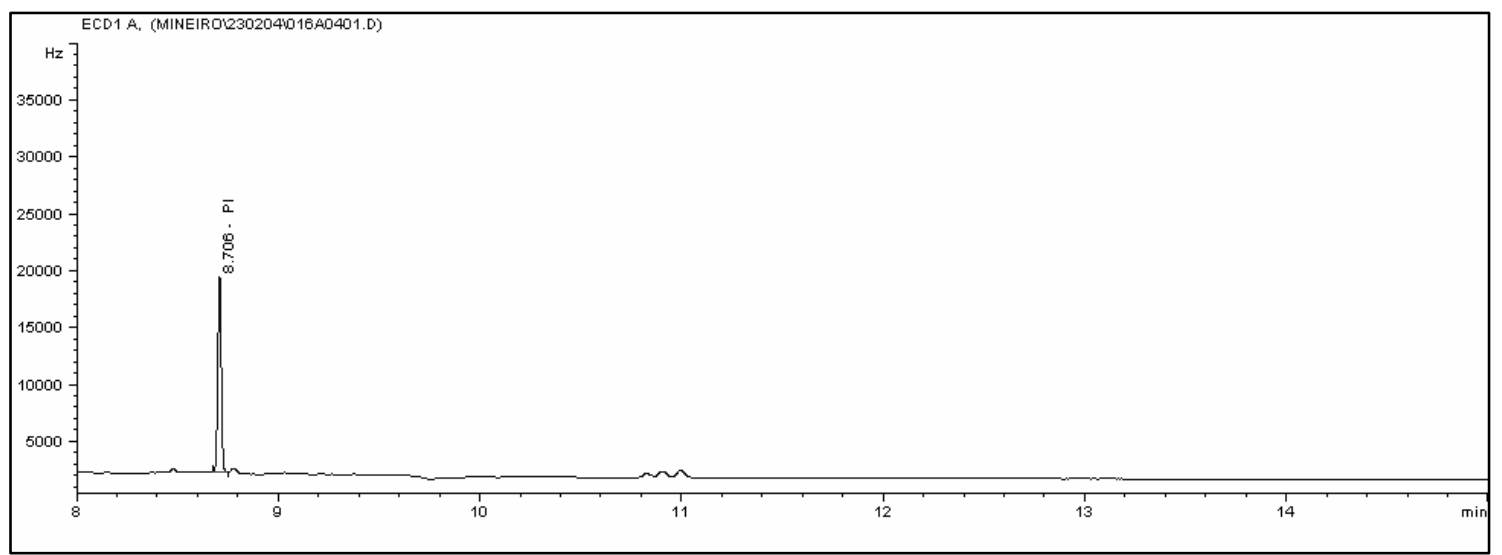

Figura 12 - Cromatograma de padrão (deltametrina) - $2 \mu \mathrm{L}-100$ pg

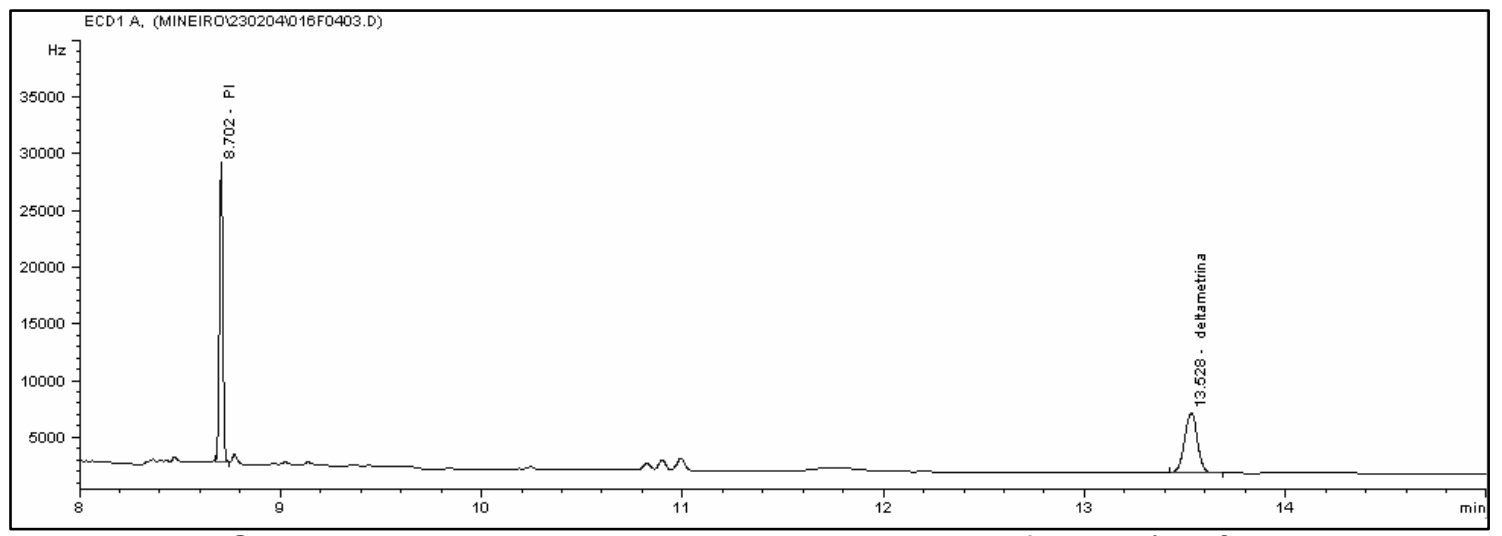

Figura 13 - Cromatograma de amostra testemunha de folhas (resíduo deslocável) de pepino - $2 \mu \mathrm{L}-392,5 \mathrm{~cm}^{2}$ 


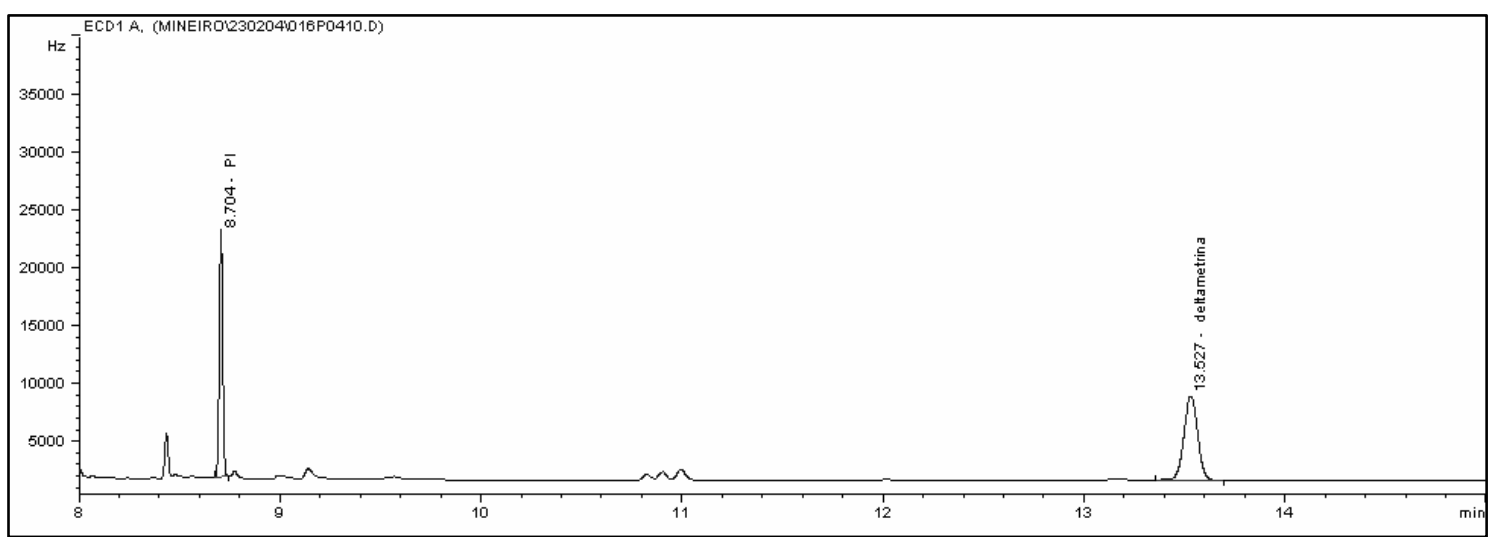

Figura 14 - Cromatograma de extrato de folhas (resíduo deslocável) de pepino / fortificação deltametrina. Fortificação de $0,2 \mathrm{ng} \cdot \mathrm{cm}^{-2}-2 \mu \mathrm{L}-392,5$ $\mathrm{cm}^{2}-78,5 \mathrm{ng}$

Nas condições experimentais, os metodos analiticos mostram-se satisfatórios para as analises de residuos de deltametrina, com limites de quantificação (LOQs) de 0,02 mg. $\mathrm{kg}^{-1}$ (ppm) em fruto, $0,05 \mathrm{mg} \cdot \mathrm{kg}^{-1}$ (ppm) em folhas, 0,01 mg. $\mathrm{kg}^{-1}$ (ppm) em solo e de $0,2 \mathrm{ng} \cdot \mathrm{cm}^{-2}$ para residuos deslocáveis nas folhas. Abaixo destes valores, os materiais interferentes, eluidos nos cromatogramas, prejudicam consideralmente a resolução destes. Desse modo, o método para análises multi-resíduos de Andersson \& Palshelden (1998), descrito para frutas e verduras (inclusive para pepino para análises de deltametrina), confirma sua aplicabilidade, bem como mostra-se, também, exeqüível para amostras folhas e de solo e para o analito em questão. Da mesma maneira, a metodologia aplicada para os resíduos deslocáveis do inseticida revelou-se adquada para as situações onde ela foi aplicada.

\subsection{Resíduos de deltametrina em frutos}

Os resultados das analises em frutos de pepino são mostrados na Tabela 6 e Figura 15 e cromatogramas típicos dessas análises são apresentados na figura 16. 
Tabela 6. Resíduos de deltametrina de diferentes formulações em frutos de pepino

\begin{tabular}{|c|c|c|c|c|c|c|}
\hline \multirow{2}{*}{ Tratamento } & \multirow{2}{*}{ DAT } & \multicolumn{3}{|c|}{ Repetições mg.kg ${ }^{-1}(\mathrm{ppm})$} & \multirow{2}{*}{$\begin{array}{l}\mathrm{m} \pm \mathrm{dp} \\
\mathrm{mg} \cdot \mathrm{kg}^{-1}\end{array}$} & \multirow{2}{*}{$\begin{array}{l}\text { Índice de } \\
\text { redução }\end{array}$} \\
\hline & & 1 & 2 & 3 & & \\
\hline \multirow{6}{*}{ Testemunha } & -1 & $<0,02$ & $<0,02$ & $<0,02$ & $<0,02$ & - \\
\hline & 0 & $<0,02$ & $<0,02$ & $<0,02$ & $<0,02$ & - \\
\hline & 1 & $<0,02$ & $<0,02$ & $<0,02$ & $<0,02$ & - \\
\hline & 3 & $<0,02$ & $<0,02$ & $<0,02$ & $<0,02$ & - \\
\hline & 5 & $<0,02$ & $<0,02$ & $<0,02$ & $<0,02$ & - \\
\hline & 7 & $<0,02$ & $<0,02$ & $<0,02$ & $<0,02$ & - \\
\hline \multirow{6}{*}{ Decis $25 \mathrm{CE}$} & -1 & $<0,02$ & $<0,02$ & $<0,02$ & $<0,02$ & - \\
\hline & 0 & 0,04 & 0,05 & 0,04 & $0,04 \pm 0,01$ & 2,0 \\
\hline & 1 & 0,03 & 0,04 & 0,03 & $0,03 \pm 0,01$ & 1,5 \\
\hline & 3 & 0,04 & 0,02 & 0,03 & $0,03 \pm 0,01$ & 1,5 \\
\hline & 5 & 0,04 & 0,03 & 0,03 & $0,03 \pm 0,01$ & 1,5 \\
\hline & 7 & 0,03 & $<0,02$ & 0,02 & $0,02 \pm 0,01$ & 1,0 \\
\hline \multirow{6}{*}{$\begin{array}{c}\text { Decis Ultra } \\
100 \mathrm{CE}\end{array}$} & -1 & $<0,02$ & $<0,02$ & $<0,02$ & $<0,02$ & - \\
\hline & 0 & 0,05 & 0,03 & 0,04 & $0,04 \pm 0,01$ & 2,0 \\
\hline & 1 & 0,04 & 0,03 & 0,04 & $0,04 \pm 0,01$ & 2,0 \\
\hline & 3 & 0,03 & 0,05 & 0,02 & $0,04 \pm 0,01$ & 2,0 \\
\hline & 5 & 0,03 & 0,04 & 0,03 & $0,04 \pm 0,01$ & 2,0 \\
\hline & 7 & 0,02 & 0,03 & $<0,02$ & $0,02 \pm 0,01$ & 1,0 \\
\hline \multirow{6}{*}{ Decis 200 SC } & -1 & $<0,02$ & $<0,02$ & $<0,02$ & $<0,02$ & - \\
\hline & 0 & 0,09 & 0,06 & 0,05 & $0,06 \pm 0,02$ & 2,0 \\
\hline & 1 & 0,06 & 0,05 & 0,07 & $0,06 \pm 0,01$ & 2,0 \\
\hline & 3 & 0,05 & 0,07 & 0,04 & $0,05 \pm 0,02$ & 1,67 \\
\hline & 5 & 0,05 & 0,03 & 0,04 & $0,04 \pm 0,01$ & 1,33 \\
\hline & 7 & 0,04 & 0,03 & 0,03 & $0,03 \pm 0,01$ & 1,0 \\
\hline
\end{tabular}




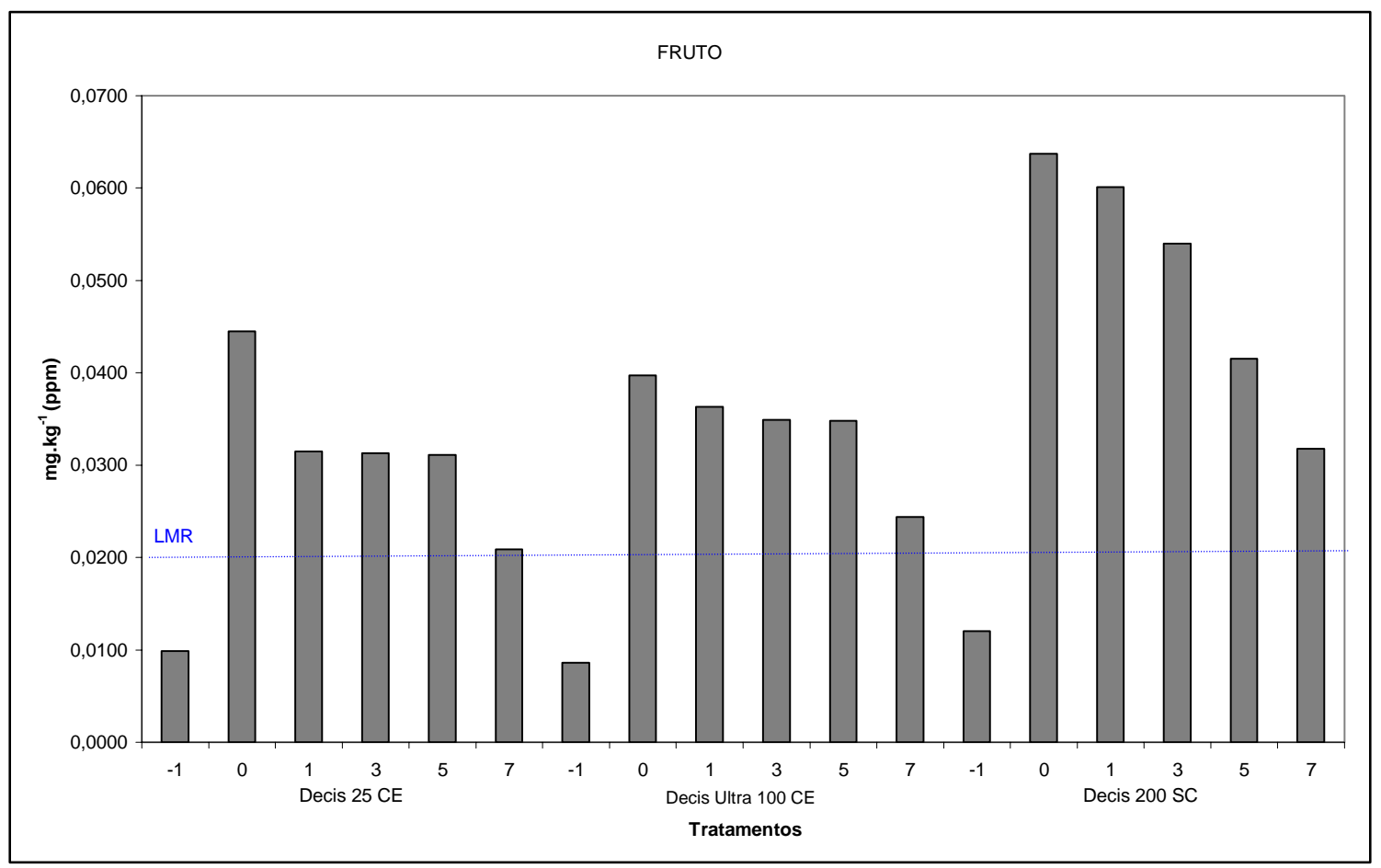

Figura 15 - Resíduos de deltametrina em cultura de pepino (fruto)

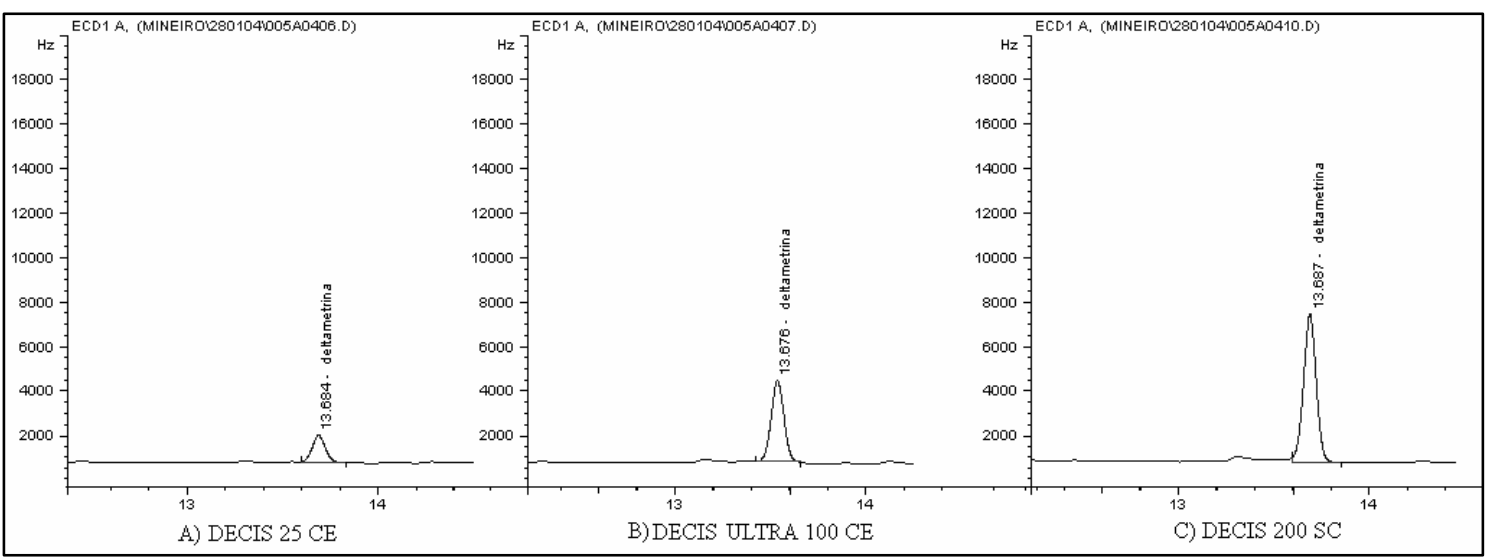

Figura 16 - Cromatogramas de extratos de amostras de fruto em diferentes tratamentos, A) 25 g i.a. $100 \mathrm{~L}^{-1}-2 \mu \mathrm{L}-0,5 \mathrm{mg}$; B) $100 \mathrm{~g}$ i.a. $100 \mathrm{~L}^{-1}$ $-2 \mu \mathrm{L}-0,5 \mathrm{mg}$; C) $200 \mathrm{~g}$ i.a. $100 \mathrm{~L}^{-1}-2 \mu \mathrm{L}-0,5 \mathrm{mg}$ 
Conforme observa-se na Tabela 6, os resíduos de deltametrina no fruto, embora em baixos níveis, encontravam-se acima do LMR de 0,03 $\mathrm{mg} \cdot \mathrm{kg}^{-1}$ mesmo um dia após o término do intervalo de segurança (2 dias) para as formulações Decis Ultra 100 CE e Decis 200 SC, sendo maiores nas amostras desta última formulação $\left(0,05 \mathrm{mg} \cdot \mathrm{kg}^{-1}\right)$. No tratamento Decis $25 \mathrm{CE}$ foram encontrados resíduos compatíveis com o LMR.

Hascoët \& André (1978) relatou nível de resíduos de deltametrina em pepino inferiores a $0,01 \mathrm{mg} \cdot \mathrm{kg}^{-1}$, que o autor considerou muito reduzido em frutos inteiros, após 2 dias decorridos da última aplicação. Também não encontrou resíduos na polpa, sendo, de ocorrência apenas na casca. Ferst (1991), pesquisando a ocorrência de resíduos de clorpirifós e fenitrotion em pepino, observou que eles foram encontrados apenas na casca, não havendo penetração na polpa.

A comparação dos níveis residuais dos tratamentos com as diferentes formulações, mostra, que a SC resultou em resíduos maiores do que as CE ao longo de todo o período de tomada das amostras, com valores ao zero dia de 0,06 mg. $\mathrm{kg}^{-1}$ para o SC e de 0,04 mg. $\mathrm{kg}^{-1}$ para as outras duas formulações, e, depois, ao final do período (7 dias) de 0,03 e 0,02 mg. $\mathrm{kg}^{-1}$, respectivamente. Tal característica de resíduos mais elevados da formulação SC foi melhor observada, quando se considera resíduos em folha e resíduos deslocáveis em folhas, como se verá adiante. Os resultados das amostras de $(-1)$ dia $(<0,02$ $\mathrm{mg} \cdot \mathrm{kg}^{-1}$ ), mostraram que o período de 7 dias foi suficiente para dissipação dos resíduos (não se caracterizando sobreposições das aplicações) e revelam que sua degradação nos diferentes tratamentos (formulações), durante o período de tomada das amostras, foi de 2 vezes para qualquer tipo de formulação (de 0,04 a $0,02 \mathrm{mg} \cdot \mathrm{kg}^{-1}$ para a 25 CE e Ultra 100 CE e de 0,06 a 0,03 mg. $\mathrm{kg}^{-1}$ para SC), o que parece evidenciar, que a ocorrência de $21,4 \mathrm{~mm}$ de chuvas durante 0 período de tomada das amostras, não foi fator determinante para uma evetual redução mais acelerada dos resíduos nos frutos. 
A observação dos valores encontrados em todas as amostras testemunhas (< LOQ), revelam que as parcelas deste tratamento foram muito bem protegidas por ocasião das aplicações, não apresentando contaminação cruzada.

\subsection{Resíduos de deltametrina em folhas}

Os resultados das analises de folha de pepino são mostrados na Tabela 7 e Figura 17. Cromatogramas típicos destas analises são apresentados na Figura 18. 
Tabela 7. Resíduos de deltametrina de diferentes formulações em folhas de pepino

\begin{tabular}{|c|c|c|c|c|c|c|}
\hline \multirow{2}{*}{ Tratamento } & \multirow{2}{*}{ DAT } & \multicolumn{3}{|c|}{ Repetições mg.kg ${ }^{-1}(\mathrm{ppm})$} & \multirow{2}{*}{$\begin{array}{l}\mathrm{m} \pm \mathrm{dp} \\
\mathrm{mg} \cdot \mathrm{kg}^{-1}\end{array}$} & \multirow{2}{*}{$\begin{array}{l}\text { Índice de } \\
\text { redução }\end{array}$} \\
\hline & & 1 & 2 & 3 & & \\
\hline \multirow{7}{*}{ Testemunha } & -1 & $<0,05$ & $<0,05$ & $<0,05$ & $<0,05$ & - \\
\hline & 0 & $<0,05$ & $<0,05$ & $<0,05$ & $<0,05$ & - \\
\hline & 1 & $<0,05$ & $<0,05$ & $<0,05$ & $<0,05$ & - \\
\hline & 3 & $<0,05$ & $<0,05$ & $<0,05$ & $<0,05$ & - \\
\hline & 5 & $<0,05$ & $<0,05$ & $<0,05$ & $<0,05$ & - \\
\hline & 7 & $<0,05$ & $<0,05$ & $<0,05$ & $<0,05$ & - \\
\hline & 14 & $<0,05$ & $<0,05$ & $<0,05$ & $<0,05$ & - \\
\hline \multirow{7}{*}{ Decis $25 \mathrm{CE}$} & -1 & 0,07 & 0,10 & 0,11 & $0,09 \pm 0,02$ & - \\
\hline & 0 & 0,79 & 0,92 & 0,87 & $0,85 \pm 0,06$ & 17,0 \\
\hline & 1 & 0,68 & 0,39 & 0,45 & $0,51 \pm 0,15$ & 10,2 \\
\hline & 3 & 0,60 & 0,38 & 0,33 & $0,44 \pm 0,14$ & 8,8 \\
\hline & 5 & 0,10 & 0,16 & 0,14 & $0,13 \pm 0,03$ & 2,6 \\
\hline & 7 & 0,07 & 0,09 & 0,05 & $0,07 \pm 0,02$ & 1,4 \\
\hline & 14 & $<0,05$ & $<0,05$ & $<0,05$ & $<0,05$ & 1,0 \\
\hline \multirow{7}{*}{$\begin{array}{c}\text { Decis Ultra } \\
100 \mathrm{CE}\end{array}$} & -1 & 0,10 & 0,10 & 0,09 & $0,09 \pm 0,01$ & - \\
\hline & 0 & 0,69 & 0,62 & 0,53 & $0,61 \pm 0,08$ & 12,2 \\
\hline & 1 & 0,38 & 0,37 & 0,49 & $0,41 \pm 0,07$ & 9,8 \\
\hline & 3 & 0,45 & 0,20 & 0,39 & $0,35 \pm 0,13$ & 7,0 \\
\hline & 5 & 0,22 & 0,23 & 0,18 & $0,21 \pm 0,03$ & 4,2 \\
\hline & 7 & 0,19 & $<0,05$ & 0,08 & $0,10 \pm 0,08$ & 2,0 \\
\hline & 14 & $<0,05$ & $<0,05$ & $<0,05$ & $<0,05$ & 1,0 \\
\hline \multirow{7}{*}{ Decis $200 \mathrm{SC}$} & -1 & 1,39 & 1,56 & 1,69 & $1,54 \pm 0,15$ & - \\
\hline & 0 & 3,33 & 5,07 & 6,07 & $4,82 \pm 1,39$ & 4,97 \\
\hline & 1 & 4,76 & 3,74 & 5,04 & $4,51 \pm 0,69$ & 4,65 \\
\hline & 3 & 5,11 & 3,62 & 3,52 & $4,08 \pm 0,89$ & 4,2 \\
\hline & 5 & 3,90 & 3,10 & 2,67 & $3,22 \pm 0,62$ & 3,31 \\
\hline & 7 & 2,66 & 2,23 & 1,90 & $2,26 \pm 0,38$ & 2,33 \\
\hline & 14 & 0,66 & 1,27 & 0,97 & $0,97 \pm 0,30$ & 1,0 \\
\hline
\end{tabular}




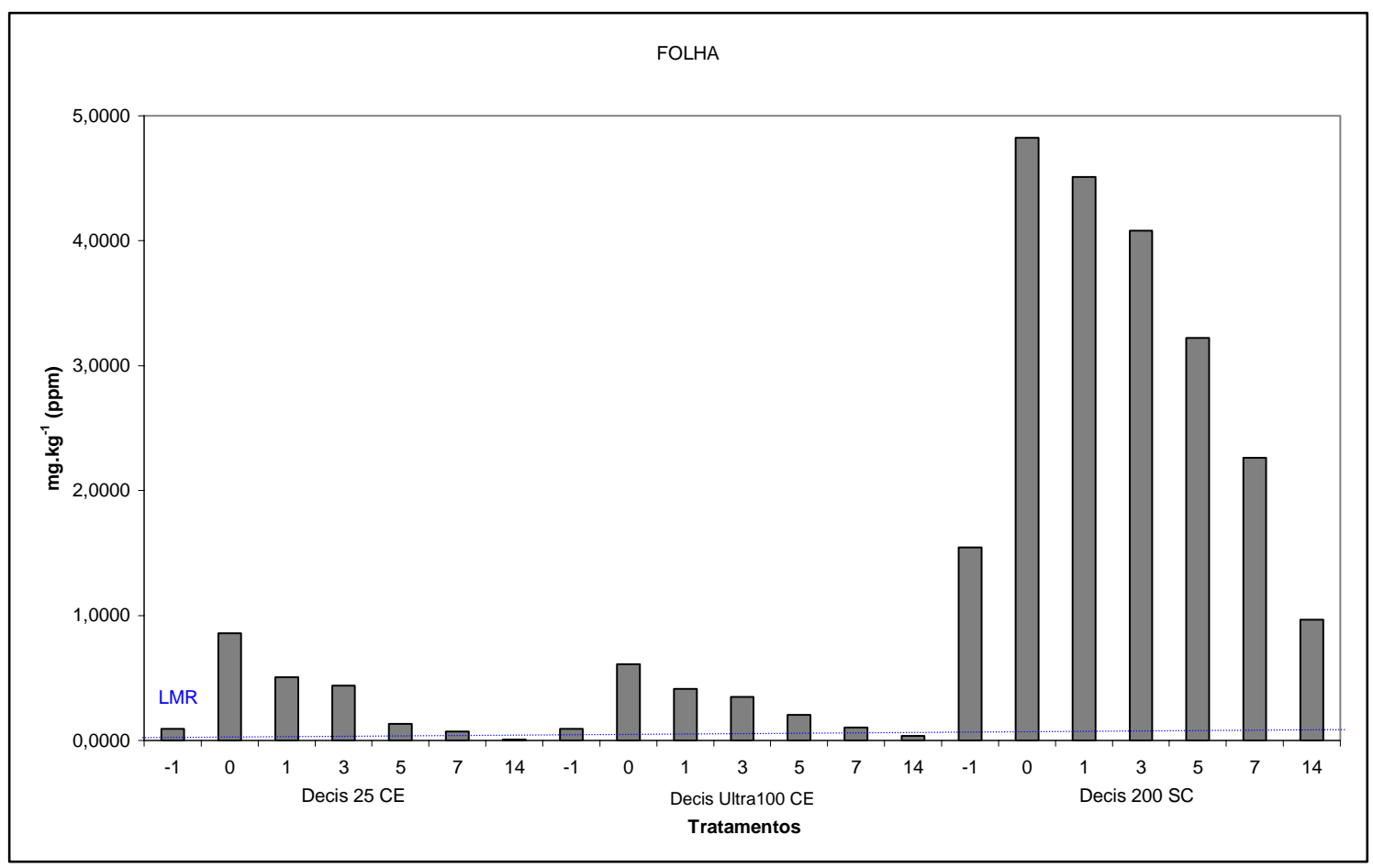

Figura 18 - Cromatogramas de extratos de amostras de folha de diferentes tratamentos, A) 25 g i.a. $100 \mathrm{~L}^{-1}-2 \mu \mathrm{L}-0,1 \mathrm{mg}$; B) $100 \mathrm{~g}$ i.a. $100 \mathrm{~L}^{-1}$ - $2 \mu \mathrm{L}-0,1 \mathrm{mg}$; C) $200 \mathrm{~g}$ i.a. $100 \mathrm{~L}^{-1}-2 \mu \mathrm{L}-0,01 \mathrm{mg}$

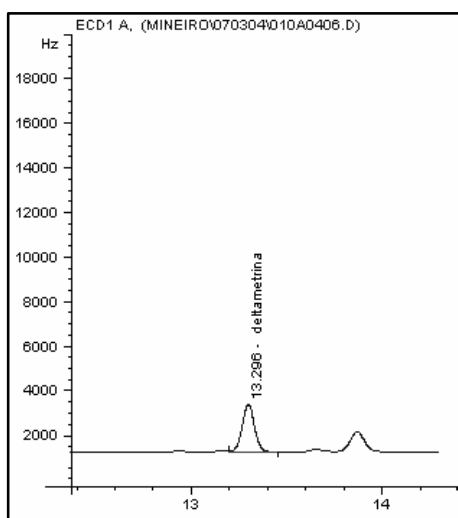

A) DECIS 25 CE

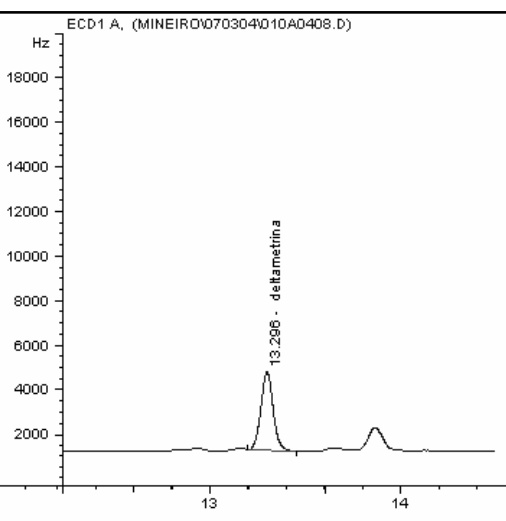

B)DECIS ULTRA $100 \mathrm{CE}$

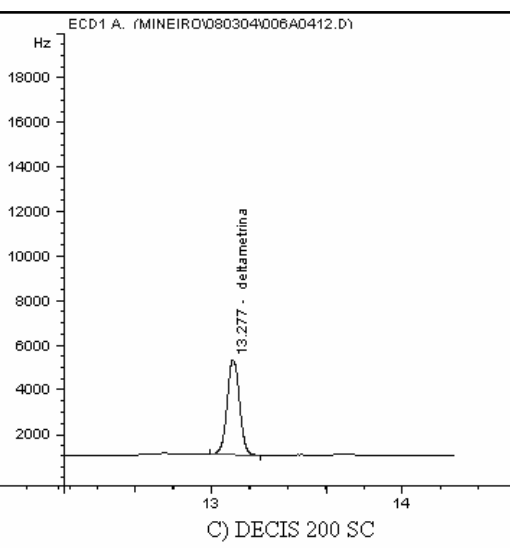

C) DECIS $200 \mathrm{SC}$

Figura 17 - Resíduos de deltametrina em cultura de pepino (folha) 
Resíduos de deltametrina foram encontrados em todas as amostras de folhas, que receberam aplicações no campo, independentemente do tipo de formulação e do dia da amostragem, inclusive nas amostras de (-1) dia.

A observação dos dados revela que os resíduos foram sempre maiores nas folhas das parcelas que receberam aplicação de SC do que de $25 \mathrm{CE}$ ou de Ultra 100 CE (esses dois últimos com resultados muito próximos), comparadas as diferentes amostragens. De fato, da formulação SC resultaram resíduos de cerca de 10-20 vezes maiores do que nas outras duas, com valores, por exemplo, ao zero dia, de 4,82 mg. $\mathrm{kg}^{-1}$ para SC, 0,85 para 25 CE e 0,61 mg. $\mathrm{kg}^{-1}$ para Ultra $100 \mathrm{CE}$; e, aos 7 dias: 2,26; 0,07 e 0,10 mg.kg ${ }^{-1}$, respectivamente. Essa grande diferença pode ser parcialmente atribuída ao fato de que as formulações CEs, pelos seus componentes emulsificantes, produzem mais cedo a saturação da folhagem, o que teria resultado em menor retenção dos CEs e, comparativamente, maior do SC. Essa maior ocorrência no SC estendeu-se até a amostragem de 14 dias, quando os resíduos nas formulações CE foram inferiores ao LOQ $\left(<0,05 \mathrm{mg}^{\mathrm{kg}}{ }^{-1}\right)$.

Da observação dos resultados nos frutos e nas folhas (Tabelas 6 e 7) observa-se que eles foram sempre maiores nestas do que naqueles, para os mesmos tratamentos (cerca de 15-80 vezes); o fato é explicado em razão da maior superfície específica que apresenta as folhas, quando comparadas com os frutos. Entretanto a degradação, dentro dos diversos tratamentos, foi, em geral, maior as folhas do que nos frutos: comparados períodos de 7 dias para ambos os substratos, a dissipação foi de cerca de 2 vezes para o SC (neste caso comparável ao fruto), 6 vezes para o Ultra 100 CE e de 12 vezes para o $25 \mathrm{CE}$, ainda relacionado ao fato da maior estabilidade do SC nas folhas. Nesse caso parece haver sido a ocorrência de chuvas no período $(21,4 \mathrm{~mm})$ importante para a maior dissipação relativa dos resíduos, uma vez que as folhas acham-se mais expostas e sujeitas à ação das precipitações atmosféricas. 
Os resultados das amostras de -1 dia $\left(1,54 \mathrm{mg} \cdot \mathrm{kg}^{-1}\right.$ para o SC, e 0,09 mg. $\mathrm{kg}^{-1}$ para ambos os CEs) mostram, evidentemente, a ocorrência dos resíduos de deltametrina superpostos de pulverizações anteriores especialmente os da formulação SC (16 vezes maiores do que as CE). Interessante notar, que a última aplicação, embora realizada na mesma dosagem nas parcelas das três formulações, não produziu os mesmos acréscimos nos diferentes tratamentos (amostras de zero dia), sendo, novamente, maiores no SC (de 1,54 a 4,82 $\mathrm{mg}^{\mathrm{kg}}{ }^{-1}$ ), do que no 25 CE (de 0,09 a $0,85 \mathrm{mg} \cdot \mathrm{kg}^{-1}$ ) e no Ultra $100 \mathrm{CE}$ (de 0,09 a $061 \mathrm{mg} \cdot \mathrm{kg}^{-1}$ ), reforçando a idéia de menor retenção nas folhas de aplicação com os CEs.

É difícil inferir sobre a contaminação do agrossistema com os restos da cultura, quanto à presença dos resíduos de deltametrina nas folhas. Muito provavelmente essa é insignificante em razão das grandezas dos resíduos encontrados, bem assim de sua dissipação.

Igualmente, como no caso de fruto, a observação de que resíduos nas amostras testemunhas formam inferiores ao LOQ $\left(<0,05 \mathrm{mg} \cdot \mathrm{kg}^{-1}\right)$, revela, novamente, que essas parcelas estiveram muito bem protegidas de contaminação cruzada.

\subsection{Resíduos de deltametrina no solo}

Os resultados das analises em solo cultivado com pepino são mostrados na Tabela 8 e 19. Cromatogramas típicos dessas analises são apresentados na Figura 20. 
Tabela 8. Resíduos de deltametrina de diferentes formulações em solo sob cultivo de pepino

\begin{tabular}{|c|c|c|c|c|c|c|}
\hline \multirow[t]{2}{*}{ Tratamento } & \multirow[t]{2}{*}{ DAT } & \multicolumn{3}{|c|}{ Repetições mg.kg ${ }^{-1}$ (ppm) } & \multirow{2}{*}{$\begin{array}{l}\mathrm{m} \pm \mathrm{dp} \\
\mathrm{mg} \cdot \mathrm{kg}^{-1}\end{array}$} & \multirow{2}{*}{$\begin{array}{l}\text { Índice de } \\
\text { redução }\end{array}$} \\
\hline & & 1 & 2 & 3 & & \\
\hline \multirow{6}{*}{ Testemunha } & -1 & $<0,01$ & $<0,01$ & $<0,01$ & $<0,01$ & - \\
\hline & 0 & $<0,01$ & $<0,01$ & $<0,01$ & $<0,01$ & - \\
\hline & 1 & $<0,01$ & $<0,01$ & $<0,01$ & $<0,01$ & - \\
\hline & 3 & $<0,01$ & $<0,01$ & $<0,01$ & $<0,01$ & - \\
\hline & 5 & $<0,01$ & $<0,01$ & $<0,01$ & $<0,01$ & - \\
\hline & 7 & $<0,01$ & $<0,01$ & $<0,01$ & $<0,01$ & - \\
\hline \multirow{6}{*}{ Decis $25 \mathrm{CE}$} & -1 & $<0,01$ & 0,01 & $<0,01$ & 0,01 & - \\
\hline & 0 & $<0,01$ & 0,02 & 0,03 & $0,02 \pm 0,01$ & 2,0 \\
\hline & 1 & 0,02 & 0,02 & 0,02 & 0,02 & 2,0 \\
\hline & 3 & 0,01 & 0,02 & 0,03 & $0,02 \pm 0,01$ & 2,0 \\
\hline & 5 & 0,01 & 0,01 & 0,02 & $0,02 \pm 0,01$ & 2,0 \\
\hline & 7 & $<0,01$ & 0,02 & $<0,01$ & $0,01 \pm 0,01$ & 1,0 \\
\hline \multirow{6}{*}{$\begin{array}{l}\text { Decis Ultra } \\
100 \mathrm{CE}\end{array}$} & -1 & 0,02 & 0,01 & 0,01 & $0,02 \pm 0,01$ & - \\
\hline & 0 & 0,07 & 0,02 & 0,02 & $0,04 \pm 0,03$ & 2,0 \\
\hline & 1 & 0,04 & 0,02 & 0,03 & $0,03 \pm 0,01$ & 1,5 \\
\hline & 3 & 0,04 & $<0,01$ & 0,02 & $0,03 \pm 0,02$ & 1,5 \\
\hline & 5 & 0,03 & 0,02 & 0,01 & $0,02 \pm 0,10$ & 1,0 \\
\hline & 7 & 0,03 & 0,01 & 0,02 & $0,02 \pm 0,01$ & 1,0 \\
\hline \multirow{6}{*}{ Decis 200 SC } & -1 & 0,02 & 0,03 & 0,02 & $0,02 \pm 0,01$ & - \\
\hline & 0 & 0,03 & 0,10 & 0,03 & $0,05 \pm 0,04$ & 2,5 \\
\hline & 1 & 0,08 & 0,03 & 0,03 & $0,05 \pm 0,03$ & 2,5 \\
\hline & 3 & 0,03 & 0,05 & 0,04 & $0,04 \pm 0,01$ & 2,0 \\
\hline & 5 & 0,05 & 0,03 & 0,03 & $0,04 \pm 0,01$ & 2,0 \\
\hline & 7 & 0,01 & 0,02 & 0,03 & $0,02 \pm 0,01$ & 1,0 \\
\hline
\end{tabular}




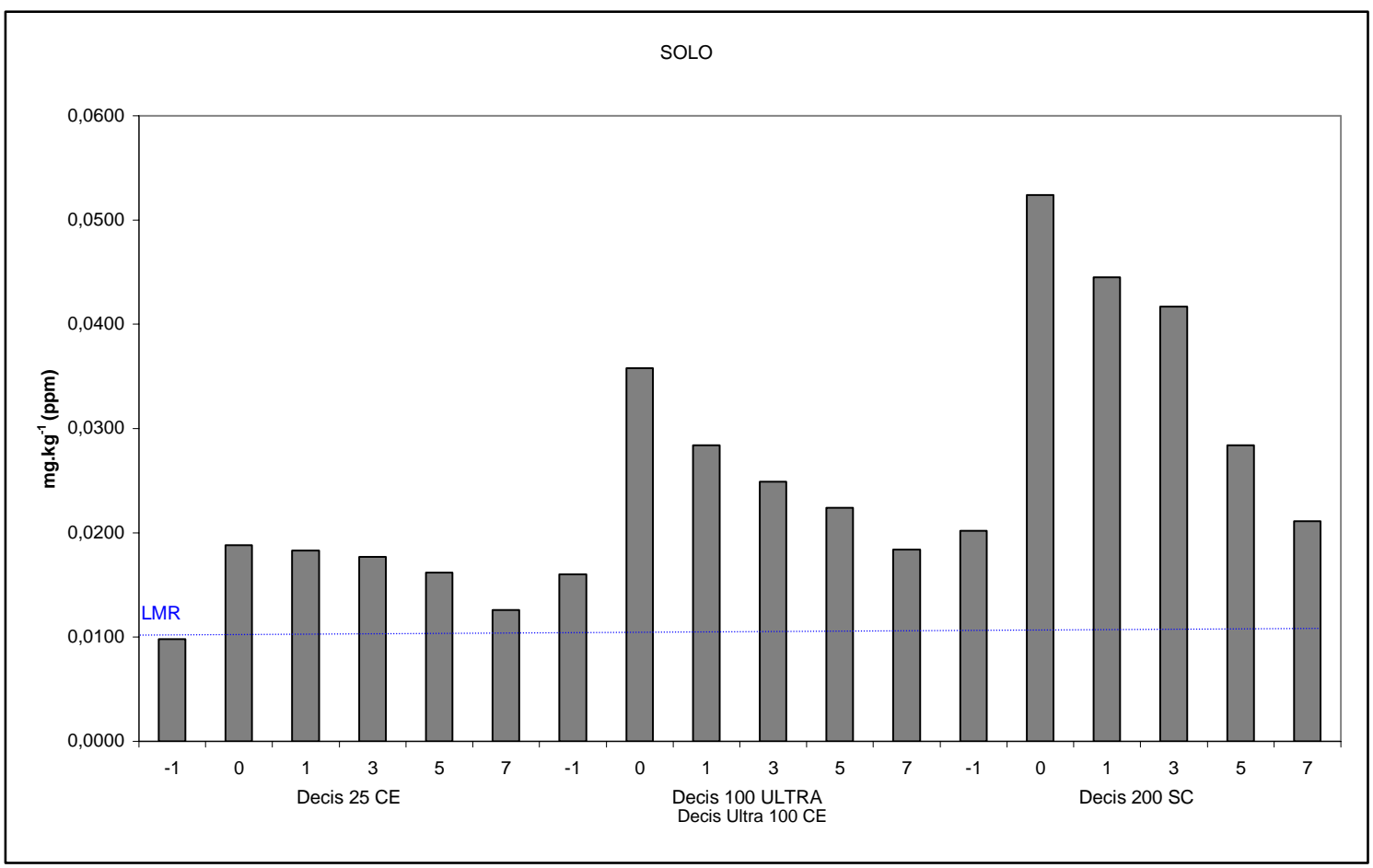

Figura 19 - Resíduos de deltametrina em cultura de pepino (solo)

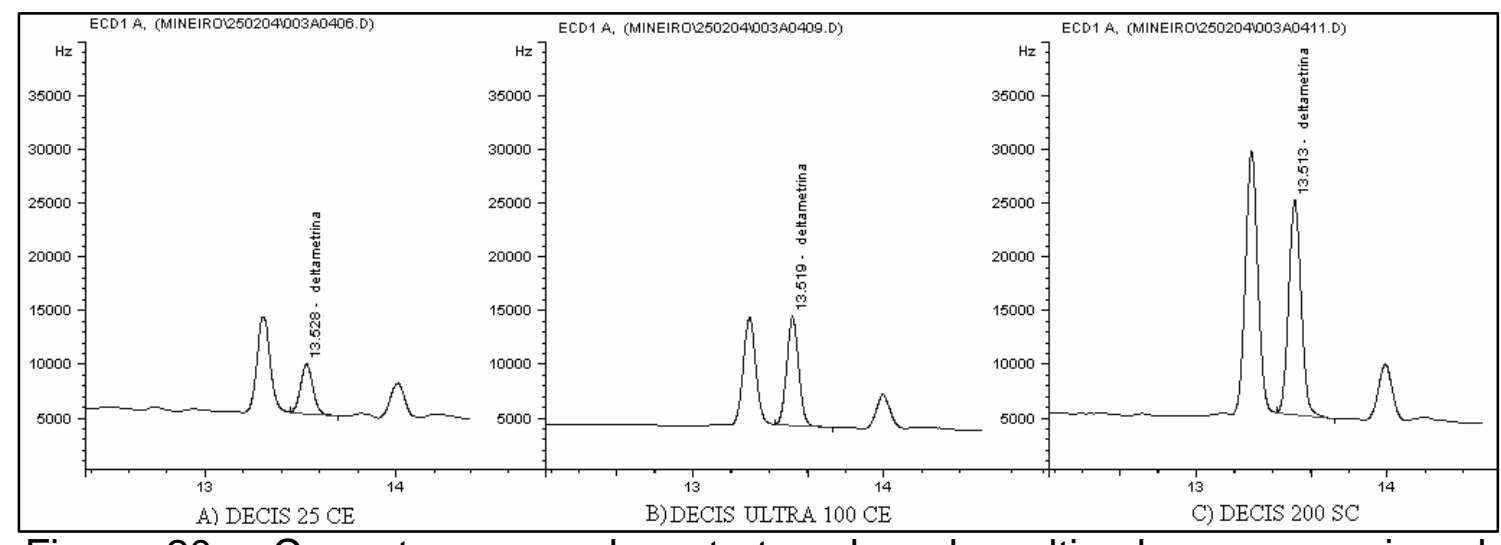

Figura 20 - Cromatogramas de extratos de solo cultivados com pepino de diferentes tratamentos, A) $25 \mathrm{~g}$ i.a. $100 \mathrm{~L}^{-1}-2 \mu \mathrm{L}-5 \mathrm{mg}$; B) $100 \mathrm{~g}$ i.a. $100 \mathrm{~L}^{-1}-2 \mu \mathrm{L}-5 \mathrm{mg}$; C) $200 \mathrm{~g}$ i.a. $100 \mathrm{~L}^{-1}-2 \mu \mathrm{L}-5 \mathrm{mg}$ 
Resíduos de deltametrina foram encontrados em todas as amostras de solo, em que vegetavam plantas de pepino, que receberam aplicações no campo, independentemente do tipo de formulação e do dia da amostragem, inclusive nas amostras de (-1) dia.

Carvalho (2003), trabalhando em programação semelhante, encontrou, também, resíduos do inseticida no solo. Entretanto, os níveis, em todos os tratamentos e amostragens, revelaram-se baixos, variáveis de 0,01-0,05 mg. $\mathrm{kg}^{-1}$ nas amostras dos tratamentos colhidas após a última aplicação de deltametrina (zero-7 dias), estando as grandezas dos resíduos encontrados bem próximos daquelas obtidas pela autora.

A comparação dos dados dos tratamentos com as diferentes formulações mostra que, para o solo, os resíduos resultantes da formulação SC, embora também maiores do que os das CE, foram, neste caso, mais próximos entre si. É, também, difícil observar tendências nas intensidades de dissipação, contando-se com tais valores baixos, mas é possível observar que pelo menos no período dos primeiros 5 dias decorridos da última aplicação, tal intensidade foi de cerca de 1-2 vezes para os diversos tratamentos, o que pode ser explicado pela baixíssima solubilidade da deltametrina em água de $<0,2 \mu \mathrm{g} \cdot \mathrm{L}^{-1}$ a $25^{\circ} \mathrm{C}$ (Tomlin, 1995), o que dificulta sua percolação no perfil do solo, fazendose supor que os resíduos, assim, permanecem na superfície deste.

O resultado das amostras de $(-1)$ dia de $0,02 \mathrm{mg} \cdot \mathrm{kg}^{-1}$ para os três tratamentos com deltametrina mostra pequena sobreposição das duas pulverizações anteriores. Evidentemente, o solo foi contaminado por escorrimento da calda, após saturação das folhas. 


\subsection{Resíduos deslocáveis de deltametrina em folhas}

Os resultados obtidos das analises de resíduos deslocáveis em folhas de

pepino acham-se na Tabela 9 e figura 21. Cromatogramas típicos dessas análises são apresentados nas Figuras 22, 23 e 24. 
Tabela 9. Resíduos deslocáveis de deltametrina de diferentes formulações em folhas de pepino

\begin{tabular}{|c|c|c|c|c|c|c|}
\hline \multirow{2}{*}{ Tratamento } & \multirow{2}{*}{ DAT } & \multicolumn{3}{|c|}{ Repetições ng.cm-2 } & \multirow{2}{*}{$\begin{array}{l}\mathrm{m} \pm \mathrm{dp} \\
\mathrm{ng} . \mathrm{cm}^{-2}\end{array}$} & \multirow{2}{*}{$\begin{array}{c}\text { Índice de } \\
\text { redução }\end{array}$} \\
\hline & & 1 & 2 & 3 & & \\
\hline \multirow{7}{*}{ Testemunha } & -1 & $<0,2$ & $<0,2$ & $<0,2$ & $<0,2$ & - \\
\hline & 0 & $<0,2$ & $<0,2$ & $<0,2$ & $<0,2$ & - \\
\hline & 1 & $<0,2$ & $<0,2$ & $<0,2$ & $<0,2$ & - \\
\hline & 3 & $<0,2$ & $<0,2$ & $<0,2$ & $<0,2$ & - \\
\hline & 5 & $<0,2$ & $<0,2$ & $<0,2$ & $<0,2$ & - \\
\hline & 7 & $<0,2$ & $<0,2$ & $<0,2$ & $<0,2$ & - \\
\hline & 14 & $<0,2$ & $<0,2$ & $<0,2$ & $<0,2$ & - \\
\hline \multirow{7}{*}{ Decis $25 \mathrm{CE}$} & -1 & $<0,2$ & $<0,2$ & 1,0 & 0,4 & - \\
\hline & 0 & 8,0 & 6,0 & 6,0 & $7 \pm 1,2$ & 7,0 \\
\hline & 1 & 3,0 & 3,0 & 3,0 & 3 & 3,0 \\
\hline & 3 & 2,0 & 2,0 & 4,0 & $3 \pm 1,2$ & 3,0 \\
\hline & 5 & 2,0 & 1,0 & 2,0 & $2 \pm 0,6$ & 2,0 \\
\hline & 7 & 1,0 & 1,0 & 2,0 & $1 \pm 0,6$ & 1,0 \\
\hline & 14 & 1,0 & 1,0 & 1,0 & 1 & 1,0 \\
\hline \multirow{7}{*}{$\begin{array}{c}\text { Decis Ultra } \\
100 \mathrm{CE}\end{array}$} & -1 & 1,0 & $<0,2$ & $<0,2$ & 0,4 & - \\
\hline & 0 & 6,0 & 5,0 & 5,0 & $5 \pm 0,6$ & 5,0 \\
\hline & 1 & 2,0 & 4,0 & 3,0 & $3 \pm 1,0$ & 3,0 \\
\hline & 3 & 3,0 & 3,0 & 4,0 & $3 \pm 0,6$ & 3,0 \\
\hline & 5 & 3,0 & 2,0 & 1,0 & $2 \pm 1,0$ & 2,0 \\
\hline & 7 & 1,0 & 2,0 & 2,0 & $2 \pm 0,6$ & 2,0 \\
\hline & 14 & 1,0 & 1,0 & 1,0 & 1 & 1,0 \\
\hline \multirow{7}{*}{ Decis 200 SC } & -1 & 11,0 & 11,0 & 9,0 & $10,3 \pm 1,2$ & - \\
\hline & 0 & 37,0 & 22,0 & 23,0 & $27,3 \pm 8,4$ & 1,58 \\
\hline & 1 & 26,0 & 23,0 & 32,0 & $27,0 \pm 4,6$ & 1,56 \\
\hline & 3 & 32,0 & 22,0 & 23,0 & $25,7 \pm 5,5$ & 1,48 \\
\hline & 5 & 34,0 & 17,0 & 19,0 & $23,3 \pm 9,3$ & 1,35 \\
\hline & 7 & 24,0 & 24,0 & 21,0 & $23,0 \pm 1,7$ & 1,33 \\
\hline & 14 & 19,0 & 14,0 & 19,0 & $17,3 \pm 2,9$ & 1,0 \\
\hline
\end{tabular}




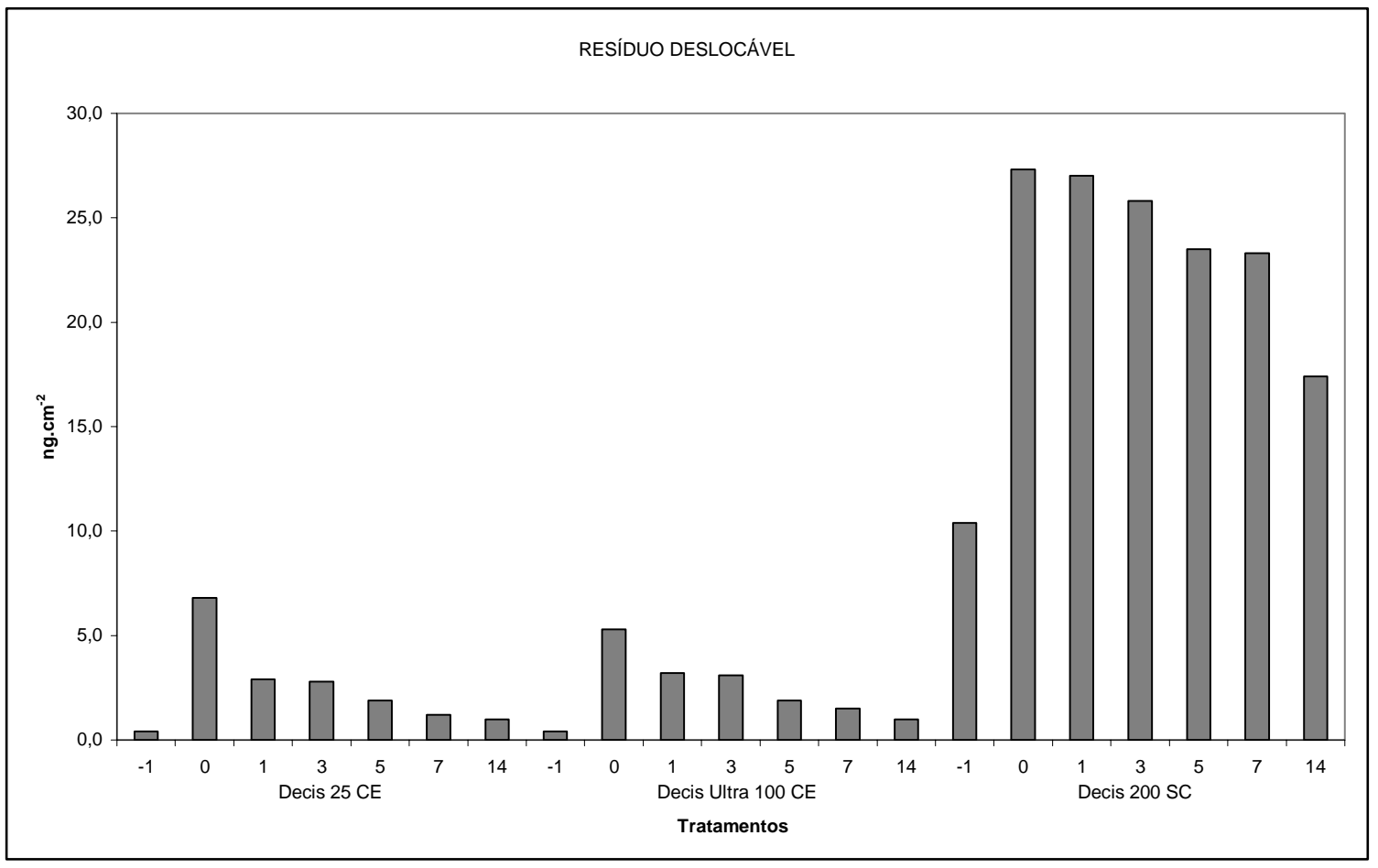

Figura 21 - Resíduos de deltametrina em cultura de pepino (folhas - resíduo deslocável)

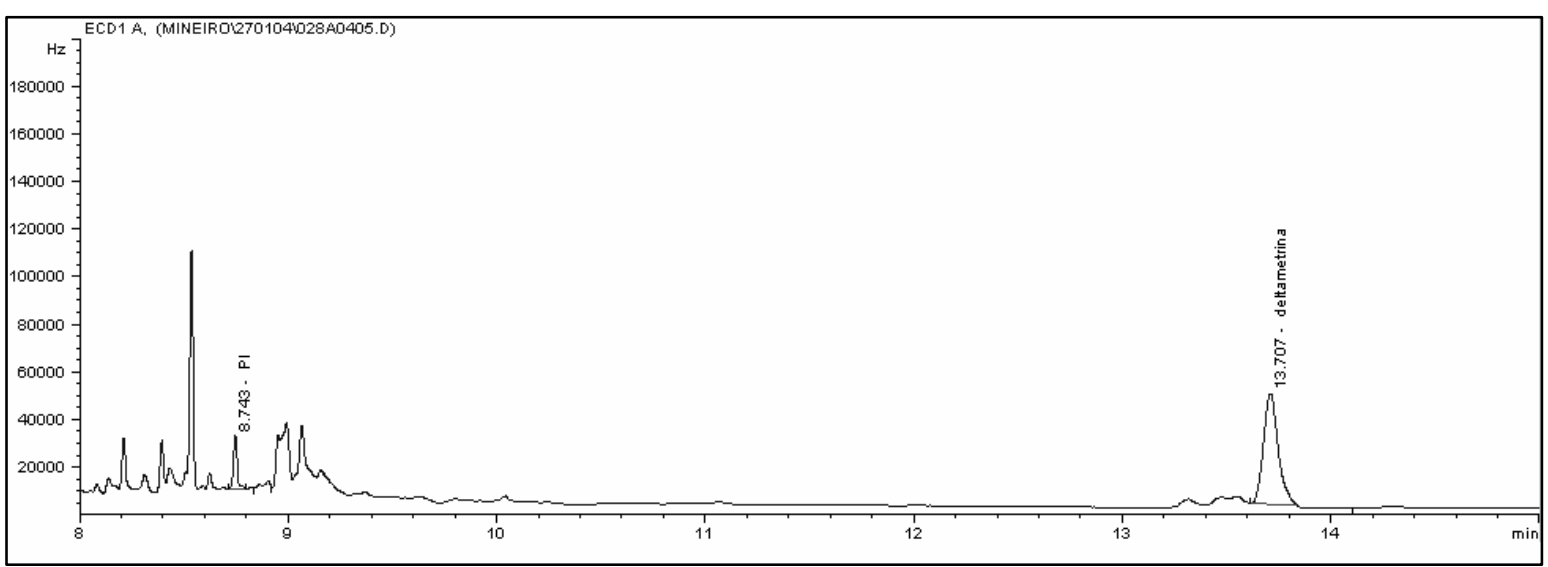

Figura 22 - Cromatograma de amostra tratamento 25 g i.a. $100 \mathrm{~L}^{-1}$ em folha (resíduo deslocável) - (deltametrina - Decis 25 CE) - $2 \mu \mathrm{L}-392,5$ $\mathrm{cm}^{2}$ 


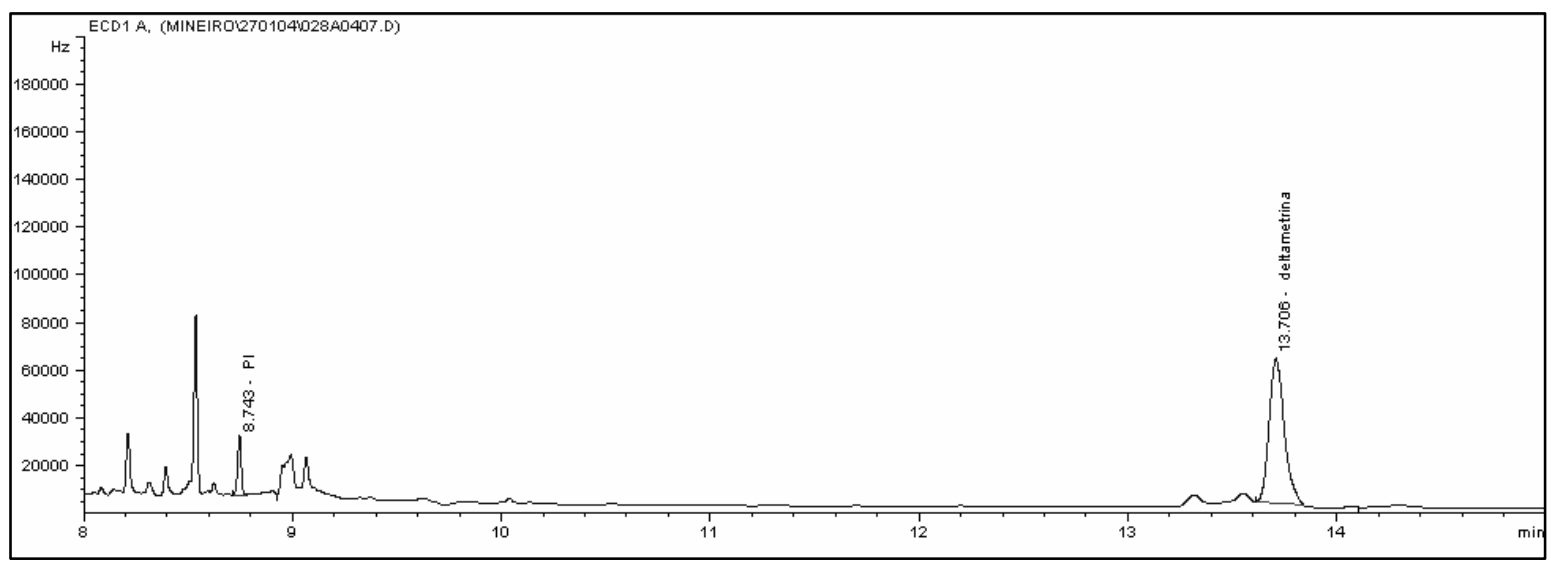

Figura 23 - Cromatograma de amostra tratamento 100 g i.a. $100 \mathrm{~L}^{-1} \mathrm{em}$ folha (resíduo deslocável) - (deltametrina - Decis Ultra 100 CE) - $2 \mu \mathrm{L}$ $392,5 \mathrm{~cm}^{2}$

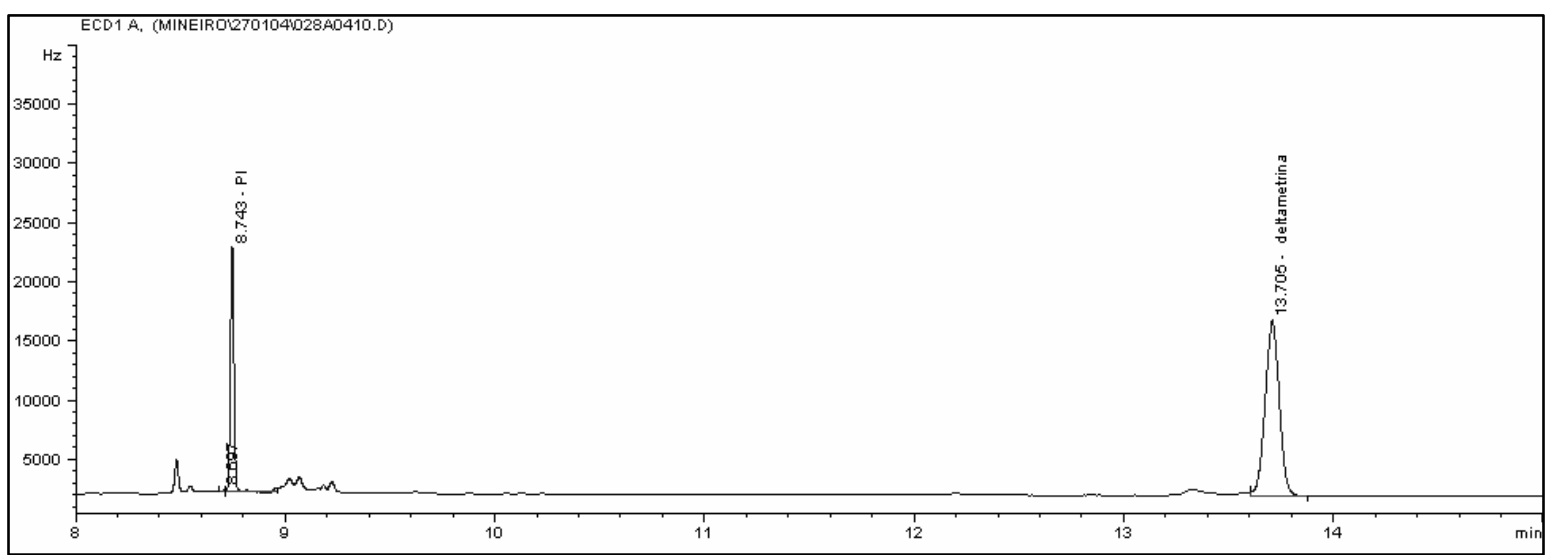

Figura 24 - Cromatograma de amostra tratamento $200 \mathrm{~g}$ i.a. $100 \mathrm{~L}^{-1} \mathrm{em}$ folha (resíduo deslocável) - (deltametrina - Decis 200 SC) - $2 \mu \mathrm{L}$ - 0,3925 $\mathrm{cm}^{2}$

Os parâmetros Qo e $\mathrm{K}$ estimados pelo modelo matemático e que representam a curva de degradação para cada tratamento, bem como os valores de $R^{2}$ para as equações ajustadas são apresentadas na Tabela 10. 
Tabela 10. Valores de depósito inicial (Qo), constante do tempo (K) e coeficiente de correlação $\left(\mathrm{R}^{2}\right)$, estimados por regressão não linear para os tratamentos para as amostras de folhas

\begin{tabular}{lccc}
\hline \multicolumn{1}{c}{ Tratamento } & Qo & $\mathbf{K}$ & $\mathbf{R}^{\mathbf{2}}$ \\
\hline Decis 25 CE & $6,680( \pm 0,059)$ & $3,973( \pm 2,223)$ & $77 \%$ \\
Decis Ultra 100 CE & $5,330( \pm 0,015)$ & $5,520( \pm 2,427)$ & $89 \%$ \\
Decis 200 SC & $27,332( \pm 0,003)$ & $46,435( \pm 20,844)$ & $81 \%$ \\
\hline
\end{tabular}

valores entre parênteses correspondem aos erros padrões das estimativas

Os dados dos resíduos deslocáveis foram bem representados pelas curvas de degradação, como indicam os altos valores de $R^{2}$. Com as equações de regressão para os diversos tratamentos foram construídas as Figuras 25, 26 e 27, bem como calculados os valores de meias-vida desses resíduos deslocáveis para as três formulações.

Da observação da Tabela 9 e Figura 21 verifica-se que os resíduos deslocáveis de deltametrina nas folhas foram muito maiores nas amostras provenientes de aplicações em SC, quando comparadas com as formulações CE de cerca de 4-20 vezes; entre as formulações CE os níveis residuais foram muito semelhantes em todo o período de tomada das amostras (14 dias). Interessante notar que tais níveis maiores de resíduos deslocáveis no SC tornaram-se mais evidentes ao final do período de amostragem, quando comparativamente foram cerca de 20 vezes mais elevados. A razão desses teores maiores em SC deve-se ao fato dos componentes da formulação tornaram-na mais hidrofílica do que as CE, que, pelos seus componentes é relativamente mais lipofílica e, por isso mesmo mais capazes de penetrar nas camadas cerosas das folhas, tornando os resíduos menos disponíveis para a transferência ao corpo do trabalhador. Nessas condições os valores de meias- 
vida encontrados foram de 2,8, 3,8 e 32,2 dias, respectivamente para o Decis 25 CE, Decis Ultra 100 CE e Decis 200 SC.

Os resultados também indicam ter havido sobreposição de aplicações anteriores com níveis maiores (25 vezes) no SC $\left(10,4 \mathrm{ng} . \mathrm{cm}^{-2}\right)$, comparado com os CEs $\left(0,4 \mathrm{ng} \cdot \mathrm{cm}^{-2}\right)$. A ultima aplicação, entretanto, resultou, em valores proporcionais, maior incremento dos resíduos deslocáveis nos CEs (13 e 17 vezes, para o 25 CE e Ultra $100 \mathrm{CE}$, respectivamente) e menor para a SC (2,5 vezes), porem, em termos absolutos, os acréscimos foram, respectivamente : 6,$4 ; 4,9$ e $17 \mathrm{ng} \cdot \mathrm{cm}^{-2}$.

Durante o período de coleta, em relação aos resíduos deslocáveis de zero a 14 dias, as dissipações foram de : 7; 5 e 1,58, respectivamente para o 25 CE, Ultra 100 CE e SC, indicando que os de origem da aplicação SC, além de serem mais elevados, dissipam-se, ainda, mais lentamente.

Evaristo (1994) observou que resíduos deslocáveis de metamidofós decresceram em folhas de tomate rapidamente, tendo explicado o fato em razão da alta solubilidade do metamidofós em água e sua grande volatilidade. A menor dissipação da deltametrina deve-se, também às mesmas propriedades físico-químicas, porém de características opostas, isto é: baixíssima solubilidade em água $\left(<0,2 \mu \mathrm{g} \cdot \mathrm{L}^{-1}-25^{\circ} \mathrm{C}\right)$ e baixa volatilidade $\left(\mathrm{Vp}<1,33 \cdot 10^{-5}\right.$ $\left.\mathrm{Pa}-25^{\circ} \mathrm{C}\right)$, como relata Tomlin (1995) .

O risco que representa a exposição ocupacional de trabalhadores rurais a tais níveis de resíduos deslocáveis de deltametrina é difícil de ser corretamente antecipado; ele é suposto ser pequeno, dada a sua baixa toxicidade dérmica de $\left(\mathrm{DL}_{50}>2000 \mathrm{mg} \cdot \mathrm{kg}^{-1}\right)$, segundo Tomlin (1995); porém deve-se ressaltar a importância do uso de EPIs (equipamento de proteção individual), quando trabalhando em condições de risco. 


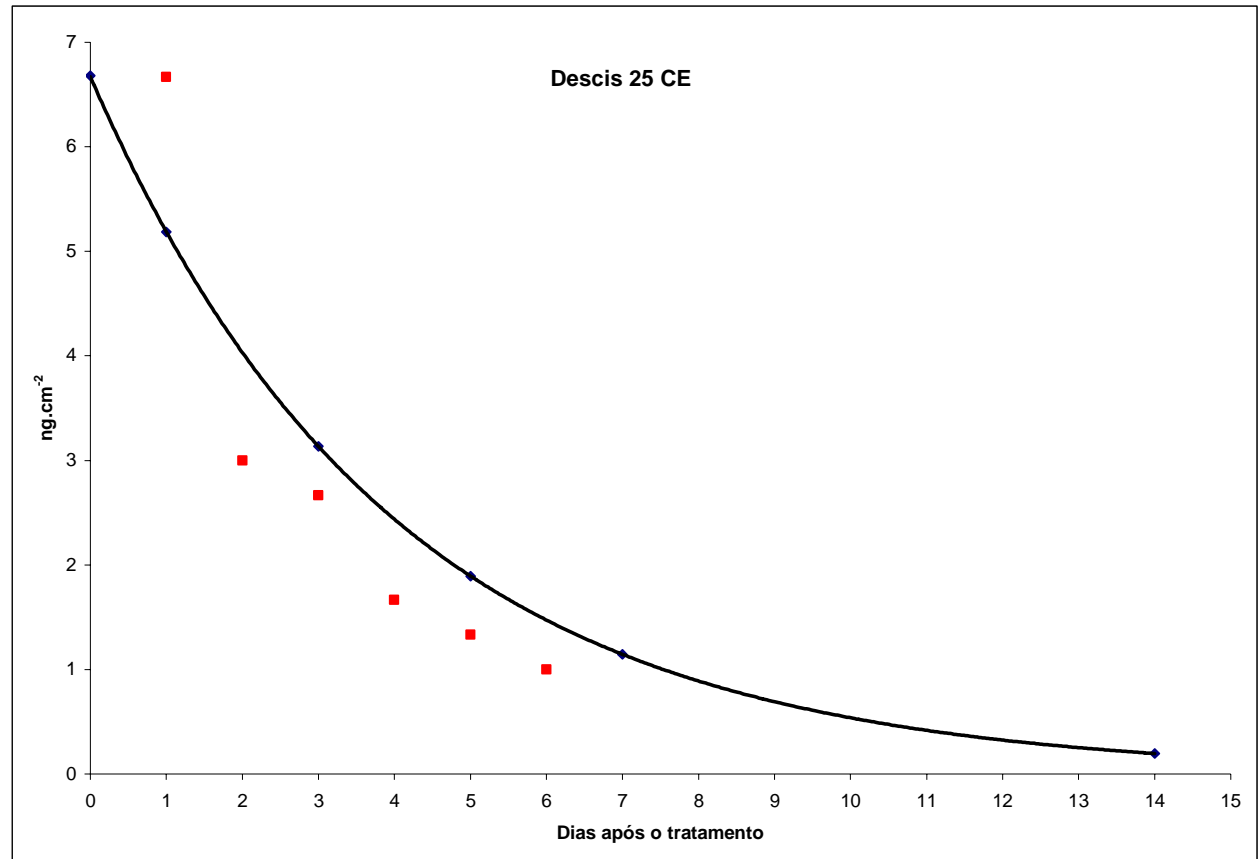

Figura 25 - Resíduo deslocável de deltametrina em folhas de pepino, aplicação de Decis 25 CE (ng.cm²). Equação : Qt $=6,680 \cdot e^{(-t / 3,973)}$

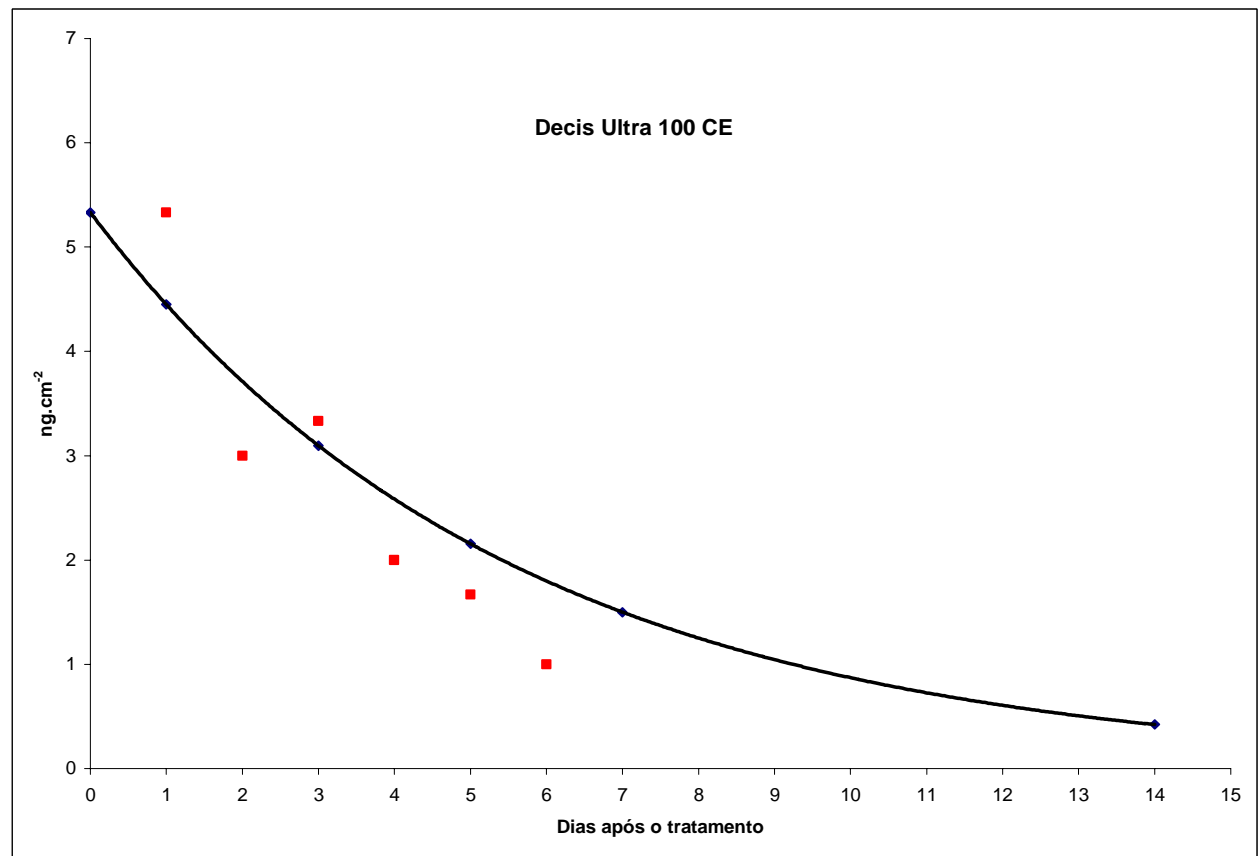

Figura 26 - Resíduo deslocável de deltametrina em folhas de pepino, aplicação de Decis Ultra 100 CE (ng.cm²). Equação : Qt $=5,330 \cdot \mathrm{e}^{(-\mathrm{t} / 5,520)}$ 


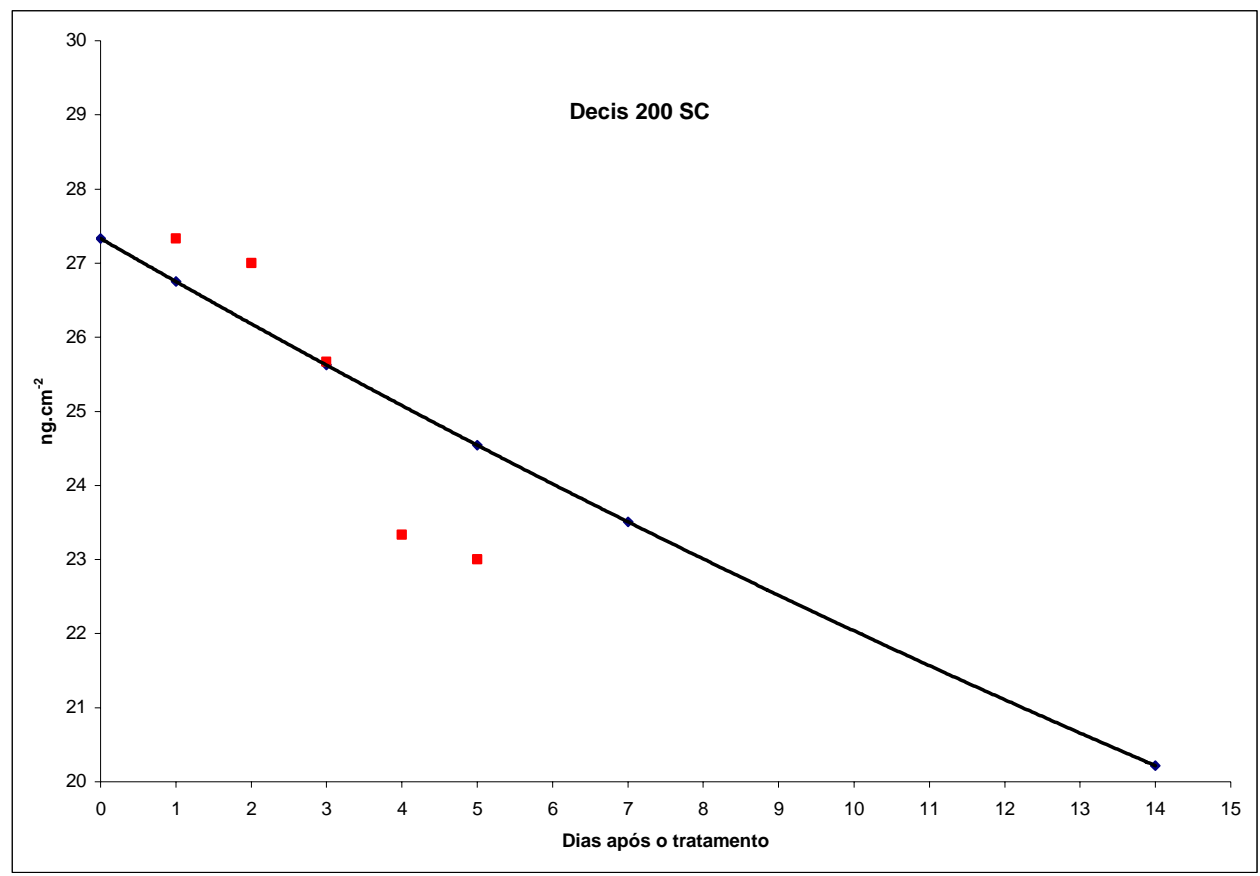

Figura 27 - Resíduo deslocável de deltametrina em folhas de pepino, aplicação de Decis Ultra 100 CE (ng.cm²). Equação : Qt $=27,332 \cdot \mathrm{e}^{(-t / 46,435)}$ 


\subsection{Ação de deltametrina no controle da broca-das-cucurbitáceas, Diaphania nitidalis (Cramer, 1782)}

Os resultados das seis avaliações de infestação da broca-dascucurbitáceas, acham-se nas Tabelas 11 a 16.

Tabela 11. Avaliação da infestação de $D$. nitidalis em pepino (-1 dia após a última aplicação)

\begin{tabular}{lcccc}
\hline \multicolumn{1}{c}{ Formulação } & Número de frutos brocados em 12 & Frutos brocados \\
& A & B & C & $(\%)$ \\
\hline Testemunha & 2 & 3 & 2 & $19 \mathrm{a}$ \\
Decis 25 CE & 0 & 0 & 0 & $0 \mathrm{~b}$ \\
Decis Ultra 100 CE & 0 & 0 & 0 & $0 \mathrm{~b}$ \\
Decis 200 SC & 0 & 0 & 0 & $0 \mathrm{~b}$ \\
\hline
\end{tabular}

Médias seguidas por letras distintas, na coluna, diferem entre si pelo teste de Tukey $(P \leq 0,01)$.

Tabela 12. Avaliação da infestação de $D$. nitidalis em pepino (zero dia após a última aplicação)

\begin{tabular}{lcccc}
\hline \multicolumn{1}{c}{ Formulação } & \multicolumn{1}{c}{ Número de frutos brocados em 12} & Frutos brocados \\
& A & B & C & $(\%)$ \\
\hline Testemunha & 3 & 3 & 3 & $25 \mathrm{a}$ \\
Decis 25 CE & 1 & 0 & 1 & $6 \mathrm{~b}$ \\
Decis Ultra 100 CE & 0 & 1 & 0 & $3 \mathrm{~b}$ \\
Decis 200 SC & 0 & 0 & 0 & $0 \mathrm{~b}$ \\
Médias seguidas por letras distintas, na coluna, diferem entre si pelo teste de \\
Tukey (P $\leq$ 0,01).
\end{tabular}


Tabela 13. Avaliação da infestação de $D$. nitidalis em pepino (1 dia após a última aplicação)

\begin{tabular}{|c|c|c|c|c|}
\hline \multirow{2}{*}{ Formulação } & \multicolumn{3}{|c|}{ Número de frutos brocados em 12} & \multirow{2}{*}{$\begin{array}{c}\text { Frutos brocados } \\
(\%)\end{array}$} \\
\hline & A & B & C & \\
\hline Testemunha & 5 & 3 & 3 & $31 \mathrm{a}$ \\
\hline Decis $25 \mathrm{CE}$ & 0 & 0 & 0 & $0 \mathrm{~b}$ \\
\hline Decis Ultra $100 \mathrm{CE}$ & 0 & 0 & 0 & $0 \mathrm{~b}$ \\
\hline Decis 200 SC & 0 & 0 & 0 & $\mathrm{Ob}$ \\
\hline
\end{tabular}

Médias seguidas por letras distintas, na coluna, diferem entre si pelo teste de Tukey $(P \leq 0,01)$.

Tabela 14. Avaliação da infestação de $D$. nitidalis em pepino (3 dias após a última aplicação)

\begin{tabular}{lcccc}
\hline \multicolumn{1}{c}{ Formulação } & \multicolumn{2}{c}{ Número de frutos brocados em 12 } & Frutos brocados \\
& A & B & C & $(\%)$ \\
\hline Testemunha & 3 & 3 & 3 & $25 \mathrm{a}$ \\
Decis 25 CE & 0 & 1 & 0 & $3 \mathrm{~b}$ \\
Decis Ultra 100 CE & 0 & 0 & 1 & $3 \mathrm{~b}$ \\
Decis 200 SC & 0 & 0 & 0 & $0 \mathrm{~b}$ \\
\hline Médias seguidas por letras distintas, na coluna, diferem entre si pelo teste de \\
Tukey $(\mathrm{P} \leq 0,01)$.
\end{tabular}


Tabela 15. Avaliação da infestação de $D$. nitidalis em pepino (5 dias após a última aplicação)

\begin{tabular}{lcccc}
\hline \multicolumn{1}{c}{ Formulação } & \multicolumn{2}{c}{ Número de frutos brocados em 12 } & Frutos brocados \\
& A & B & C & $(\%)$ \\
\hline Testemunha & 4 & 5 & 4 & $36 \mathrm{a}$ \\
Decis 25 CE & 0 & 0 & 0 & $0 \mathrm{~b}$ \\
Decis Ultra 100 CE & 0 & 0 & 0 & $0 \mathrm{~b}$ \\
Decis 200 SC & 0 & 0 & 0 & $0 \mathrm{~b}$
\end{tabular}

Médias seguidas por letras distintas, na coluna, diferem entre si pelo teste de Tukey $(P \leq 0,01)$.

Tabela 16. Avaliação da infestação de $D$. nitidalis em pepino (7 dias após a última aplicação)

\begin{tabular}{lcccc}
\hline \multicolumn{1}{c}{ Formulação } & \multicolumn{2}{c}{ Número de frutos brocados em 12 } & $\begin{array}{c}\text { Frutos } \\
\text { Brocados } \\
\end{array}$ \\
& A & B & C & $(\%)$ \\
\hline Testemunha & 3 & 4 & 3 & $28 \mathrm{a}$ \\
Decis 25 CE & 1 & 1 & 0 & $6 \mathrm{~b}$ \\
Decis Ultra 100 CE & 0 & 0 & 0 & $0 \mathrm{~b}$ \\
Decis 200 SC & 0 & 0 & 0 & $0 \mathrm{~b}$
\end{tabular}

Médias seguidas por letras distintas, na coluna, diferem entre si pelo teste de Tukey $(P \leq 0,01)$.

Pelos dados apresentados nas Tabelas de 11 a 16, observa-se que 0 inseticida nas três formulações (Decis 25 CE, Decis Ultra 100 CE e Decis 200 SC) foi eficiente no controle da broca-das-cucurbitáceas, durante o período de tomadas das amostras, não diferindo-se estatisticamente entre si. 
Lorini \& Foerster (1987) avaliaram a eficiência de vários inseticidas, entre eles a deltametrina, no controole de $D$. nitidalis ; os autores concluíram que o inseticida não diferiu estatisticamente dos melhores tratamentos. 


\section{CONCLUSÕES}

Considerando-se os resultados experimentais obtidos pode-se concluir que :

- o método analítico utilizado para as analises de resíduos de deltametrina em frutos e folhas de pepino, em solo, bem como os resíduos deslocáveis do inseticida em folhas, é adequado e exeqüível, com limites de quantificação (LOQs) de 0,02 mg. $\mathrm{kg}^{-1}$ (ppm) em fruto, 0,05 mg. $\mathrm{kg}^{-1}$ (ppm) em folhas, $0,01 \mathrm{mg} \cdot \mathrm{kg}^{-1}$ (ppm) em solo e 0,2 $\mathrm{ng} \cdot \mathrm{cm}^{-2}$ para resíduos deslocáveis em folhas;

- os resíduos de deltametrina no fruto, embora em baixos níveis, encontravam-se acima do LMR de 0,03 mg. $\mathrm{kg}^{-1}$, mesmo um dia após o término do intervalo de segurança (2 dias), para as formulações Ultra 100 CE e SC, sendo maiores nesta última;

- $\quad$ o período de 7 dias foi suficiente para dissipação dos resíduos, não se caracterizando, após decorrido este, sobreposições das aplicações nos frutos;

- a degradação dos resíduos de deltametrina nos frutos foi de 2 vezes para qualquer tipo de formulação no período de tomada das amostras, sem evidenciar grande importância de chuvas nessa dissipação;

- nas folhas, os resíduos resultantes das aplicações da formulação SC foram sempre maiores do que os de ambas CE (10-20 vezes), durante todo o período de tomada das amostras; 
- os resíduos nas folhas foram sempre maiores do que nos frutos (15-80 vezes); o fato pode ser explicado em razão da maior superfície especifica que elas possuem em relação aos frutos; entretanto, a degradação, em todos os tratamentos, foi maior nelas do que neles, para as formulações CE (6-12 vezes) e semelhante para a SC (2 vezes);

- $\quad$ nas folhas houve sobreposição dos resíduos de deltametrina originados das três formulações, especialmente os da SC (16 vezes maiores do que as formulações CE);

- no solo, os resíduos de deltametrina foram baixos $\left(0,01-0,05 \mathrm{mg} \cdot \mathrm{kg}^{-1}\right)$, no período de colheita das amostras;

- os níveis de resíduos resultantes da formulação SC, no solo, foram semelhantes aos das CE, e mostraram tendência de baixa dissipação, fato explicado pela baixa solubilidade da deltametrina em água;

- os resíduos deslocáveis de deltametrina nas folhas foram muito mais elevados quando derivados das aplicações em SC, do que os das formulações CE (4-20 vezes), e se mostraram comparativamente maiores mais para o final do período de tomadas das amostras;

- os valores de meias-vida dos resíduos deslocáveis nas folhas foram de 2,8; 3,8 e 32,2 dias, respectivamente para as formulações Decis 25 CE, Decis Ultra 100 CE e Decis 200 SC;

- $\quad$ esses valores de meias-vida indicam maior persistência dos resíduos decorrentes das aplicações da formulação SC, comparados com os das aplicações dos CE, comprovados pelo fato de que as dissipações foram, respectivamente de apenas 1,8 vez no tratamento SC e de 7,0 e 5,0 nos de formulação CE (7,0 vezes no Decis 25 CE e 5,0 no Decis Ultra 100 $\mathrm{CE})$;

- $\quad$ o inseticida, nas formulações em que foi aplicado, foi eficiente no controle da broca-das-cucurbitáceas, durante todo o período de avaliação. 


\section{REFERÊNCIAS BIBLIOGRAFICAS}

AGÊNCIA NACIONAL DE VIGILÂNCIA SANITÁRIA. Deltametrina http://www4.anvisa.gov.br/AGROSIA/asp/frm_dados_ingrediente.asp? iVarAux=1\&Codlng=124 (15 Jun. 2004)

ANDERSSON, A.; PALSHEDEN, H. Multi-residue method for the analysis of pesticides in fruit and vegetables using ethyl acetate extraction, GPC cleanup and GC determination. In: NATIONAL FOOD ADMINISTRATION. Pesticide analytical in Sweden. Uppsala, p. 9-41, 1998, (Rapport, 17).

ANDREI, E. Compêndio de defensivos agrícolas: guia prático de produtos fitossanitários para uso agrícola. 6. ed. São Paulo: Organização Andrei, 1999. 672p.

ANTONIOUS, G. F.; BYERS, M. E.; KERST, W.C. Residue levels of pyrethrins and piperonyl butoxide in soil and runoff water. Journal Environmental. Journal of Environmental Science Health, Part B, v. 32, n. 5, p. 621-644, 1997.

AWASTHI, M. D. Persistence pattern and safety evaluation of synthetic pyrethroids on eggplant. Indian Journal of Agricultural Sciences, v. 55, n.9, p. 600-603, 1985. 
BALWINDER, S.; PARM, P. S.; RAMINDERJIT, S. B.; KALRA, R. L. Residues of synthetic pyrethroid insecticides on tomato under sub-tropical conditions of Punjab, Índia. Bulletin of Environmental Contamination and Toxicology, v. 43, n 5, p. 733-736, 1989. /Resumo em CAB Abstract, v. 18, n. 2, p. 219-, 1990-1991/

BARBOSA, A. A proteção das hortaliças com piretróides sintéticos. Horticultura Brasileira, v.2, n.1, p. 3-5, 1984.

BATISTA, G.C. de; STAMPER, J. H.; NIGG, H. N.; KNAPP, J. L. Dislodgeable residues of carbophenotion in Florida Citrus: Implications for safe worker reentry. Bulletin of Environmental Cotamination and Toxicology, v. 35, p. 213-221, 1985.

BEVENUE, A. The "bioconcentration" aspects of DDT in the environmental. In: GUNTHER, F.A.; GUNTHER, J. D. Residues of pesticides and other contaminants in the total environment. Residue Reviews, v. 61, p. 37-112, 1976.

BOCQUET, J.C.; L'HOTELLIER, M. The effect of deltamethrin on the Aquatic Environment. Pesticide Science, v. 16, p.198, 1985.

BOSALL, J. L. Measurement of occupational exposure to pesticide. In: TURNBULL, G. I. Occupational hazards of pesticide use. London: Taylor \& Francis, 1985. p. 13-33.

BRASIL. Ministério da Agricultura. Legislação federal de agrotóxicos e afins. Brasília: Ministério da Agricultura, Departamento de Defesa e Inspeção Vegetal, 1998. 184p. 
BROUWER, R.; BROUWER, D. H.; MARQUAT, J.; TIJSSEN, S. C. H. A.; VREEDE, J. A. F.; MIK, G. de; HEMMEN, J. J. Dermal exposure to pesticide during reentry in the flower culture in greenhouses. In: TNO MEDICAL BIOLOGICAL LABORATORY. Annual Report - 1990. s.l., 1990. p. 181-184.

CABRAS, P.; CABITZA, F.; MELONI, M.; PIRISI, F. M. Behavior of some pesticide residues on greenhouse tomatoes. 2. fungicides, acaricides, and insecticides. Journal of Agricultural and Food Chemistry, v. 33, p. 935937, 1985.

CARVALHO, S. P. L. de. Resíduos de deltametrina e de carbaril em diferentes sistemas de condução na cultura do tomate estaqueado (Lycopersicon esculentum Mill) e eficiência no controle da broca-pequena-do-fruto (Neoleucinodes elegantalis) (Guenée: 1854) (Lepidóptera: Crambidae) Piracicaba, 2003. 51p. Dissertação (Mestrado) - Escola Superior de Agricultura "Luiz de Queiroz", Universidade de São Paulo.

CANTLIFFE, D. J.; PHATAK, S. C. Plant population studies with pickling cucumbers grown for once-over harvest. Journal of the American Society for Horticultural, v. 100, n. 5, p. 464-466, 1975.

CHAPMAN, R. A.; TOLMAN, J. H.; HARRIS, C. R.; COLE, C. Persistence of five pyrethroid insecticides in sterile and natural, mineral and organic soil. Bulletin of Environmental Contamination and Toxicology, v. 26, n 4, p.513-519, 1981.

COFFIN, D.F. Residues of parathion methyl, parathion, EPN and their oxons in Canadian fruits and vegetables. Residues Reviews, v. 7, p. 61-73, 1964. 
COLE, L. M.; CASIDA, J. E.; RUZO, L. O. Comparative degradation of the pyrethroids tralomethrin, tralocythrin, deltamethrin, and cypermethrin on cotton and bean foliage. Journal of Agricultural and Food Chemistry, v.30, p. 916-920, 1982.

CORNELL UNIVERSITY. The Pesticide Management Education Program at Cornell University 2000. Disponível : http://pmep.cce.cornell.edu/. (03 Jan. 2001).

DELGADO, I. F.; PAUMGARTTEN, F. J. R. Intoxicações e uso de pesticidas por agricultores do Município de Paty do Alferes, Rio de Janeiro, Brasil. Caderno de Saúde Pública, v. 20, n. 2, p. 180-186, 2004.

DEMATTÊ, M. E. S. P. Comportamento de cultivares de pepino (Cucumis sativus L.) em duas épocas de semeadura. Piracicaba, 1978. 109p. Dissertação (Mestrado) - Escola Superior de Agricultura "Luiz de Queiroz", Universidade de São Paulo.

DIEHR, H. J.; GALLENKAMP, B.; JELICH, K.; LANTZSCH, R.; AND SHIOKAWA, K. Synthesis and chemical-physical properties of the insecticide imidacloprid (NTN 33893). Pflanzenschutz-Nachrichten-Bayer, v.44, n.2, p.107-112, 1991.

DUPUIS, G. Pesticide residues in citrus. CIBA-GEIBY AGROCHEMICALS. Citrus, v.1, p. 91-98, 1975.

DURHAM, W. F.; WOLFE, H. R. Measurement of the exposure of workers to pesticides. Bulletin of the World Health Organization, v.26, p. 75-91, 1962. 
EBELING, W. Analysis of the basec process involved in the deposition, degradation, persistance, and effectiveness of pesticides. Residues Reviews, v.3, p.35-163. 1963.

EVARISTO, A. Resíduos deslocáveis de metamidofós em cultura estaqueada de tomate (Lycopersicon esculentum Mill). Piracicaba, 1994. 55p. Dissertação (Mestrado) - Escola Superior de Agricultura "Luiz de Queiroz", Universidade de São Paulo.

EXTOXNET: Extension Toxicology Network. Imidacloprid 1997. http://ace.orst.edu/cgi-bin/mfs/01pips/imidaclo.htm. (03 Jan.2001).

FERNANDEZ - ALBA, A. R.; VALVERDE, A.; AGUERA, A.; CONTRERAS, M.; $\mathrm{CHIRON}, \mathrm{S}$. Determination of imidacloprid in vegetables by high-performace liquid chromatography with diode-array detection. Journal of Chromatography, A, v.721, p.97-105. 1996.

FERST, J. C. Resíduos de clorpirifós e fenitrotion em casca e polpa de pepino "Caipira" determinados por cromatografia em fase gasosa. Piracicaba, 1991. 71p. Dissertação (Mestrado) - Escola Superior de Agricultura "Luiz de Queiroz", Universidade de São Paulo.

FNP CONSULTORIA \& COMÉRCIO. Agrianual 2004: anuário da agricultura brasileira. São Paulo, 2004. p. 404-406: hortaliças.

FRANÇA, H. F.; CORDEIRO, C. M. T.; GIORDANO, L. B. Controle da broca das cucurbitáceas em pepino. Horticultura Brasileira, v.3, n.2, p. 47-53, 1985. 
FRANK, R.; JOHNSON, K.; BRAUN, H. E. Monitoring, soil, stream and fish for aerial drift of permethrin. Environmental Monitoring and Assessment, v.16, p. 127-150, 1991.

FRENICH, A. G.; GONZÁLEZ, F. J. E.; VIDAL, J. L. M.; VÁZQUEZ, P. P.; SÁNCHEZ, M. M. Determination of imidacloprid and its metabolite 6chloronicotinic acid in greenhouse air by high-performace liquid chromatography with diode-array detection, Journal of Chromatography, A, v.869, p.497-504. 2000.

GALLO, D; NAKANO, O.; NETO, S. S.; CARVALHO, R. P. L.; BAPTISTA, G. C.; FILHO, E. B.; PARRA, J. R. P.; ZUCCHI, R. A.; ALVES, S. B.; VENDRAMIM, J. D.; MARCHINI, L. C.; LOPES, J. R. S.; OMOTO, C. Entomologia agrícola. Piracicaba: FEALQ, 2002. 920 p.

GIANNOTTI, O. O problema do controle químico e os resíduos de inseticidas. In: CONGRESSO LATINOAMERICANO DE ENTOMOLOGIA, 1., Cuzco, 1971. Anais. p. 47-54.

GILES, D.K.; BLEWETT, T. C. Effects of conventional and reduced-volume, charged-spray application techniques on dislodgeable foliar residue of captan on strawberries. Journal of Agricultural and Food Chemistry, v. 39, n. 9, p.1646-1651, 1991.

GUNTHER, F. A.; BLINN, R.C. Analysis of insecticides and acaricides. New York: Interscience, 1955. 696 p.

GUNTHER, F. A. Insecticides residues in California citrus fruit and products. Residues Reviews, v.28, p.1-127, 1969. 
GUNTHER, F. A.; JEPPSON, L. R. Residues of p-chlorophenyl-pchlorobenzenosulfanate (compound K-6451) on and in lemon and oranges. Journal of Economic Entomology, v. 47, n. 6, p. 1027-1032, 1954.

GUNTHER, F.A.; IWATA, Y.; CARMAN, G. E.; et al. The citrus reentry problem: research on its causes and effects, and approaches to its minimization. Residue Reviews, v. 67, p. 1-139, 1977.

GUNTHER, F. A.; WESTLAKEK, W. E.; BARKLEY, J. H. Establishing dislodgeable pesticide residues on leaf surfaces. Bulletin of Environmental Cotamination and Toxicology, v. 9, p. 243-249, 1973.

HASCOËT, M.; ANDRÉ, L. Détermination des résidus de décaméthrine présents dans lês végétaux et les sols traités. Phytiatrie - Phytopharmacie, v. 27, p. 85-89, 1978.

HAYES, J. W. Recognized and possible exposure to pesticides. Toxicology of pesticides. Baltimore: Willians \& Wilkins, 1975. 580p.

HEMMEN, J. J. van. Modelling in exposure assessment of pesticides for registration purposes. The Annals of Occupational Hygiene, v. 37, p. 541563, 1993.

HILL, B. D. Persistence of deltamethrin in a Lethbridge sandy clay loam. Journal of Environmental Science Health, Part B, v. 18, p. 691-703, 1983

HILL, B. D.; INABA, D. J.; SCHAALJE, G.B. Persistence of deltamethrin in baled alfafa hay. Journal of Agricultural and Food Chemistry, v. 40, p. 24932496, 1992. 
INTERNATIONAL UNION OF PURE AND APPLIED CHEMISTRY. Glossary of terms relating to the chemistry of agrochemicals. 1996. http://www.iupac.org/reports/1996/6805holland/d1.html\#dislodgeable May. 2004).

ISHII, Y.; KOBORI, I.; ARAKI, Y.; KUROGOCHI, S.; IWAYA, K.; and KAGABU, S. HPLC determination of the new insecticide imidacloprid and its behavior in rice and cucumber. Journal of Agricultural and Food Chemistry, v.42, n.12, p.2917-2921. 1994.

KAGABU, S.; MEDEJ, S. Stability comparison of imidacloprid and related compounds under simulated sunligh, hydrolysis conditons, and to oxygen. Bioscience, Biotechnology and Biochemistry, v.59, n.6, p.980-985. 1995.

KRAPAC, I. G.; ROY, W. R.; SMYTH. C. A.; BARNHART, M. L. Occurrence and distribution of pesticides in soil at agrichemical facilities in Illinoius. Journal of Soil Contamination, v. 4, n. 3, p. 209-226,1995.

KREUGER, J.; PETERSON, M. LUNDGREN, E. Agricultural inputs of pesticide residues to stream and pond sediments in a small catchment in southern Sweden. Bulletin of Environmental Contamination and Toxicology, v. 62, n 1, p. 55-62, 1999.

LEICHT, W. Imidacloprid: a chloronicotinyl insecticide biological activity and agricultural significance. Pflanzenschutz-Nachrichten-Bayer, v.49, n.1, p.71-84. 1996. 
LORINI, I.; FOERSTER, L. A. Ocorrência e efeito de inseticidas sobre a broca dos frutos (Diaphania nitidali, Stoll), (Lepidóptera:Pyralidae) na cultura do pepino (Cucumis sativus L.). Anais da Sociedade Entomológica do Brasil, Porto Alegre, v.16, n.1, p. 145-153, 1987.

LUCAS, M. B. Resíduos de fenitrotion em frutos, folhas, solo e água de irrigação em cultura de berinjela (Solanum melongena L.) Piracicaba, 1998. 130p. Tese (Doutorado) - Escola Superior de Agricultura "Luiz de Queiroz", Universidade de São Paulo.

LUKE, M. A.; MASUMOTO, H. T.; CAIRNS, T.; HUNDLEY, H. K. Levels and incidence of pesticides residues in various foods and animal feeds analysed by the Luke multiresidue methodology for fiscal years 1982-1986. Journal of Association of Official Analytical Chemistry, v.71, n.2, 415-433, Mar./Apr. 1988.

MAcCATTHY, J. F. Reentry: an industrial viewpoint. In: PLIMMER, J. R., (Ed.). Pesticide residues and exposure. Washington: American Chemical Society, 1982. p.183-187.

MACHADO NETO, J. G. Quantificação e controle da exposição dérmica de aplicadores de agrotóxicos em culturas estaqueadas de tomate, na região de Cravinhos, SP. Jaboticabal, 1990. 112 p. Tese (Doutorado) - Faculdade de Ciências Agrárias e Veterinárias; Universidade Estadual Paulista "Júlio de Mesquita Filho",.

MACHADO NETO, J. G. Ecotoxicologia de agrotóxicos. Jaboticabal, FCAV FUNEP, 1991. $49 \mathrm{p}$. 
MAGUIRE, R. J. Chemical photochemical isomerization of deltamethrin. Journal of Agricultural and Food Chemistry, v. 38, p. 1613-1617, 1990.

MAGUIRE, R. J. Kinetics of Pesticide Volatilization from the surface of water. Journal of Agricultural and Food Chemistry, v. 39, p. 1674-1676, 1991.

MAGUIRE, R. J.; CAREY, J. H.; HART, J. H.; TKACZ, R. J.; LEE, H. B. Persistence and fate of deltamethrin sprayed on a pond. Journal of Agricultural and Food Chemistry, v. 37, p. 1153-1159, 1989.

MULLA, M. S.; NAVVAB-GOJRATI, H. A.; DARWAZEH, H. A. Toxicity of mosquito larvicidal pyrethroids of four species of freshwater fishes. Environmental Entomology, v. 7, p. 428-430, 1978.

NIGG, H. N.; ALLEN, J. C.; KING, R. W. Behavior of parathion residues in the Florida "Valencia" orange agroecosysterm. Journal of Agricultural and Food Chemistry, v. 27, n. 3, p. 578-582, 1979.

NIGG, H. N.; STAMPER, J. H. Biological monitoring for pesticide dose determination. Historical perspectives, current practices, and new approaches. In: Wang, R. G. M.; FRANKLIN, C. A.; HONEYCUTT, R. C.; REINERT, J. C.. (Ed.). Biological monitoring for pesticide exposure; measurement, estimation, and risk reduction. Washington: American Chemical Society, 1989. p. 6-27. (ACS Symposium Series, 382).

NIGG, H. N.; STAMPER, J. H.; KNAAK, J. B. Leaf, fruit, and soil surface residues of carbosulfan and its metabolites in Florida citrus groves. Journal of Agricultural and Food Chemistry, v. 32, n. 1, p. 80-85, 1984b. 
NIGG, H. N.; STAMPER, J. H.; QUEEN, R. M. The development and use of a universal model to predict tree crop harvester pesticide exposure. American Industrial Hygiene Association Journal, v. 45, n. 3, p. 182-186, 1984a.

OLIVEIRA-SILVA, J. J.; ALVES, S. R.; MAUER, A. et al. Influência de fatores socioeconômicos na contaminação por agrotóxicos, Brasil. Revista de Saúde Pública, v. 35, n. 2, p. 130-135, 2001.

OVIEDO, M. T. P.; TOLEDO, M. C. F.; VICENTE, E. Resíduos de agrotóxicos piretróides em hortaliças. Revista de Ecotoxicologia e Meio Ambiente, v. 13, Jan/Dez. 2003.

PEREIRA, D. E. D. Coleta de amostras para análises de resíduos de pesticidas. Vitória: EMCAPA, 1987. 45p. (EMCAPA. Documentos, 39).

PLACKE, F. J.; WEBER, E. Method of determining imidacloprid residues in plant materials. Pflanzenschutz-Nachrichten-Bayer, v.46, n.1, p. 109-182. 1993.

POPENDORF, W. J.; LEFFINGWELL, J. T. Regulation OP pesticide residues for farmworker protection. Residue Reviews, v. 82, p. 125-201, 1982.

POPENDORF, W. J. Advances in the unified field model for reentry hazards. In: HONEYCUTT, R. C.; ZWEIG, G.; RAGSDALE, N. N., (Ed.). Dermal exposure related to pesticide use: dicussion of risk assessment. Washington: American Chemical Society, 1985. p.324-340.

PREM, C.; KASHYAP, N. P.; JITENDER, K.; CHAND, P.; KUMAR, J. Residue dynamics of some insecticides on / in tomato, Lycopersicon esculentum Mill. Pest Management and Economic Zoology, v. 7, n. 2, p. 131-135, 1999. /Resumo em CAB Abstracts, v. 7, n. 2, p. 131, 2000/2002/ 
RAHA, P.; BANERJEE, H.; DAS, A. K.; ADITYACHAUDHURY, N. Persistence kinetics of endosulfan, fenvalerate, and decamthrin in ando $\mathrm{n}$ eggplant (Solanum melongena L.) Journal of Agricultural and Food Chemistry, v.41, n. 6, p. 923-928, 1993.

RIBEIRO, C. S. C.; BRUNE, S.; REIFSCHNEIDER, F. J. B. Cultivo da berinjela (Solanum melongena L.). Instruções Técnicas da Embrapa Hortalicas, n.15, 24p. 1998.

RIPLEY, B. D.; RITCEY, G. M.; HARRIS, C. R.; DENOMMÉ, M. A.; BROWN, P. D. Pyrethroid insecticide residues on vegetable crops. Pest Management Science, v. 57, p. 683-687, 2001.

ROUCHAUD, J.; MEYER, J. A. New trends in the studies about the metabolism of pesticides in plants. Residue Reviews, v. 82, p. 1-35, 1982.

RÜEGG, E. F.; PUGA, F. R.; SOUZA, M. C. M. de; ÚNGARO, M. T. S.; FERREIRA, M. das S.; YOKOMIZO, Y.; ALMEIDA, W. F.; SAN MARTIN, P. O impacto dos agrotóxicos sobre o ambiente, a saúde e a sociedade. 2.ed. São Paulo: Ícone Editora, 1991, 94 p.

RUZO, L. O.; HOLMSTEAD, R. L.; CASIDA, J. E. Pyrethroid photochemistry: Decamethrin. Journal of Agricultural and Food Chemistry, v. 25, p. 13851394, 1977.

SALDIVAR, E. L. Pesticide usage and residues on vegetables, grains and fruits. Philippine Journal of Crop Science, v. 23, n. 1, p. 37, 1998. /Resumo em AGRIS, 1997/ 
SASSAKI, H. M.; KIMOTO, T. Teste de inseticidas em cultura de pepino (Cucumis sativus L.). Horticultura Brasileira, v.4, n.1, p. 70, 1986.

SCARPELLINI, J. R. Seleção hospedeira, danos simulados e controle da mosca minadora de folhas Liriomyza huidobrensis (Blanchard, 1926) com produtos químicos fisiológicos na cultura do pepino Cucumis sativus L. Piracicaba, 1989. 102p. Dissertassão (Mestrado) - Escola Superior de Agricultura "Luiz de Queiroz", Universidade de São Paulo.

SINGH, B.; GUPTA, A. Monitoring of pesticide residues in farmgate and market samples of vegetables in a semiarid, irrigated area. Bulletin of Environmental Contamination and Toxicology, v. 68, p. 747-751, 2002.

SPENCER, W. F.; CLIATH, M. M.; DAVIS, K. R.; SPEAR, R. C.; POPENDORF, W. J. Persistence of parathion and its oxidation to paraoxon on the soil surfaces as related to worker reentry into treated crops. Bulletin of Environmental Contamination and Toxicology, v. 14, n. 3, p. 265-272, 1975.

SPENCER, E. Y. The significance of plant metabolites of insecticide residues. Residue Reviews, v. 9, p. 153-168, 1965.

SPENCER, W. F.; KILGORE, W. W.; IWATA, J.; KNAAK, J. B. Worker reentry into pesticide-treated crops. II. Procedures for the determination of pesticide residues on the soil surface. Bulletin of Environmental Cotamination and Toxicology, v. 18, p. 656-662, 1977.272, 1977.

SPYNU, E. I. Predicting pesticide residues to reduce crop contamination. Reviews of Environmental Contamination and Toxicology, v.109, p.89107, 1989. 
THAPINTA, A.; HUDAK, P. F. Pesticide use and residual occurrence in Thailand. Environmental Monitoring and Assessment, v. 60, p. 103-114, 2000.

TOMLIN, C. World compendium the pesticide manual: incorporanting the agrochemicals handbook. 10.ed. Cambridge: Britsh crop Protection Council; Royal Society of Chemistry, 1995. 1341p.

TURNBULL, G. J.; SANDERSON, D. M.; CIROME, S. J. Exposure to pesticides during application. In: TURNBULL, G. J. Occupational hazards of pesticide use. London: Taylor \& Francis, 1985. p. 35-49.

VALVERDE GARCIA, A.; GONZALES PRADAS, E.; AGUILERA DEL REAL, A.; URENA AMATE, M. D.; CAMACHO FERRE, F. Determination and degradation study of chlorothalonil residues in cucumbers, peppers and cherry tomatoes. Acta Analytica Chimica, v. 276, n. 1, p. 15-23, 1993.

VILCHEZ, J. L.; EL-KHATTABI, R,; BLANC, R.; NAVALÓN, A. Photochemicalfluorimetric method for the determination of the insecticide imidacloprid in water samples. Analytica Chimica Acta, v.371, p.247-253. 1998.

VILLAS BÔAS, G. L. Métodos de controle de pragas em hortaliças. Horticultura Brasileira, v.7, n.1, p. 3-6, 1989.

WESTCOTT, N. D.; REICHLE, R. A. Deltamethrin residues on Saskatoon berries. Journal of Agricultural and Food Chemistry, v. 41, p. 2153-2155, 1993. 
WESTWOOD, F.; BEAN, K. M.; DEWAR, A. M.; BROMILOW, R. H. \& CHAMBERLAIN, K. Movement and persistence of $\left[{ }^{14} \mathrm{C}\right]$ imidacloprid in sugar-beet plants following application to pelleted sugar-beet seed. Pesticide Science, v.52, p97-103. 1998.

WINTERLIN, W. L.; KILGORE, W.W.; MOURER, C. R.; SCHOEN, S. R. Worker reentry studies for captan applied to strawberries in California. Journal of Agricultural and Food Chemistry, v. 32, n. 3, p. 664-672, 1984.

WOLFE, H. R.; ARMSTRONG, J. F.; STALFF, D.C.; COMER, S.W. Exposure of spraymen to pesticide. Archives Environmental Health, v. 25, p. 29-31, 1972.

World Health Organization. Deltamethrin: environmental health criteria 97. http://www.inchem.org/documents/ehc/ehc/ehc97.htm (12 May. 2004)

YAMAMOTO, I. Neonicotinoids mode of action and selectivity. Agrochemicals - Japan, n.68, p.14-15, 1996.

ZHANG, L. Z.; KHAN, S. U.; AKHTAR, M. H.; IVARSON, K. C. Persistence, degradation, and distribution of deltametrin in an organic soil under laboratory conditions. Journal of Agricultural and Food Chemistry, v. 32, p. 12071211, 1984.

ZITKO, V.; MCLEESE, S. W.; METCALFE, C. D.; CARSON, W. G. Toxicity of permethrin, decamethrin, and related pyrethroids to salmon and lobster. Bulletin of Environmental Contamination and Toxicology, v. 21, p. 338343, 1979. 
ZWEIG, G.; GAO, R.; POPENDORF, W. Simultaneous dermal exposure to captan and benomyl by strawberry harvesters. Journal of Agricultural and Food Chemistry, v. 31, n. 5, p. 1109-1113, 1983.

ZWEIG, G.; GAO, R.; WITT, J. M.; POPENDORF, W. J. Exposure of strawberry harvesters to carbaryl. In: HONEYCUTT, R. C.; ZWEIG, G.; RAGSDALE, N. N. (Ed.). Dermal exposure related to pesticide use: dicussion of risk assessment. Washington: American Chemical Society, 1985. p.124-138. 
APÊNDICE 
Dados Climatológicos relativos ao período de duração do experimento.

\begin{tabular}{|c|c|c|c|c|c|}
\hline \multirow[t]{2}{*}{ Aplicação } & \multirow[t]{2}{*}{ Data } & \multirow{2}{*}{$\begin{array}{c}\text { Dias após } \\
\text { a } \\
\text { aplicação }\end{array}$} & \multicolumn{2}{|c|}{$\begin{array}{c}\text { Temperatura } \\
\left({ }^{\circ} \mathrm{C}\right)\end{array}$} & \multirow{2}{*}{$\begin{array}{l}\text { Precipitação } \\
\text { Atmosférica } \\
(\mathrm{mm})\end{array}$} \\
\hline & & & Máxima & Mínima & \\
\hline \multirow[t]{7}{*}{$1^{a}$} & $24 / 12 / 2003$ & & 19 & 16 & - \\
\hline & $25 / 12 / 2003$ & & 23 & 15 & - \\
\hline & $26 / 12 / 2003$ & & 20 & 18 & - \\
\hline & $27 / 12 / 2003$ & & 28 & 18 & - \\
\hline & $28 / 12 / 2003$ & & 28 & 16 & - \\
\hline & $29 / 12 / 2003$ & & 29 & 17 & - \\
\hline & $30 / 12 / 2003$ & & 28 & 18 & 8,1 \\
\hline \multirow[t]{8}{*}{$2^{a}$} & $31 / 12 / 2003$ & & 28 & 21 & - \\
\hline & 01/1/2004 & & 19 & 19 & 21 \\
\hline & $02 / 1 / 2004$ & & 18 & 15 & - \\
\hline & 03/1/2004 & & 23 & 15 & - \\
\hline & 04/1/2004 & & 24 & 15 & - \\
\hline & 05/1/2004 & & 27 & 17 & - \\
\hline & 06/1/2004 & & 29 & 16 & - \\
\hline & 07/1/2004 & -1 & 22 & 18 & 46,5 \\
\hline \multirow[t]{15}{*}{$3^{a}$} & 08/1/2004 & 0 & 19 & 16 & 1,5 \\
\hline & 09/1/2004 & 1 & 26 & 19 & 14,8 \\
\hline & 10/1/2004 & & 28 & 16 & 2,3 \\
\hline & $11 / 1 / 2004$ & 3 & 30 & 16 & 2,8 \\
\hline & $12 / 1 / 2004$ & & 26 & 18 & - \\
\hline & $13 / 1 / 2004$ & 5 & 27 & 18 & - \\
\hline & $14 / 1 / 2004$ & & 29 & 16 & - \\
\hline & $15 / 1 / 2004$ & 7 & 32 & 19 & - \\
\hline & $16 / 1 / 2004$ & & 26 & 18 & 26,1 \\
\hline & $17 / 1 / 2004$ & & 24 & 15 & 0,2 \\
\hline & $18 / 1 / 2004$ & & 23 & 16 & - \\
\hline & $19 / 1 / 2004$ & & 27 & 14 & - \\
\hline & 20/1/2004 & & 24 & 16 & - \\
\hline & 21/1/2004 & & 19 & 17 & - \\
\hline & 22/1/2004 & 14 & 24 & 18 & 16,8 \\
\hline$m \pm d p$ & & & $25,0 \pm 3,8$ & $16,9 \pm 1,6$ & \\
\hline Total & & & & & 140,1 \\
\hline
\end{tabular}

